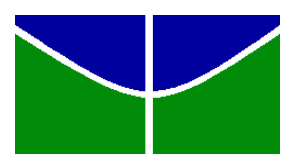

Universidade de Brasília

Instituto de Ciências Biológicas

Departamento de Biologia Celular

Programa de Pós-Graduação em Biologia Molecular

CALLIANDRA MARIA DE SOUZA SILVA

\title{
CARACTERIZAÇÃO DAS BASES MOLECULARES DA RESPOSTA IMUNE INATA DO HOSPEDEIRO MURINO À PARACOCCIDIOMICOSE
}

BRASÍLIA-DF 
Universidade de Brasília

Instituto de Ciências Biológicas

Departamento de Biologia Celular

Programa de Pós-Graduação em Biologia Molecular

CALLIANDRA MARIA DE SOUZA SILVA

\section{CARACTERIZAÇÃO DAS BASES MOLECULARES DA RESPOSTA IMUNE INATA DO HOSPEDEIRO MURINO À PARACOCCIDIOMICOSE}

Tese de Doutorado apresentada ao Programa de Pós-graduação em Biologia Molecular, do Instituto de Ciências Biológicas da Universidade de Brasília.

Orientadora: Profa. Dra. Ildinete Silva Pereira Co-orientadora: Profa. Dra. Anamélia Lorenzetti Bocca 


\section{DEDICATÓRIA}

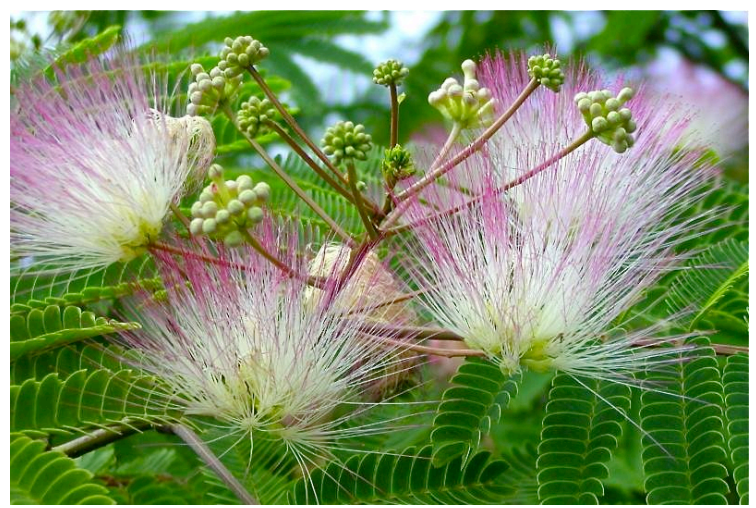

Dedico este trabalho a todas as pessoas que marcaram minha jornada, em especial minha família. 


\section{AGRADECIMENTO}

É difícil saber com agradecer a todos que me ajudaram, me espiraram e guiaram para terminar esta jornada conhecida como o Doutorado. Afim, como tudo requer esforço e dedicação, teve muitos altos e baixos. Mudança de laboratório, aprender a trabalhar com camundongos (biotério, matrizes de cruzamento, manter-los saudável e modelos de experimento), lei de Murphy, caos inerente de trabalhar com animais, além enfermidades que atrapalhou meus últimos anos do doutorado mas agora estou mais recuperada. Sem ajuda e a guia de grupo de pessoas pra lá de especiais nessa jornada talvez nunca tivesse concluído esta jornada.

Um lugar de honra pertence sempre à minha família, os meus, que desde que era um pingo de gente sempre estiveram ao meu lado, nos bom e maus momentos, nos momentos de orgulho e de presepadas. Sempre acreditando em me, e me apoiando a puxar meus limites. Mãe, Pai e Chu: muito obrigado! Os amos muitíssimo. Chu, o período de tempo que esteve presente comigo não tem como agradecer. Minhas queridíssimas avós, Severina e Elpídia, vocês são demais. Seus os conselhos e suas filosofias são meu compasso moral.

Fátima Guerra e Ivan Sérgio, minha família de Brasília. Durante o mestrado e logo o doutorado, vocês foram a minha pedra. Me darem abrigo e orientações, um lugar em sua família, à qual senti pertencer. Os jantares e os café das manhas sempre foram para mim mágicos. Muito obrigada!

Ildinete (Al), minha orientadora, quem seria eu agora sem seu apoio. Não tenho palavras para agradecer o que fez por mim. Você continua sendo o meu Norte e um exemplo de pessoa que quero ser, tanto na vida pessoal como na vida professional. Sua paciência, humanismo e compreensão permitiu chegar aonde cheguei, e cumprir com minhas responsabilidades e estabilizar-me. Obrigada! Obrigada! Obrigada!

Também quero agradecer a minha co-orientadora Anamélia. Sem sua experiência e guia, tanto nos cuidados do camundongos quanto nos procedimentos de relacionados com eles, teria dado voltas desnecessárias. Obrigada pela paciência em responder minha perguntas e duvidas. Obrigada pelo seu apoio sem você teria estado perdida.

Aldo, obrigada por todo apoio tanto com PCRarray como escrita do artigo. Seu aporte e discussão de protocolos, ideias e resultados durante todo o doutorado foi uma inspiração.

Agradeço imensamente a Izabel, por abrigar-me novamente em sua casa (no mestrado foi o mesmo) com sua família, ajudando-me enfocar na escrita da tese e fazendo correções 
incríveis do meu português ruim. Por o seu apoio e sua amizade. Não tenho como agradecer, você é um verdadeiro sol depois de anos de tempestades. Obrigada! Obrigada! Obrigada!

Daniel, meu parceiro de jornada, obrigada pelo seu apoio em todas as etapas, nas aventuras e desventuras trabalhando com camundongos, em todos os planos maquiavélicos tratando de conquistar o mundo. Também quero agradecer a você e ao Thiago pela caixa rosa de chocolate. Vocês não sabe que tão importante ela é para mim e minha sanidade mental. Obrigada.

Ana Camila, por sua orientação com os camundongos, amizade e infinita paciência. Obrigada por todo seu apoio no sanduiche, por me abrigar e me ajudar na minha enfermidade. Você foi como uma irmã para mim. Sempre vou torcer para seu futuro seja brilhante.

Agora as coisas se complicam. Tenho muitos agradecimentos, todos importantes e sem ordem específica. Quero agradecer a Lorena, pela amizade, apoio e correções de português, e a Fernanda, Marco, Patty e o pessoal do Lab3 (MOA) pelo ambiente agradável de trabalho e amizade. Agradeço, também, a Lídia por prover-me de livros absorventes, empolgantes, nos meus momentos de desespero. Obrigada pela conversas e sua visita! Finalmente, àqueles que esqueci de citar, muito obrigada!

Por ultimo, mas não menos importante, agradeço à FAP-DF, pelo financiamento deste projeto por meio do Projeto Pronex, ao CNPq, pela bolsa de doutorado, e à CAPES, pela bolsa de doutorado sanduíche no exterior, ao Programa de Pós-graduação em Biologia Molecular.

Gente, obrigada por fazer meu caminho interessante!

"Caminante no hay camino, se hace camino al andar..." 


\section{RESUMO}

A paracoccidioidomicose (PCM) é uma doença endêmica, considerada a micose sistêmica mais prevalente no Brasil. A resposta ao agente etiológico, o fungo Paracoccidioides spp. é multifatorial e complexa, sendo que a natureza da resposta imune inicial, ou inata, resultará em um padrão de suscetibilidade ou resistência à PCM. Este estudo teve como principal foco a análise dos padrões moleculares de suscetibilidade ao $P$. brasiliensis, comparando as diferenças na resposta de células importantes na primeira linha de defesa ao fungo, por meio da análise da expressão gênica, em duas linhagens de camundongo: uma suscetível (B10.A) e outra resistente (A/J). Para isto, células dendríticas (BMDC) e macrófagos polarizados (MIlike, GM-BMM, e M2-like, M-BMM), derivados da medula óssea dessas duas linhagens murinas, foram co-cultivados, na ausência ou na presença de leveduras de $P$. brasiliensis. Após 6 horas, de co-cultivo, o RNA das BMDCs foi extraído e empregado em análises transcritômicas em larga escala (RNA-seq). As análises preliminares validam a qualidade das sequências obtidas e asseguram seu uso nas etapas subsequentes das análises dos dados gerados pelo experimento de RNA-seq. Dentre os genes descritos como diferencialmente expressos entre o grupo controle (não infectado) e o grupo experimental, oito tiveram sua expressão validada por qRT-PCR. Os genes diferencialmente expressos em ambas as linhagens foram agrupados por ontologia gênica e vias de KEGG para fornecer um panorama geral da reprogramação do transcritoma em resposta à infecção por P. brasiliensis. Em resumo, as BMDCs da linhagem A/J montam uma resposta controlada com poucos genes diferencialmente expressos em relação à condição controle. Já, as BMDCs da linhagem B10.A apresentam uma resposta intensa, com uma maior variação de expressão diferencial de genes. Neste trabalho, também avaliamos o impacto da polarização de macrófagos no modelo murino de PCM. Em geral, independente da linhagem de camundongos, os macrófagos com polarização similar a M2 (M-BMM), mostraram-se mais bem equipados para combater o fungo, apresentando o aumento nos níveis de transcritos de quimiocinas e citocinas. Ainda sobre o padrão desta resposta de macrófagos do tipo M2, também foi observado que comparado a B10.A, os M2-like de A/J desenvolveram uma resposta mais efetiva quanto ao controle da infecção, tendo sido também observado o aumento nos níveis de transcritos associados às vias de transdução de sinal dos TLRs, Dectina-1 e complemento, entre ouros. Por outro lado, os macrófagos com a diferenciação similar a M1 (GM-BMM) de ambas as linhagens de camundongo aumentaram os níveis dos transcritos de IL-2, IL-6, IL-10, IL-12 e TNF- $\alpha$ quando comparados aos M-BMMs (tipo M2) infectados. GM-BMMs de B10.A mostrou uma diminuição nos níveis de alguns transcritos associados às vias de sinalização a partir de TLRs, Dectina-1 e complemento, entre outros PRRs anti-fúngicos, quando comparados aos GM-BMMs da linhagem A/J.

Palavras-chave: Paracoccidioides brasiliensis, Células Dendríticas, Macrófagos, Resistência/Susceptibilidade, RNA-seq 


\begin{abstract}
Paracoccidioidomycosis (PCM), a rural and suburban endemic disease, is considered the most prevalent systemic mycosis in Brazil. The response to its etiological agent (Paracoccidioides spp.) is multifactorial and complex. However, the manner in which the initial response is developed will determine if the patient presents a resistance or susceptibility to this infection. The focus of this study was to analyze the molecular patterns of susceptibility to P. brasiliensis infection, by comparing the differences in gene expression of cells of a susceptible (B10.A) and a resistant (A/J) mice strain, important in the first line of defense, in response to this fungus. To this end, dendritic cells (BMDC) and polarized macrophages (M1-like, GM-BMM, and M2-like, M-BMM) derived from the bone marrow of both murine strains were co-cultured with P. brasiliensis. After 6 hours co-culture, the RNA extracted from dendritic cells were sequenced by RNA-seq. Preliminary analysis of the RNAseq data validated the quality of the sequences obtained and therefore ensured their use in subsequent steps of analysis. Of these, the expression of eight genes, up-regulated and/or not modulated, were validated by qRT-PCR. The genes differentially expressed in both strains were grouped then by gene ontology and KEGG pathways to provide an overview of the transcriptome reprogramming to $P$. brasiliensis infection. In summary, the BMDCs of the A/J strain mounts a controlled response with few differentially expressed genes relative to the control condition. While, the BMDCs of B10.A strain presents a more intense response with a wider range of differential gene expression. In this work, we also evaluated the impact of macrophage polarization in the murine model of PCM. In general, regardless of mouse strain, macrophages with M2-type polarization (M-BMM), proved to be better equipped to fight the fungus, with increase transcripts accumulation of chemokines and cytokines. Even within this polarazition, in comparison with B10.A M-BMMs, A/J M-BMMs developed a more effective control of infection, being also observated an increase in the transcripts levels associated with the signal transduction of TLRs, Dectin-1, complement, and others. Moreover, the macrophages with type M1 differentiation (GM-BMM) infected with P. brasiliensis of both mouse strains increased transcript levels of IL-2, IL-6, IL-10, IL-12 and TNF- $\alpha$ when compared to infected M-BMMs (M2 type). B10.A GM-BMM showed a decrease in the levels of some transcripts associated with TLR, Dectin-1 and complement signaling pathways, and other associated antifungal PRRs when compared to A/J GM-BMM.
\end{abstract}

Keywords: Paracoccidioides brasiliensis, Dendritic cells, Macrophages, Resistance/Susceptibility, RNA-seq 
1 CONTEXTUALIZAÇÃO DO PROJETO DE DOUTORADO ……............................. 1

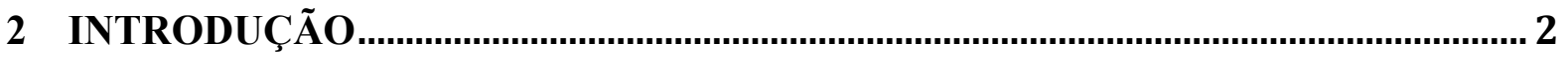

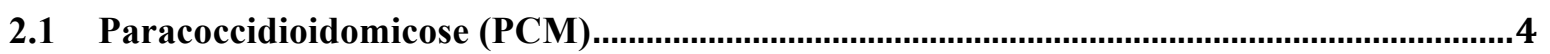

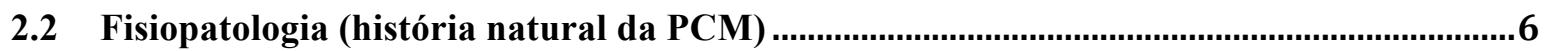

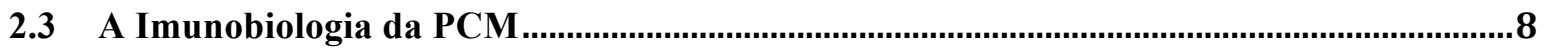

2.3.1 Componentes do Sistema Imune na PCM.........................................................................12

2.3.2 Perfil de Resistência/Susceptibilidade Associados à PCM ..................................................21

2.4 Análise transcritômica em larga escala em estudos de interação ...................................... 25

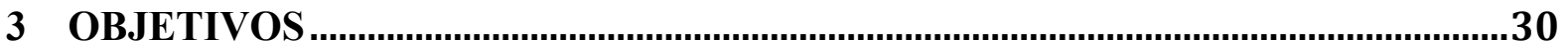

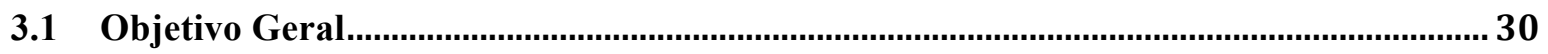

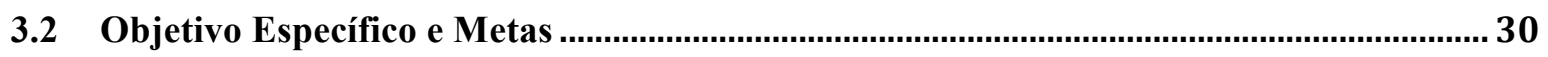

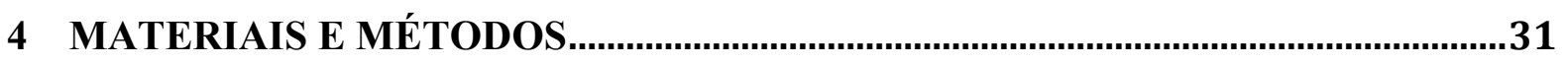

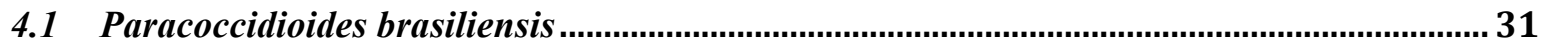

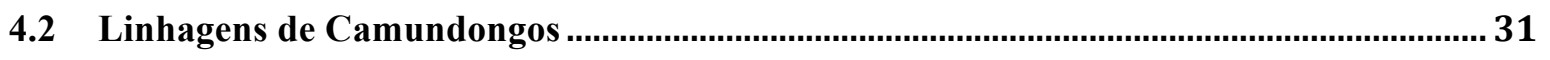

4.2.1 Eutanásia dos camundongos e obtenção de soro …………...................................................

4.2.2 Isolamento de células da medula óssea de camundongos ....................................................33

4.3 Desenho Experimental da Infecção Ex-Vivo de Macrófagos (tipo M1 ou M2) e Células Dendríticas Derivados da Medula Óssea de Camundongos A/J e B10.A com P. brasiliensis.. 36

4.4 Determinação da carga fúngica por contagem das unidades formadoras de colônia (UFC).

4.5 Análise da internalização de leveduras de $\boldsymbol{P}$. brasiliensis por células derivados da medula

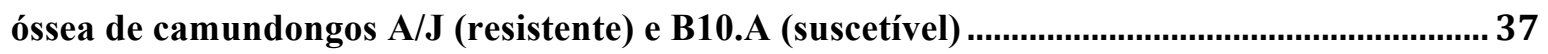

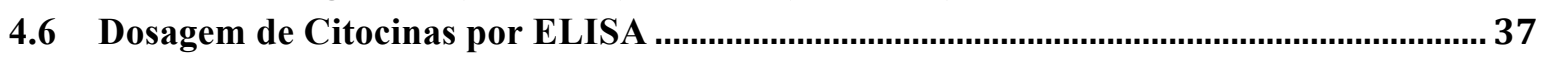

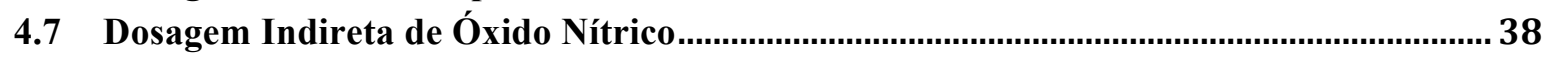

4.8 Análise Estatística nos estudos de produção de citocina/quimiocina e óxido nítrico...... 38

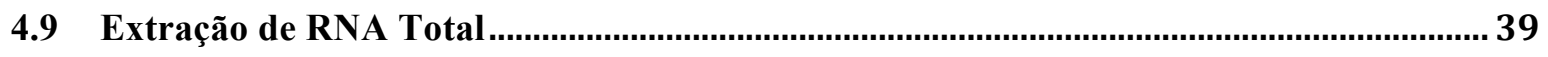

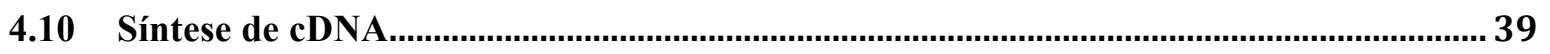

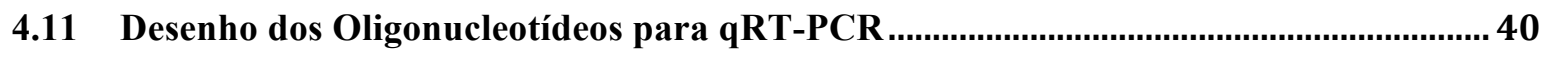

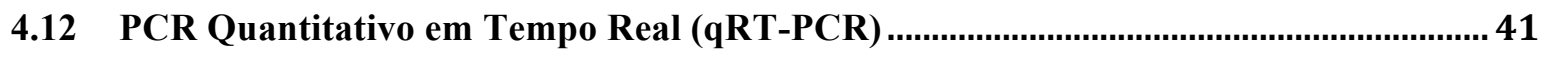

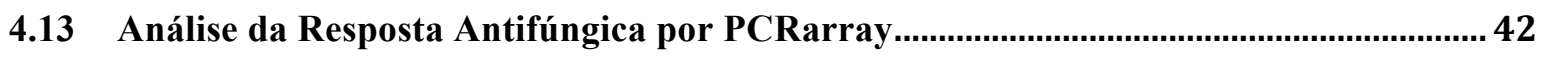

4.14 Análise Estatística da Expressão dos Genes (qRT-PCR e PCRarray) ............................ 43

4.15 Preparo das Amostras para RNA-Seq, Sequenciamento e Análise dos Dados.............. 43

5 RESULTADOS E DISCUSSÃO..........................................................................47

5.1 Parte I: Análises de Comparativos de BMDCs de Cultura Primária de Camundongos

Resistentes e Suscetíveis à Infecção por P. brasiliensis ................................................................ 48

5.1.1 Análise transcritômica em larga escala (RNA-Seq) da expressão gênica de mRNA de

BMDCs provenientes de hospedeiros murinos resistentes e susceptiveis à $P C M$.............................48

5.1.2 Alguns Dados de Expressão Diferencial dos resultados do RNA-seq ...................................54 


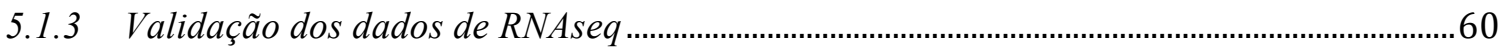

5.2 Parte II: Caracterização de GM-BMM e M-BMM das Linhagens de Camundongos A/J

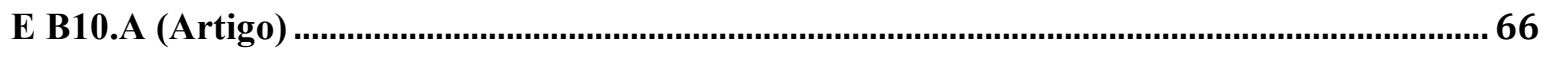

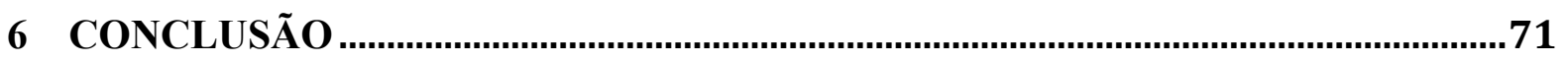

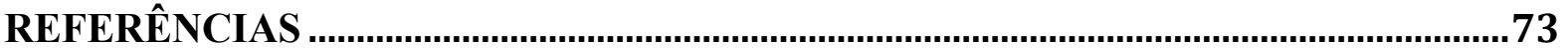

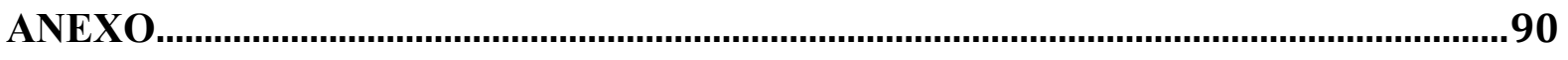

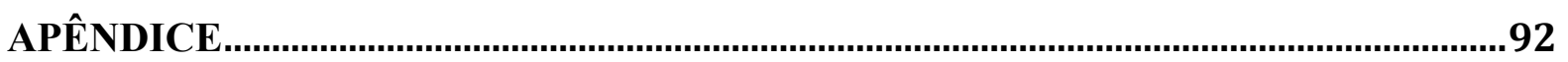




\section{FIGURAS}

Figura 2.1. Resumo dos rumos da interação parasito-hospedeiro na PCM humana (adaptado de Benand, 2008)..

Figura 2.2. PRR e suas vias de sinalização que conduzem à diferenciação de células $T$ auxiliares na defesa antifúngica. Verma et al. (2015)...

1Figura 2.3. Modulação das subpopulações de células T CD4 + por células dendríticas em infecções fúngicas (revisado e adaptado de Romani 2011).

Figura 2.4. Resumo da regulação de citocinas associadas às três principais formas de PCM, baseadas nas respostas imune à glicoproteína 43kda (gp43), componente antigênico imunodominante da forma leveduriforme de P. brasiliensis.

Figura 2.5. $O$ M1/M2 paradigma, a origem e a base molecular (adaptado e revisado em Martinez e Gordon 2014).

Figura 2.6. Principais características do modelo isogênico murino de resistência e suscetibilidade à infecção pelo fungo Paracoccidioides brasiliensis (Calich et al. 2008).

Figura 2.7. Hipótese sobre os mecanismos imunológicos inatos e adquiridos que resultam na resistência/suscetibilidade à infecção por P. brasiliensis. .

Figura 4.1. Pipeline de análise empregado para análise dos dados de RNA-seq. 45

Figura 5.1. Validação da qualidade das amostras de RNA a serem enviadas para o experimento de RNA-seq.

Figura 5.2. Representação da inter-relação entre os perfis de expressão gênica das amostras.

Figura 5.3. Representação gráfica dos genes diferencialmente expressos no modelo de infecção de BMDCs com P. brasiliensis para as linhagens de camundongo A/J e B10.A, segundo os parâmetros de FDR $<0,05$ e MagnFC $>1,4$.. 52

Figura 5.4. Representação quantitativa e visual do comportamento dos genes diferencialmente modulados em BMDCs de camundongos A/J e B10.A após infecção com P. brasiliensis.

Figura 5.5. Comparação dos padrões de expressão dos resultados obtidos pelas metodologias de qRT-PCR e RNA-seq para os níveis de transcritos de genes relacionados à resposta imune de BMDCs das linhagens de camundongos resistente (A/J) e susceptíveis (B10.A) após infecção por P. brasiliensis.

Figura 5.6. Acúmulo de transcritos de genes relacionados à resposta imune em BMDCs das linhagens A/J e B10.A após infecção por P. brasiliensis.

Figura 5.7. Quantificação da produção das citocinas TNF- $\alpha$ (a), IL-6 (b), IL-10 (c), e da quimiocina MCP-1 (d) por BMDCs de camundongos das linhagens resistente (A/J) e suscetível (B10.A) após 6h de infecção por P. brasiliensis.

Figura 5.8. Perfis de Expressão genica baseados em Mouse Antifungal Response RTC Profiler ${ }^{\text {TM }}$ PCR Array. 
Figura 5.9. Representação esquemática dos principais resultados da expressão gênica e a produção de citocinas por GM-e M-BMMs das linhagens murinas A J e B10.A em resposta a infecção in vitro com $\mathrm{Pb18.}$ 


\section{TABELAS}

Tabela 4.1. Dados gerais dos oligonucleotídeos sintetizados. 40

Tabela 4.2. Dados gerais dos oligonucleotídeos do primerbank ................................................. 40

Tabela 4.3. Dados gerais dos oligonucleotídeos sintetizados.................................................... 41

Tabela 4.4. Dados gerais do controle interno........................................................................... 41

Tabela 5.1. Descrição dos principais dados do sequenciamento e "status" das sequências geradas.

Tabela 5.2. Categorização dos principais genes induzidos da biblioteca de BMDC da linhagem de camundongo A/J infectado com Pb18. Conforme seu GO (gene ontology) e distribuídos segundo a função no hospedeiro (categoria: GOterm BP FAT, $p<0,05$ ). Em itálico as vias em comum com B10.A (Tabela 5.3). A coluna \% representa a porcentagem na categoria do total dos genes induzidos. A ultima coluna é o p-valor corrigido para múltiplas hipóteses utilizando o método Benjamini-Hochberg.

Tabela 5.3. Categorização dos principais genes induzidos da biblioteca de BMDC da linhagem de camundongo B10.A infectado com Pb18. Conforme seu GO (gene ontology) e distribuídos segundo a função no hospedeiro (categoria: goterm BP FAT, $p<0,05)$. Em itálico as vias em comum com A/J (Tabela 5.2). A coluna $\%$ representa a porcentagem na categoria do total dos genes induzidos. $A$ ultima coluna é o p-valor corrigido para múltiplas hipóteses utilizando o método Benjamini-Hochberg.

Tabela 5.4. Vias de KEGG super-representadas para genes induzidos em BMDC da linhagem de camundongo A/J infectado com Pb18 $(p<0,05)$. Em itálico as vias em comum com B10.A (Tabela 5.5). A coluna \% representa a porcentagem na categoria do total dos genes induzidos. A ultima coluna é o p-valor corrigido para múltiplas hipóteses utilizando o método Benjamini-Hochberg.

Tabela 5.5. Vias de KEGG enriquecidas para genes induzidos em BMDC da linhagem de camundongo B10.A infectado com Pb18 $(p<0,05)$. Em itálico as vias em comum com A/J (Tabela 5.4). A coluna \% representa a porcentagem na categoria do total dos genes induzidos. A ultima coluna é o p-valor corrigido para múltiplas hipóteses utilizando o método Benjamini-Hochberg.

Tabela 5.6. Vias de KEGG enriquecidas para genes reprimidos em BMDC da linhagem de camundongo B10.A infectado com Pb18 ( $p<0,05)$. A coluna \% representa a porcentagem na categoria do total dos genes induzidos. A ultima coluna é o pvalor corrigido para múltiplas hipóteses utilizando o método BenjaminiHochberg. 


\section{LISTA DE ABREVIATURAS E GLOSSÁRIO}

$\mathbf{P b}$ - Paracoccidioides brasiliensis

DC - célula dendríticas

PCM - paracoccidioidomicose

GM-CSF - fator estimulador de colônia de granulócitos-macrófagos

M-CSF - fator estimulante de colônias de macrófagos

BMDC - Bone marrow-derived dendritic cell (Célula Dendrítica derivada de medula óssea)

BMM - Bone marrow-derived macrophage (Macrófago derivado de medula óssea)

GM-BMM -Macrófago derivado de medula óssea diferenciado com GM-CSF

M-BMM - Macrófago derivado de medula óssea diferenciado com M-CSF

CLR - C-type Lectin receptor

TLR - Toll-like receptor

NLR - NOD-like receptor

RLR - RIG-I-like receptor

ELISA - Enzyme-linked immunosorbent assay (Ensaio de imunoabsorção enzimática)

Fold Change - Expressão relativa do gene alvo em relação ao controle do experimento

IL - Inteleukin (Interleucina)

INF - Interferon

TGF - Transforming growth factor (Fator de crescimento transformante)

TNF - Tumor necrosis fator (fator de necrose tumoral)

MCP-1 - Monocyte Chemoattractant Protein 1 (Proteína quimiotática de monócitos 1 também chamado CCL2)

MOI - Multiplicity of infection - Proporção de células de patógeno x hospedeiro

mRNA - RNA mensageiro

rRNA - RNA Ribossômico

tRNA -RNA transferência

miRNA - micro RNA

cDNA - DNA copia

NGS - Next-generation sequencing (Sequenciamento de nova geração), também chamado high throughput sequencing.

SAGE - análise em série de expressão gênica

RNA-Seq - sequenciamento de mRNA 
PBS -Phosphate buffered saline (Solução salina tamponada com fostato). Tampão de pH próximoao fisiológico comumente usado em procedimentos com células de mamíferos.

PRR - Pattern Recognition Receptor (Receptor de Reconhecimento de Padrão)

PAMP - Pathogen Associated Molecular Pattern (Padrão Molecular Associado a Patógeno)

qRT-PCR - Quantitative Real-Time Polymerase Chain Reaction

RPM - Rotações por minuto

SFB - Soro fetal Bovino 


\section{CONTEXTUALIZAÇÃO DO PROJETO DE DOUTORADO}

Dentre as respostas das células do sistema imunológico do hospedeiro aos diversos estímulos externos, aquelas desencadeadas pela interação com os microrganismos são de grande interesse. Nesta interação, são observadas mudanças no padrão de expressão dos genes tanto do hospedeiro quanto do patógeno, que são importantes para o curso da infecção.

Uma vez que a incidência e a prevalência de doenças fúngicas sistêmicas representam um problema de saúde mundial, as pesquisas nesta área são de relevância médica. Este projeto de doutorado insere-se em um projeto maior, "Caracterização das bases moleculares da suscetibilidade imunológica à infecção fúngica sistêmica e seleção de peptídeos antimicrobianos com ação imunoregulatória" (PRONEX/FAPDF/CNPq -edital 03/2009; Processo 193.000.571/2009), que tem como objetivo principal caracterizar a resposta imune do hospedeiro contra os fungos Candida albicans, Criptococcus neoformans e Paracoccidioides brasiliensis, para o melhor entendimento das bases moleculares de resistência/suscetibilidade dos hospedeiros às infecções fúngicas, assim como identificar potenciais alvos terapêuticos e novos fármacos ativos no tratamento de micoses sistêmicas.

O nosso núcleo "Imunologia Molecular de Micoses Sistêmicas"- responsável pelo projeto Pronex/FAPDF/CNPq - Edital 03/2009 (Processo 193.000.571/2009)- reúne pesquisadores da Universidade de Brasília (UnB), do Hospital Universitário de Brasília (HUB) e da Universidade de São Paulo (USP). Há, ainda, vínculos e colaborações com o grupo de pesquisa liderado pelo Dr. Arturo Casadevall, do Albert Einstein College, NY/USA. A análise do padrão de expressão gênica diferencial do hospedeiro em resposta à infecção fúngica foi realizada por meio do sequenciamento de mRNA (RNA-seq) em larga escala. 


\section{INTRODUÇÃO}

A elevação da incidência de doenças fúngicas tem sido atribuída não somente ao aumento no número de pacientes imunocomprometidos (Chakrabarti A. 2005, Menzin et al. 2009, Prado et al. 2009, Rivera, 2014, Dignani et al. 2014), mas também à registros em indivíduos imunocompetentes (Ali et al. 2003, Bigliazzi et al. 2004, Thorpe et al. 2004, Chen et al. 2008, Saini et al. 2010).

Dentre as doenças fúngicas, as denominadas invasivas são a maior causa de morbidade e mortalidade entre os pacientes imunocomprometidos, e impactam nos custos dos serviços de saúde, principalmente devido a complexidade do diagnóstico, da prevenção e do tratamento. As taxas de mortalidade nestes agravos são superiores a 30\% mesmo sob a introdução de novas classes de antifúngicos (azóis e equinocandinas) na prática clínica (Brown e Netea 2012, Dignani et al. 2014). Por outro lado, a dificuldade no diagnóstico implica em um tratamento empírico, com uso de diversas ferramentas, incluindo dados epidemiológicos, métodos não padronizados e imagens (Brown e Netea 2012, Dignani et al. 2014). Adicionalmente, grande parte da informação epidemiológica pode não estar precisa dado que se estima uma chance de $50 \%$ deste diagnóstico ocorrer posteriormente a morte (Dignani et al. 2014, Coutinho et al. 2015). No Brasil, este cenário é similar. Entre 1996 e 2006, cerca de 3500 mortes ocorreram em consequência das doenças fúngicas, entre elas paracoccidioidomicose (PCM), criptococose, histoplasmoses, candiadíase, aspergilose, coccidioidomicose e zigomicose (Prado et al. 2009, Coutinho et al. 2015). Esse número pode ser ainda maior dado que a notificação de pacientes diagnosticados com micoses sistêmicas não é mandatória, porém os registros de autopsias podem ser uma ferramenta útil dado que complementa o diagnóstico desse tipo de doença (Hotez et al. 2008, Dignani 2014).

Por outro lado, os tratamentos tradicionais requerem longos períodos de tempo, e podem acarretar efeitos colaterais severos, além da possível seleção de microrganismos resistentes (Carrillo-Munoz et al. 2006, Kauffman 2006, Perlin 2015, Sanguinetti et al. 2015). Ainda, o desenvolvimento de outros possíveis tratamentos e vacinas ainda está em fase de pesquisa clínica. (Santos e Levitz 2014, Davis et al 2015).

Neste sentido, tem-se a urgência das pesquisas na área de doenças fúngicas. Atualmente há um aumento de interesse de áreas interdisciplinares, e suas publicações apontam a necessidade de conscientização e suporte para projetos de pesquisa com intuito de elaborar e testar novos fármacos e tratamentos alternativos para as infecções micóticas 
(Brown et al. 2012). Entre os estudos na área, aqueles relativos às respostas protetoras do sistema imunológico do hospedeiro na interação com os microrganismos são os de maior destaque, já que o conhecimento adquirido influenciará diretamente o tratamento e, portanto, no prognostico do paciente (Brown et al. 2012, Brown e Netea 2012).

Sabe-se que a defesa imunológica do hospedeiro mamífero contra as micoses sistêmicas é complexa e multifatorial, e depende de mecanismos inatos e adaptativos (Janeway et al. 2001). A resposta inata está relacionada no controle inicial da infecção e influencia o desenvolvimento da imunidade adaptativa, celular ou humoral, quando ocorre a persistência do patógeno (Janeway et al. 2001).

Sendo assim, o entendimento das bases moleculares da resposta do hospedeiro à infecção por patógenos e sua regulação é essencial para o conhecimento de mecanismos e vias pelas quais patógenos evadem-se do sistema imunitário. A interação patógenohospedeiro pode resultar em diversas alterações na célula hospedeira, dentre elas a ativação de vias de sinalização celular com a reprogramação do transcritoma. Por isso, se torna cada vez mais importante, a compreensão do complexo como um todo: mudanças no padrão de expressão dos genes tanto do hospedeiro quanto do patógeno; estado hormonal, nutricional, psicológico e estado da microbiota do hospedeiro; tamanho do inóculo e isolado do patógeno; e, principalmente, como a interação hospedeiro-patógeno é regulada.

Diversas metodologias, tais como microarranjos, análise em série de expressão gênica (SAGE) e, mais recentemente, o sequenciamento de mRNA (RNA-Seq) foram desenvolvidas e aperfeiçoadas para a quantificação de transcritos em larga escala. Essas metodologias permitem a análise simultânea de milhares de genes, e fornecem uma compreensão global da evolução temporal do padrão de expressão gênica do hospedeiro em resposta à interação com o patógeno. Nesse contexto, o presente estudo tem como objetivo caracterizar o perfil transcricional do hospedeiro (modelo experimental murino) em resposta imune à infecção pelo fungo Paracoccidioides brasiliensis. 


\subsection{Paracoccidioidomicose (PCM)}

A paracoccidioidomicose (PCM) -doença endêmica rural e suburbana cujo agente etiológico é fungo dimórfico Paracoccidioides brasiliensis- é considerada a micose sistêmica mais prevalente no Brasil e encontra-se presente em vários países da América Latina (Coutinho et al. 2002, Prado et al. 2009, Martinez 2010, Colombo et al. 2011, Coutinho et al. 2015). No entanto, um novo estudo filogenético revelou que o agrupamento de isolados conhecidos como Pb01-like é uma nova espécie dentro do genus Paracoccidioides agora denominado P. lutzii que também é um agente casual de PCM (Texeira et al. 2009). Esta micose é mais prevalente em homens que mulheres devido a fatores biológicos, como o efeito protetor do hormônio estrógeno (Shankar et al. 2011, Bernin et al. 2014), e comportamentais, como as condições de trabalho, p.ex., trabalhadores rural (Brummer et al. 1993, Bethlem et al. 1999).

Devido a suas numerosas manifestações clínicas, seu diagnóstico diferencial deve ser muito cauteloso (ver tabela 1). É comum ocorrer confusão no diagnóstico da PCM principalmente com a tuberculose pulmonar, que apresenta alterações radiográficas e clínicas similares. O diagnóstico diferencial das duas patologias é definido pela presença ou do fungo, no caso do PCM, ou do bacilo de Koch, no caso de turberculose (Wanke e Aidê 2009, Coutinho et al. 2015). Outro agravante é que entre 5,5 e 19\% dos pacientes com PCM podem ser co-infectados com Mycobacterium tuberculosis, tornando-se mais difícil o diagnóstico de ambas (Wanke e Aidê 2009, Coutinho et al. 2015).

Tabela 1. Principais doenças que requerem um diagnóstico diferencia em relação com PCM (Wanke e Aidê 2009).

- Tuberculose pulmonar e micobacterioses - Coccidioidomicose atípicas

- Sarcoidose

- Histoplasmose

- Pneumonite intersticial difusa idiopática

- Silicose crônica

- Cromoblastomicose

- Leishmaniose cutânea e visceral

- Hanseníase

- Neoplasias cutâneas e da laringe

A não obrigatoriedade de notificação (Brasil, 2014) e a incerteza na nomenclatura da PCM e de outras micoses sistêmicas no Brasil, evidenciada por registros utilizando sua antiga nomenclatura "Blastomicose Sul-americana" (Smith et al. 2010), pode refletir nos dados referentes ao impacto dessa micose na saúde pública, o qual não tem sido verdadeiramente quantificado. Com isso, a PCM foi incluída na lista de enfermidades negligenciadas (Hotez et 
al. 2008). No entanto, a infecção assintomática por P. brasiliensis tem sido comprovada em quase todos os estados brasileiros (Wanke et al. 1994).

Alguns estudos estimam que cerca de 10 milhões de pessoas possam estar infectadas e que aproximadamente $2 \%$ destas desenvolvem a doença (Restrepo et al. 2001), já outros sugerem que número de indivíduos infectados é cerca de $10 \%$ da população brasileira (Wanke et al. 1994). Ou seja, se esta estimativa estiver correta, sua prevalência poderia ser equiparável com a doença do Chagas na América Latina, e supera, assim, outras doenças negligenciadas como a leishmaniose e a esquitossomose (Hotz et al. 2008, Martinez 2010).

A relevância do impacto da PCM na saúde é ainda notificada em trabalho que relatam que esta micose foi responsável pela maioria do número de mortes atribuídas às sete principais doenças fúngicas sistêmicas entre os anos de 1996 e 2006, aproximadamente $51.2 \%$ dos casos (Coutinho et al. 2015). Sua taxa de mortalidade por um milhão de habitantes no Brasil foi de 1,45 entre os anos de 1980-1995 e 0,9-1,0 nos anos 1996 a 2006 (Coutinho et al. 2002, Prado et al. 2009, Coutinho et al. 2015). Igualmente, entre 1980 e 1995, a PCM foi a oitava causa de morte mais predominante dentre as doenças crônicas em 1166 municípios brasileiros (Coutinho et al. 2002). Porém, quando a AIDS é considerada a causa subjacente de morte e a micose sistêmica como condição associada, a criptococose $(50.9 \%)$ aparece no topo da lista, tendo-se em seguida, a candidíase (30.2\%), a histoplasmose (10.1\%), entre outros (Prado et al. 2009). Entretanto, presume-se que a incidência dos indivíduos que desenvolvem a PCM poderá elevar-se com o aumento do desmatamento e do número de indivíduos imunodeficientes (Courtinho, 2015).

Embora existam alguns agentes antifúngicos eficazes disponíveis para a cura clínica da PCM (por exemplo, sulfudamidas, azóis, anfotericina B), ainda há registros de mortalidade pela doença. Isto ocorre porque muitas vezes o tratamento inicia-se quando o fungo já se disseminou para outros órgãos, o que exige que o tratamento seja prolongado, comumente mais de um ano, para evitar recidivas (Carrillo-Munoz et al. 2006, Martinez 2010, Coutinho et al. 2015). Além disso, os efeitos colaterais dos mesmos medicamentos, em conjunto com o aumento da resistência aos antifúngicos por isolados de P. brasiliensis, dificulta a adesão ao tratamento e eficácia do mesmo (Hahn et al. 2003, Carrillo-Munoz et al. 2006, Kauffman 2006, Cowen 2008, Coutinho et al. 2015).

Por outro lado, em pelo menos $20 \%$ dos pacientes que apresentaram recidivas, são registradas complicações com sequelas tanto anatômicas como funcionais, tal qual a fibrose pulmonar e sua subsequente insuficiência respiratória, que podem ser incapacitantes (Martinez 2010, Coutinho et al. 2015). Isto pode ter impactos sócio-econômicos, dentre eles a 
aposentadoria precoce do paciente (Coutinho et al. 2015). Conforme observado em outras doenças negligenciadas, são condições agravantes da PCM: o alcoolismo, o tabagismo, desnutrição, tuberculose, neoplasias, e AIDS (Morejón et al. 2009, Martinez 2010).

Sendo assim, torna-se necessário entender o outro lado da dinâmica da interação parasita-hospedeiro, visando desenvolver novos tratamentos ou modular a resposta imune reduzindo o tempo de convalescência e dano ao paciente.

\subsection{Fisiopatologia (história natural da PCM)}

O fungo termodimórfico $P$. brasiliensis se encontra como micélio à temperatura ambiente $\left(25^{\circ} \mathrm{C}\right)$ e como levedura à $37^{\circ} \mathrm{C}$ (San-Blas et al. 1975, San-Blas et al. 1985, SanBlas et al. 1993). A sua forma leveduriforme tem sido isolada facilmente em pacientes, tatus e cães infectados (Costa et al. 1995a, Costa et al. 1995b, Ono et al. 2001, Restrepo et al. 2001, Bagali et al. 2006, Bagali et al. 2008). Este fungo também tem sido isolado, esporadicamente, de solo e materiais relacionados, tais como rações de cachorros e fezes de pinguins e morcegos (Franco et al. 2000, Tercarioli et al. 2007). Apesar de não se conhecer muito bem os aspectos ecológicos deste fungo, existem várias evidências que apontam o solo como o principal habitat saprofítico, como descrito para outras espécies termodimórficas relacionadas: Blastomyces dermatitidis (Baugardner et al. 1999), Coccidioides immitis (Kirkland et al. 1996), e Histoplasma capsulatum (Zeidberg et al. 1952).

Embora o ciclo biológico de $P$. brasiliensis não tenha sido completamente desvendado, acredita-se que a infecção ocorra pela inalação de conídios ou fragmentos de micélio da fase saprofítica do fungo, os quais atingem primeiramente o aparelho respiratório do hospedeiro (Brummer et al. 1993, Restrepo et al. 2001, Restrepo et al. 2012, Restrepo et al. 2014). No pulmão, ocorre a transição dos conídios e/ou fragmentos de hifa para a forma de levedura; no entanto nem os mecanismos envolvidos em sua disseminação nem o modo pelo qual o fungo atinge os compartimentos intravasculares de vários órgãos estão esclarecidos (Franco et al. 1987, Mendes-Giannini et al. 2008). Após a inalação, a manifestação clínica e os rumos da infecção irão variar de paciente a paciente, dependendo da resposta imunológica do hospedeiro e da virulência do fungo (Figura 2.1). Nos indivíduos resistentes, a infecção pode tornar-se latente ou ainda ser erradicada sem causar danos ao 
hospedeiro (Franco et al. 1987, Sans-Blas et al. 2002). Em áreas endêmicas, muitos casos de infecção subclínica têm sido reportados, o que indica a presença da elevada resistência natural a esta infecção (Brummer et al. 1993). Nos indivíduos susceptíveis, a doença se torna aguda ou crônica e as leveduras podem se disseminar pelo organismo (Brummer et al. 1993).

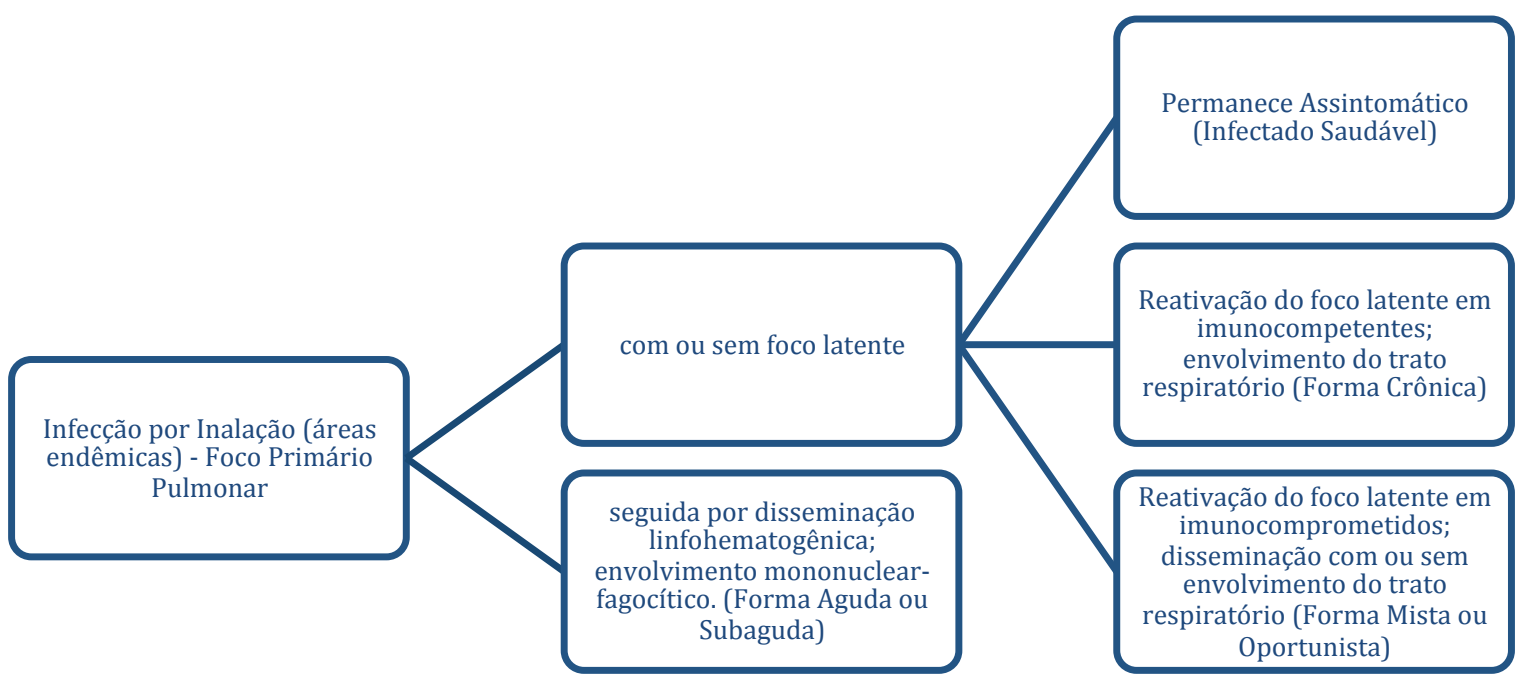

Figura 2.1. Resumo dos rumos da interação parasito-hospedeiro na PCM humana (adaptado de Benand, 2008).

Em ambos os casos supracitados, as etapas de adesão, invasão, colonização e disseminação de P. brasiliensis são consideradas cruciais no desenvolvimento das diferentes formas da PCM, dependendo de vários fatores, tais como o isolado do fungo e a condição do hospedeiro (Calich et al. 1985, Franco et al. 1987, Singer-Vermes et al. 1994, Calich et al. 1998, Kurokawa et al. 2005, Zhang et al. 2007, Mendes-Giannini et al. 2008, Sans-Blas et al. 2002, Calich et al. 2008). O Colóquio Internacional em Paracoccidioidomicose de 1986, citado pelo Consenso Brasileiro em Paracoccidioidomicose, estabeleceu a classificação das diferentes formas clínicas da PCM relacionando os dados clínicos e a história natural da doença em (Wanke e Aidê 2009):

i) paracoccidioidomicose infecção

ii) paracoccidioidomicose doença

iii) forma aguda/subaguda infantil/da adolescência

iv) forma crônica do adulto: unifocal e multifocal

v) forma residual

Portanto, é importante compreender as interações hospedeiro-fungo a fim de proporcionar o descobrimento e desenvolvimento de novas terapias antifúngicas (MendesGiannini et al., 2008). 


\subsection{A Imunobiologia da PCM}

O primeiro local de contato entre o fungo P. brasiliensis e o hospedeiro é o epitélio respiratório, onde estão os macrófagos alveolares, que provavelmente são as primeiras células do sistema imune a interagirem com o parasita, em seguida ou em conjunto com as células dendríticas, contribuem para a sinalização e ativação da resposta imune (Romani 2004, Filler et al. 2006, Calich et al. 2008, Mendes-Giannini et al. 2004, Mendes-Giannini et al. 2008). Portanto, a primeira parte do sistema imune a ser ativado nessa interação é a resposta imune inata, que não é específica a um patógeno particular e sim ao grupo que representam (vírus, bactérias, fungos, etc.) (Adany et al. 1994, Rioja et al. 2000).

O sistema consiste de um braço humoral (proteínas do complemento, lisozimas, lactoferrina, defensinas, entre outros) e um braço celular (macrófagos, leucócitos, polimorfonucleares, células "natural killer"- NK, entre outros). Se estes mecanismos inatos falharem na eliminação da ameaça, o sistema imune adaptativo é ativado pelas células epiteliais e dendríticas alveolares, e o contexto imunológico produzido na interação direcionará ao tipo de resposta imune adaptativa a ser montada (Lambrecht et al. 2001, Lambrecht et al. 2006). Esses grupos de microrganismos apresentam padrões moleculares associados a patógenos (pathogen associated molecular patterns - PAMPs) específicos e são reconhecidos pelas células do sistema imune por meio de receptores de reconhecimento padrão (pattern recognition receptors - PRRs) (Adany et al. 1994, Rioja et al. 2000), sendo o reconhecimento do patógeno pelas células do sistema imune é fundamental para um desenvolvimento de uma defesa efetiva.

Neste sentido, a presença de uma infecção fúngica é detectada e reconhecida por PRRs que, dependo de qual for ativado, induzirá múltiplos eventos ajusantes que ativarão cascatas de sinalização destinadas a eliminar o agente patogênico, incluindo a fagocitose, a geração de radicais oxidativos (explosão respiratória), e a liberação de citocinas e quimiocinas (Brown e Netea 2012), como também influencia o direcionamento do desenvolvimento da resposta imune inata (Rivera 2014). Quatro famílias de PRRs estão envolvidas no reconhecimento fúngico: os receptores Toll-like (TLR) NOD-like (NLR) RIGI-like (RLR) e lectina do tipo C-like (CLR), cada um dos quais diferem no reconhecimento do ligante, na via de transdução de sinal e a localização sub-celular, conforme resumido na figura 2.2 (Brown e Netea 2012). Destas, as duas famílias mais bem caracterizadas são a TLR e CLR (Rivera 2014). A maioria dos PRRs é expressa em células dendríticas (DC) e outras 
células mielóides, e são notáveis por iniciar a defesa imune inata (Brown e Netea 2012). Igualmente, a sinalização via PRR pode dirigir o desenvolvimento da resposta imunitária adaptativa por meio da secreção de citocinas e apresentação de antígenos, que polarizam as células T CD4 ${ }^{+}$(células T auxiliares ou Th) (Verma et al. 2014, Plato et al. 2015). No caso da infecção fúngica, a imunidade Th1 e/ou Th17 parece ser crucial para a eliminação da infecção (Verma et al. 2014, Plato et al. 2015, Wüthrich et al. 2015).

Conforme já mencionado, na figura 2.2 encontra-se resumido as principais vias de reconhecimento de PAMPs fúngicos discutido a seguir (informação a seguir foi adaptado e revisado em Verma et al. 2015):

A ligação de fungos ou de $\beta$-glucana na dectina-1 recruta $S y k$ para o dímero dos receptores fosforilados, o que leva à formação de um complexo que envolve Card9, BCL10 e MALT1 (BCM). Isso resulta na liberação de NF-אB consistindo de dímeros ou p65-p50 ou REL-p50 para o núcleo. Ativação de Syk também induz

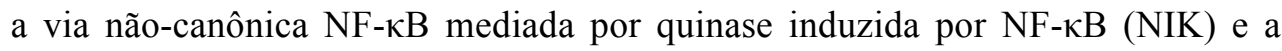
translocação nuclear de dímeros p52-RELB. Dectina-1 argumenta a produção de citocinas induzidas TLR2 e TLR4 de forma Syk-independente por meio da proteína serina/treonina quinase RAF1 por meio de proteínas Ras, o que leva à fosforilação de p65. Entre outras citoquinas, estas vias de sinalização levam à produção de IL-6, IL-23 e IL-12 que induz a polarização à células Th17 e Th1, respectivamente. O reconhecimento de C. albicans por dectina-1 também pode ativar o inflamasoma NLRP3 por meio de um mecanismo que envolve Syk, estresse oxidativo (ROS), e efluxo de potássio. Pró-IL-1 $\beta$ induzida por fungo é clivada pela caspase-1 ativa à IL-1 $\beta$ bioativa que favorecer o desenvolvimento Th17. Ativação de Dectina-2 leva à recrutamento e fosforilação de FcR-gdependente de Syk e de NF-kB e MAPKs (p38, JNK, e Erk) ativados. Card9 é necessário para a ativação de NF- $\mathrm{BB}$ e a produção de citocinas que conduzem à diferenciação de células Th17. O reconhecimento de $\alpha$-manose da Malassezia sp. por Mincle ativa a via de FcR- $\gamma$-Syk-Card9 e transloca a NF- $\kappa B$ para o núcleo que sua vez induz a ativação de citocinas pró-inflamatórias. Apesar de ainda no ter sido demonstrado de que os PAMPs fúngicos tenha capacidade de induzir algum subconjunto $\mathrm{T}$ auxiliar por esta via, o fator de cabo micobacteriana (trehalose 6 , 6'dimycolate) e o seu análogo sintético são adjuvantes potentes para a diferenciação de Th1 e Th17 induzidas por Mincle. Dectina-3 (MCL, Clec4d, ou Clecsf8) também reconhece $\alpha$-manana de C. albicans e a TDM de M. tuberculosis. Ela pode dimerizar com Dectina-2 e Mincle, e não está claro se a indução de 
células Th17 e Th1 exige o reconhecimento de PAMPs fúngicos por homo- ou heterodímeros de Dectina-2. O MR carece de um motivo de sinalização clássica na sua cauda citoplasmática curta, mas induz citocinas pró-inflamatórias que têm sido implicados na diferenciação Th1 e Th17. Apesar de células $\mathrm{T}$ de memória humanos induzidos por MR (MRin) produzirem IL-17, serão necessários mais estudos com células $\mathrm{T}$ naïve para estabelecer o papel da MRin diferenciação de células Th17. Myd88 é fundamental para a sinalização por TLR2 e TLR4. As fosfolipomananas e as mananas ligados a $\mathrm{O}$ são reconhecidos por TLR na membrana plasmática, enquanto que ácidos nucleicos de fungos são detectados por

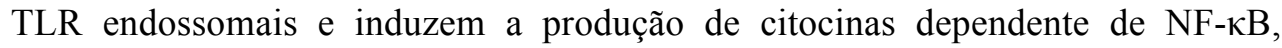
MAPK, e de IRF. A sinalização por TLR2 é provavelmente gera sinais próinflamatórios mais fracos, mas induzem forte estimulação de TGF- $\beta$ e IL-10 que por sua vez induz células $\mathrm{T}$ reguladoras. 


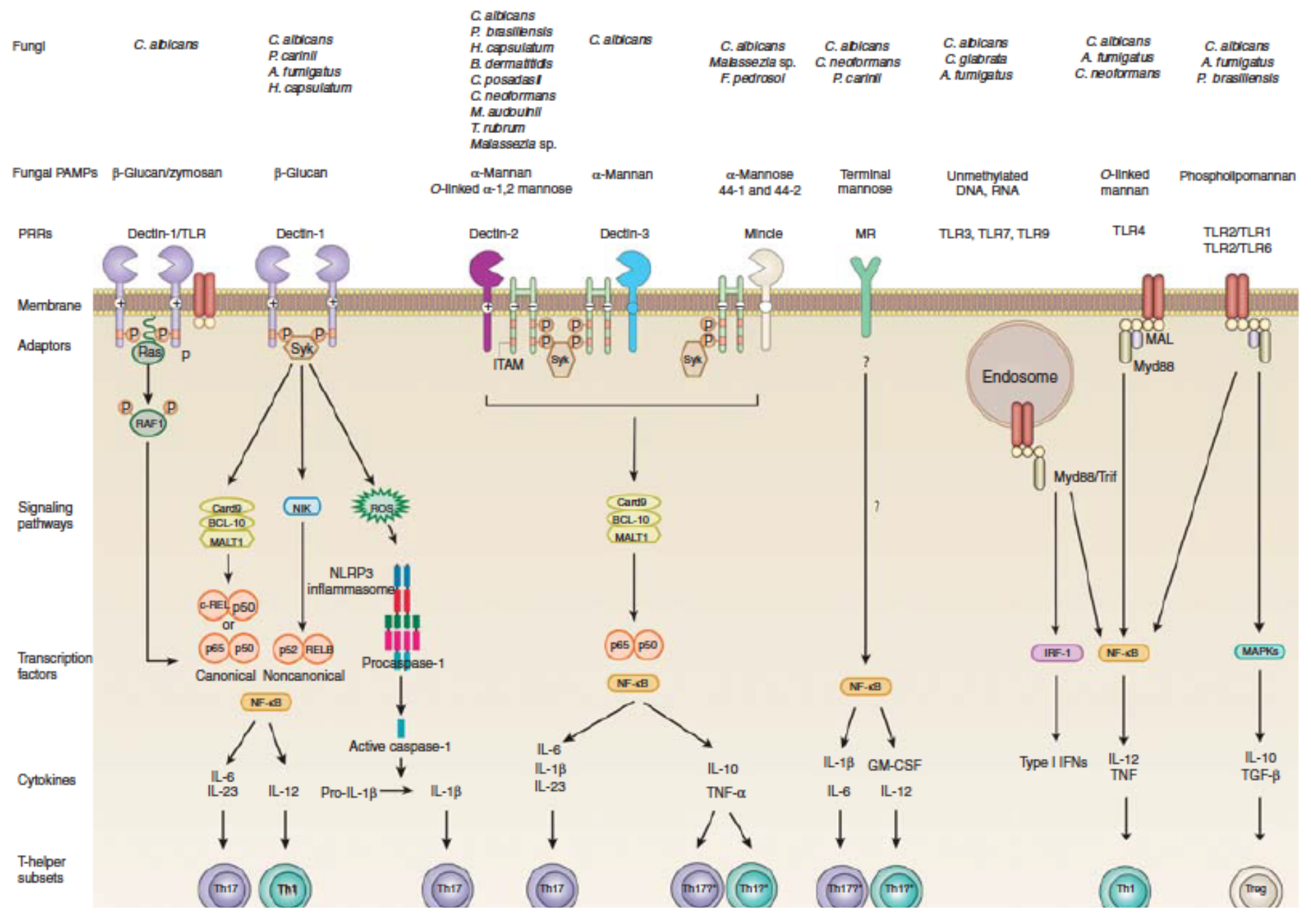




\subsubsection{Componentes do Sistema Imune na PCM}

Fundamentalmente, a ativação da imunidade inata celular é vital para o controle efetivo e proteção contra a PCM tanto em humanos como em modelos murinos (SingerVermes et al. 1994), assim como contra outros fungos (Romani et al. 2004). Nesses mesmos modelos, a resposta imune inata demonstra ter papel fundamental no controle da disseminação do fungo nas fases inicias da infecção e na determinação do destino da infecção (Calich et al. 1998, Calich 2008). Por isso, a caracterização e o entendimento das bases moleculares de resistência/suscetibilidade da resposta inata imune do hospedeiro contra $P$. brasiliensis, e como esta direciona o sistema imune como um todo, é tão importante para prever o desenvolvimento e a gravidade da doença, assim como identificar potenciais alvos terapêuticos e novos fármacos ativos no tratamento de micoses sistêmicas.

\subsubsection{CÉlulas DENDRíticas (DCs)}

As células dendríticas (DCs), entre outras células da resposta imune inata, possuem um papel crucial na defesa do organismo à infecção por patógenos aéreos (Lambrencht et al. 2001), tais como Aspergillus fumigatus, Cryptococcus neoformans, M. tuberculosis e $P$. brasiliensis. Essas células são as mais efetivas apresentadoras de antígenos, importantes na integração entre o sistema imune inato e adaptativo e na determinação da resposta imune a patógenos infectantes (Langenkamp et al. 2000, Lambrencht et al. 2001, Maldonado-Lopez et al. 2001, Wan et al. 2005, Roy et al. 2012). No tecido pulmonar e vias aéreas, as DCs se localizam dentro da parede septal alveolar e na superfície alveolar numa densa camada lidado constantemente com diferentes antígenos inalados, como a esporos e fragmentos de hifas no caso fungos, e executando a amostragens destes, sem perturbar a barreira epitelial, para o subsequente transporte aos linfonodos do mediastino e apresentação de antígenos, tanto em condições normais quanto inflamatórias (Roy et al. 2012, Verma et al. 2014, Thind et al. 2015). A via aérea tem sido alvo para vacinas intranasais contra patógenos aéreos, então, também poderia ser um local candidato para uma vacina contra fungos inalados (Roy et al. 2012). 
Existem vários tipos de DCs pulmonares, que incluem CD103+ DC e CD11b+ DC, e que tem papéis importantes na homeostase pulmonar e controle de infecção. Mas além desses subconjuntos, as DCs derivadas de monócitos (monócitos $\mathrm{Ly} 6 \mathrm{C}^{+} \mathrm{CCR} 2^{+}$à $\mathrm{DCs} \mathrm{CD} 11 \mathrm{c}-$ todas consideradas como "DC inflamatória") parecem ter um papel crucial na imunidade antifúngica, particularmente por meio da indução de células Th1 (Roy et al. 2012, Verma et al. 2014).

Cabe ressaltar que as DCs imaturas são fagocíticas, porém pobre ativadoras da resposta imune e do processamento e captação de antígenos; em contraste, as maturas servem quase exclusivamente como células apresentadoras de antígeno (Thind et al. 2015). Portanto, são as imaturas que iniciam a indução da resposta imune ao ingerir o patógeno ou suas partes no tecido infectado, tornam-se ativadas (DCs maturas) e induzem a produção de citocinas inflamatórias (Thind et al. 2015). Essas novas DCs maturas eventualmente migram aos linfonodos, onde elas interagem e ativam as células T via apresentação de antígeno (Thind et al. 2015). No processo de maturação/ativação, as DCs sofrem mudanças para que estas células ativem linfócitos patógenos-específicos e a secreção de citocinas, e com isto, fornecem dados importantes sobre o patógeno invasor que influenciarão as respostas imunes inatas e adaptativas (Thind et al. 2015).

Por isso, o papel de DCs na PCM tem sido alvo de muitas investigações nos últimos anos, uma vez que sua interação com P. brasiliensis determinará o tipo de resposta imune adaptativa a ser montada (Almeida et al. 2001, Ferreira et al. 2004, Ferreira et al. 2006, Ferreira et al. 2007). Ela faz parte da primeira linha de defesa contra o fungo e a sua migração aos linfonodos é o passo inicial chave na indução da resposta das células $\mathrm{T}$ (Figura 2.3). Vários estudos demonstram que dependendo a célula apresentadora de antígeno (macrófago, linfócitos $\mathrm{B}$, células dendríticas e/ou epitelial) estimulada haverá a influência sobre qual tipo de células $\mathrm{T}$ a ser diferenciada, e, assim se o indivíduo apresentará ou não a doença (de Almeida et al. 1998, Ferreira et al. 2003, Ferreira et al. 2004, Calich et al. 2008, Romani 2011). Assim, a resistência ao P. brasiliensis está associada a uma resposta predominantemente Th1, enquanto a suscetibilidade está relacionada a ativação de Th2 (Thind et al. 2015). 


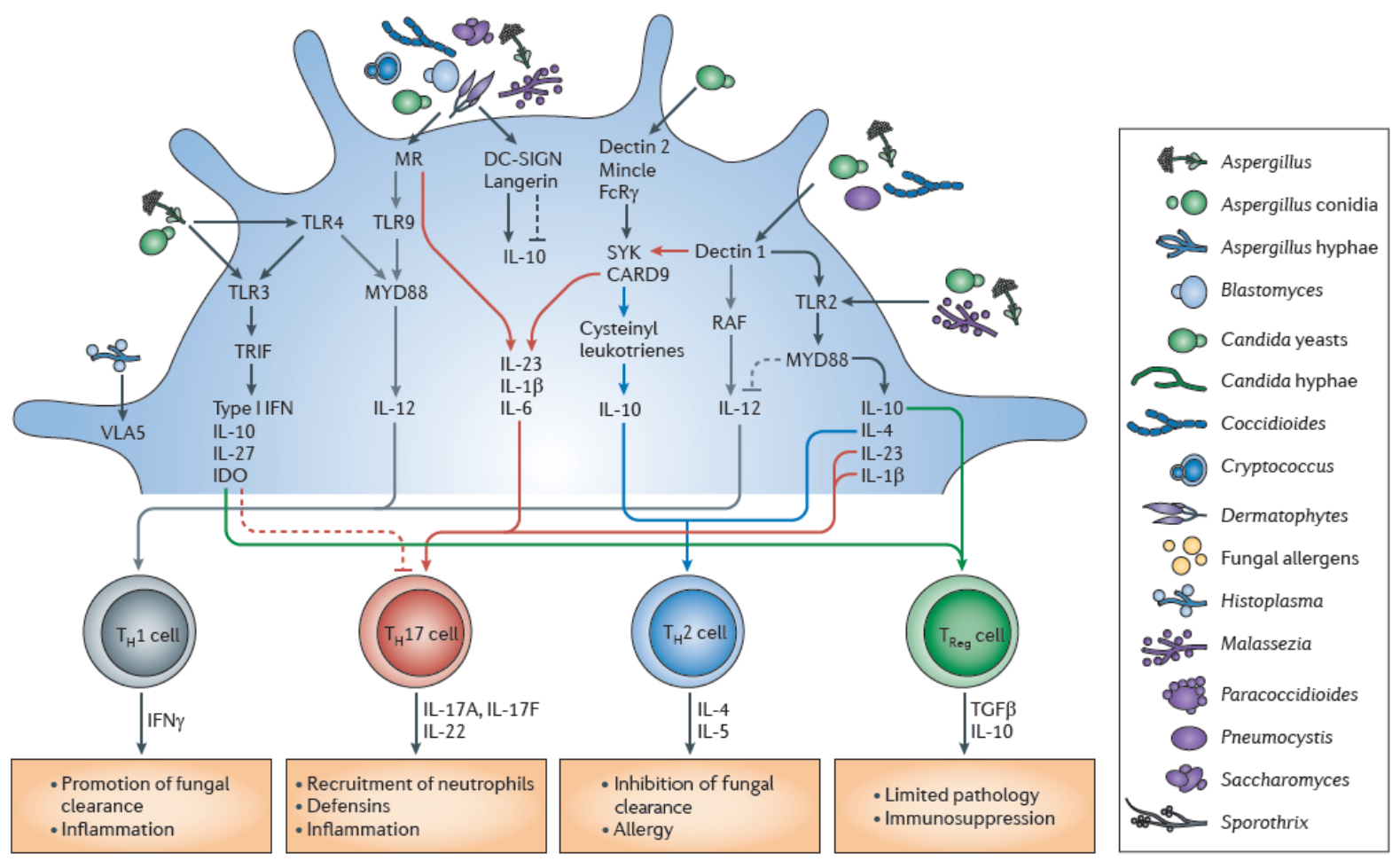

1Figura 2.3. Modulação das subpopulações de células T CD4 + por células dendríticas em infecções fúngicas (revisado e adaptado de Romani 2011).

A figura mostra a capacidade das células dendríticas para responder aos fungos com vias de sinalização intracelulares flexíveis devido a diferentes combinações de PRRs-PAMPs. Isso confere uma plasticidade inesperada ao sistema que contribui para modelar as respostas das células T, diferenciando as células em CD4 + $\mathrm{T}$ auxiliares (Th) e/ou T reguladoras (Treg), em resposta ao ataque de fungos. A figura descreve os fatores de transcrição envolvidos, as citocinas produzidas e a possíveis efetoras e funções reguladoras induzidas. Dado que por meio da produção de diferentes conjuntos de citocinas e outros mediadores, pelas distintas vias de sinalização, as células $T$ poderão ser incitadas como efetores imunes ou como reguladores mestre das respostas inflamatórias e de células efetoras inatas. Assim, este fenômeno afeta o equilíbrio Th/Treg local. Estas vias podem ser susceptíveis a fungos comensais ou oportunistas. CARD9: caspase recruitment domain-containing protein 9; CCL3: CC-chemokine ligand 3; CR3: complement receptor 3; DC-SIGN: DC-specific ICAM3grabbing non-integrin; FcR $\gamma$ : Fc receptor $\gamma$-chain; GXMR: receptor(s) for the Cryptococcus capsular component glucuronoxylomannan; IDO: indoleamine 2,3-dioxygenase; IFN: interferon; IL: interleukin; IRF3: IFNregulatory factor 3; MR: mannose receptor; MYD88: myeloid differentiation primary response protein 88; NF$\kappa \mathrm{B}$ : nuclear factor- $\kappa \mathrm{B}$; SYK: spleen tyrosine kinase; TGF $\beta$ : transforming growth fator- $\beta$; TLR: Toll-like receptor; TRIF: TIR domain-containing adaptor protein inducing IFN $\beta$ (também conhecido como TICAM1); VLA5: very late antigen 5 .

Tavares et al. (2012), com uso de "microarray", demonstraram que 299 genes foram diferencialmente expressos em DCs (Balb/c) infectadas por P. brasiliensis. Esta informação genética estava envolvida na imunidade, transdução de sinal, transcrição e apoptose. Dentre essas vias, os genes que codificam para citocinas IL-12 e TNF- $\alpha$, juntamente com quimiocinas CCL-22, CCL-27 e CXCL-10, foram induzidos na infecção por P. brasiliensis, bem como outras moléculas que participam na resposta precoce, o que sugere uma forte resposta proinflamatória em DCs para este fungo (Tavares et al. 2012). Em contraste, os genes relacionados com PRR, em particular TLRs, encontram-se reprimidos ou não modulados (Tavares et al. 2012). 
Por outro lado, Ferreira et al. (2007) demonstraram que após a infecção com $P$. brasiliensis camundongos susceptíveis (B10.A) aumentam a expressão em DC de TLR-2, que leva a um aumento na produção de IL-10 e a expressão de CD80 e CD54. Esse aumento da secreção de IL-10 nos suscetíveis provavelmente ocorre por meio da ativação de TLR-2 e de receptores dectina-1, o que levaria a uma repressão da resposta do hospedeiro microbicida. Além disso, apesar de ter o índice fagocitário maior por células suscetíveis que em camundongos resistentes (A/J) as leveduras fagocitadas eram viáveis (Ferreira et al. 2007). Ademais, dado que a laminarina, polissacarídeo que bloqueia receptores dectin-1, somente inibiu DCs nos suscetíveis e a presença da manana inibiu a fagocitose nas DCs obtidas de ambas linhagens, infere-se que os suscetíveis usam ambos receptores, dectina-1 e manose, para fagocitar enquanto os resistentes só utilizam o receptor de manose (Ferreira et al. 2007).

Pina et al. (2013) exploraram outros mecanismos que poderiam explicar a resistência e susceptibilidade de camundongos à infecção estudando as DC predominantes e tipos de citocinas associados e descobriram que, quando os camundongos são infectados com $P$. brasiliensis, houve um predomínio de DCs mielóides na medula óssea dos suscetíveis (B10.A) e DCs plasmocitóides nos resistentes (A/J). Também observaram que os camundongos susceptíveis produziram níveis elevados de TNF-a, IL-12, IL-1b e IL-10, ao passo que as DCs dos resistentes produziram concentrações elevadas de TGF- $\beta$ e IL-6 (Pina et al. 2013). Outra característica interessante das DCs dos camundongos resistentes é aumenta a proliferação de linfócitos $\mathrm{T}$ ativados enquanto que os camundongos susceptíveis induzem com maior frequência células CD4+ CD25+ FoxP3+ Treg (Pina et al. 2013). Em outras palavras, as DCs dos resistentes são não somente estimuladores da proliferação de linfócitos, como também das células Treg tolerogênicas.

Recentemente, foi mostrado que a citocina IL-17, desempenha um papel fundamental na defesa antifúngica, e contribui para a resolução da infecção fúngica tal como observado no modelo mais bem estudado de candidíase da mucosa (revisado em Spadari et al. 2007). Durante a infecção por P. brasiliensis, a produção de IL-17 foi observada, e o seu nível foi aumentado em resposta à ausência da ativação de TLR-2, sendo observada uma resposta inflamatória não controlada com baixo número de células reguladoras CD4 + CD25 + Foxp3 +. No entanto, o tempo de sobrevida do hospedeiro não foi afetado pela presença ou não do receptor TLR-2 (Loures et al. 2009).

Outra citocina importante na defesa antifúngica é IL-1 $\beta$, sendo considerada um dos mais importantes mediadores inflamatórios contra fungos oportunistas. Tavares et al. (2013) descobriram que as DCs derivadas de camundongos secreta o dobro de IL-1 $\beta$ que macrófagos 
em resposta à infecção com $P$. brasiliensis, e provavelmente é especialmente reconhecido por NLRP3. Quando este é ativado, ele recruta vários peptídeos para formar o inflamasoma NLRP3 que ativa a caspase-1 e, eventualmente, leva à clivagem de pró-IL-1 $\beta$ a IL-1 $\beta$ (Tavares et al. 2013).

Aparentemente, em PCM, uma resposta Th1 preferencial nos estágios iniciais da infecção seguida de uma resposta anti-inflamatória e imunológica tolerante é fundamental para a resolução da infecção (Thind et al. 2015)

\subsubsection{MACRÓFAgOS}

O macrófago alveolar é provavelmente a primeira célula do sistema imune a interagir com P. brasiliensis e exerce um papel fundamental para sua contenção inicial pelo hospedeiro (Romani 2004, Calich et al. 2008). A importância do sistema mononuclear fagocítico foi evidenciada pelo trabalho de Kashino et al. (1995), que mostrou como o bloqueio deste sistema aumentava a severidade da enfermidade tanto em animais resistentes quanto em susceptíveis.

Brummer et al. (1989) demonstraram que macrófagos alveolares não ativados são capazes de fagocitar as leveduras, tanto in vivo quanto in vitro, mas também podem conferir um ambiente propício para a multiplicação de P. brasiliensis. No entanto, quando os macrófagos são ativados, apresentam ação fungicida ao desintegrarem as estruturas citoplasmáticas e romperem a membrana plasmática; e somente permanece íntegra a parede celular das leveduras (Brummer et al. 1989, Brummer et al. 1990). Para a compreensão do microambiente da ação fungicida dos macrófagos alveolares, estas células de defesa foram analisadas após uma infecção pulmonar em camundongos, e observou-se que a produção de peróxido de hidrogênio encontrava-se ausente nos macrófagos de animais susceptíveis, enquanto era produzido ao longo do curso da infecção pelos macrófagos de animais resistentes (Cano et al. 1995). Embora esteja comprovada que a ativação de macrófagos peritoneais de camundongos por interferon gama (INF- $\gamma$ ) aumenta a atividade fungicida independente de explosão oxidativa (Brummer et al. 1988), o papel do óxido nítrico demonstrou ser fundamental para a habilidade fungicida destas células, que por mecanismo de restrição de ferro inibem a transformação do conídio ingerido em levedura (Cano et al. 
1992, Cano et al. 1994, Gonzalez et al. 2000). Além de seu papel no combate a microrganismos aéreos (Romani et al. 2004), os macrófagos alveolares desempenham um papel no direcionamento da resposta imune adaptativa, que no caso de P. brasiliensis se encontra resumido na Figura 2.3.

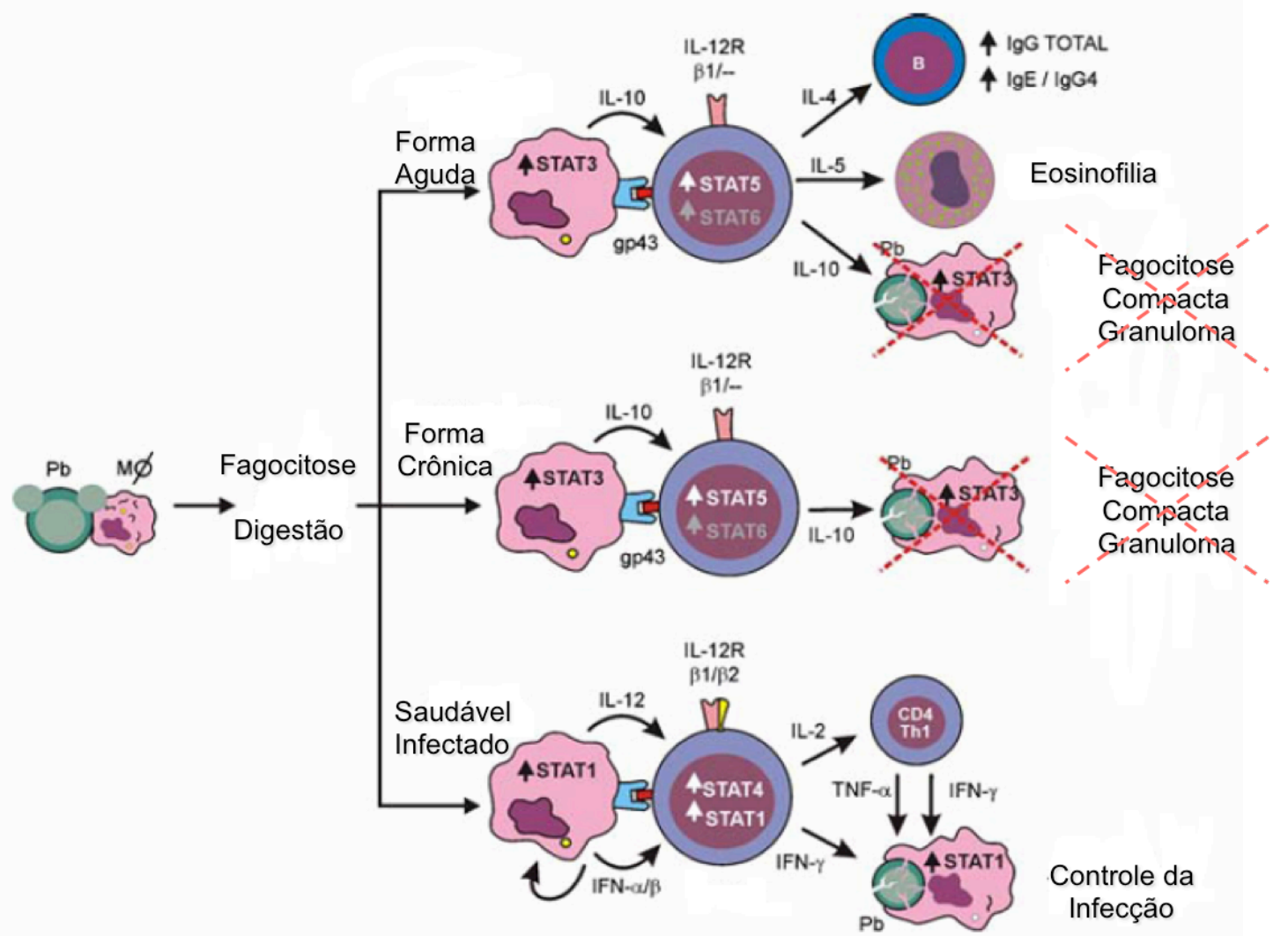

Figura 2.4. Resumo da regulação de citocinas associadas às três principais formas de PCM, baseadas nas respostas imune à glicoproteína $43 \mathrm{kda}$ (gp43), componente antigênico imunodominante da forma leveduriforme de $\boldsymbol{P}$. brasiliensis.

$\mathrm{Pb}$, P. brasiliensis; MØ, macrófago; IL, interleucina; IL-12R, receptor da IL-12; $\beta 1$ e $\beta 2$, subunidades do IL12R; IFN, interferon; TNF, fator de necrose tumoral; STAT, tradutores de sinal e ativadores da transcrição (Benard 2008).

Os macrófagos são conhecidos por seu papel em iniciar e dirigir respostas imunes in vivo. Vários estudos sugerem que diferentes PRRs são utilizados pelos hospedeiros resistentes e susceptíveis para interagir com P. brasiliensis (Almeida et al. 2001, Calich et al. 2008, Pina et al. 2008), e resultam em divergências quanto a apresentação de antígenos, o tipo de imunidade adaptativa e o desfecho da doença. Isto ocorre independente do contexto imunológico inicial (primeiras horas da infecção), e reflete nas bases moleculares dessas diferenças e como esta induz os perfis de PCM descritos.

As principais características dos macrófagos e seus estados de ativação são sua plasticidade e flexibilidade/adaptabilidade ao ambiente. Sua polarização/diferenciação é dirigida por sinais no microambiente do tecido, que inclui citocinas, fatores de crescimento e 
padrões moleculares associados a microrganismos ou danos celulares, provavelmente direcionando a resposta transcricional que moldará o fenótipo e a função desses macrófagos com base no contexto fisiológico ou patológico em questão (Italiani and Boraschi, 2014). Apesar de existirem discussões sobre o espectro no qual um macrófago pode ser ativado, os macrófagos diferenciados são geralmente divididos em dois grupos principais, M1/macrófagos classicamente ativados e M2/macrófagos alternativamente ativados (Mantovani et al. 2005, Murray et al. 2014). Em geral, as células M1 têm um fenótipo de IL$12^{\text {alto }}, \mathrm{IL}-23^{\text {alto }}$, e IL-10 ${ }^{\text {baixo }}$. Por outro lado, as várias formas de macrófagos tipo M2 (M2A, M2a, M2c, M2d TAM) compartilham um fenótipo de IL-12 ${ }^{\text {baixo }}$, IL-23 $3^{\text {baixo }}$, e IL-10 $0^{\text {alto }}$ (Mantovani et al. 2005). Esta plasticidade funcional e reversível é dependente do estado de ativação, que por sua vez é determinado por sinais específicos dos tecidos e microambientes locais (Stout e Suttles 2004, Murray et al. 2014). Neste sentido, existem evidências de que conforme a forma, como, quando e o tipo de condições da diferenciação, os fenótipos M1-M2 irão determinar os resultados/direcionamento, em diferentes vetores, da resposta imune (Figura 2.4).

Por conveniência, como supracitado, as populações de macrófagos são categorizadas em M1 e M2 conforme seu estado de diferenciação (Mantovani et al. 2005, Murray et al. 2014). Tanto as células humanas como as murinas, diferenciadas com CSFs (fator estimulante de colônias), com fator estimulador de colônia de granulócitos-macrófagos (GMCSF) e com fator estimulante de colônias de macrófagos (M-CSF), têm sido utilizadas em alguns estudos de caracterização como modelo. Sua vantagem que ambos fatores apresentam protocolos que render uma maior quantidade de macrófagos que os usados com outros fatores utilizados para polarizar macrófagos (Figura 2.5). O tratamento de monócitos com uma solução contendo GM-CSF origina prioritariamente populações que tendem a produzir níveis elevados de citocinas "pró-inflamatórias" (e.x. TNF, IL-23) e baixos níveis de citocinas "antiinflamatórias" (e.x., a IL-10), características próximas de macrófagos do subtipo M1 (Fleetwood et al. 2007, Verreck et al. 2004, Lancey et al. 2012). Por outro lado, o tratamento com M-CSF tende a originar populações celulares que expressam prioritariamente um repertório de citocinas "anti-inflamatórias" e baixos níveis de citocinas "pró-inflamatórias", características similares a de macrófagos M2 (Fleetwood et al. 2007, Verreck et al. 2004, Lancey et al. 2012). 

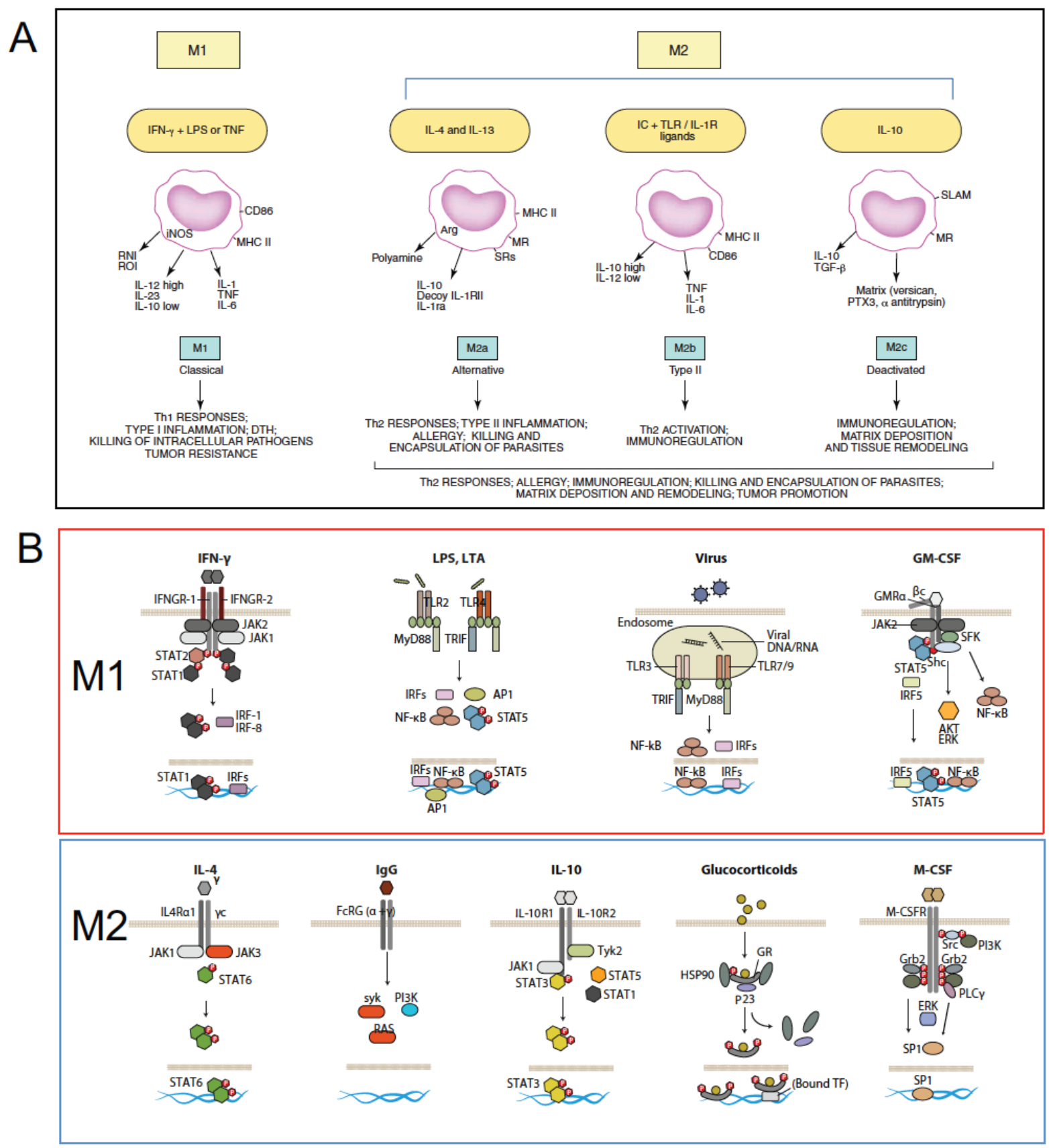

Figura 2.5. O M1/M2 paradigma, a origem e a base molecular (adaptado e revisado em Martinez e Gordon 2014).

(A) Modelo de macrófagos M1-M2, em que M1 incluídos interferon-gama (IFN- $\gamma$ ) + lipopolissacárido (LPS) ou factor de necrose tumoral (TNF) e M2 foi subdividida para acomodar semelhanças e diferenças entre a interleucina-4 (IL-4) (M2a), o receptor (TLR) ligandos complexos imunes + Toll (M2a), e IL-10 e glucocorticóides (M2C). (B) Os receptores e mediadores-chave da sinalização para o fenótipo M1 e M2 em vias comuns e distintas, e inclui fator estimulador de colônia de granulócitos-macrófagos (GM-CSF) e fator estimulante de colônias de macrófagos (M-CSF) como M1 e M2 estímulos.

Sendo assim, essas subpopulações de macrófagos GM-BMM (diferenciadas com GMCSF) e M-BMM (diferenciadas com M-CSF) são rotuladas como "M1-like" e "M2-like", respectivamente, com base apenas no padrão de expressão de citocinas (Fleetwood et al. 2007, Verreck et al. 2004). No entanto, há possibilidade de sobreposição entre essas 
subpopulações. Lacey et al. (2012) consideram a nomenclatura GM-BMM e M-BMM mais propícia, ao em vez de M1/M2, para denotar fenótipos de macrófagos induzidos em resposta a GM-CSF ou M-CSF, pois algumas respostas que induzem a produção de citocinas nestes fenótipos serão diferentes daquelas resultantes a partir das diferentes vias de sinalização ativadas por IFN- $\gamma$, LPS e/ou IL-4, para indução do fenótipo M1/M2 in vitro e in vivo (Figura 2.5).

$\mathrm{Na}$ infecção pulmonar por Cryptococcus neoformans, o estado de polarização dos macrófagos se altera ao longo do tempo devido a re-polarização de macrófagos individuais, ou substituição dos macrófagos M2-polarizados (não protetivos) por células novas M1polarizadas (proteção) (Arora et al. 2011). Davis et al. (2013) demonstraram in vitro que, independente de qualquer estimulação prévia, a polarização de macrófagos é "fenotipicamente e funcionalmente plástica em resposta à alteração de citocinas e à detecção de fungo no ambiente", com o estímulo final determinando o potencial fungicida. Esta plasticidade é provavelmente o mecanismo utilizado por Candida albicans para aumentar a patogenicidade/sobrevivência, alterando sinais ambientais que induzem a mudança de M1 a M2 (Zheng et al. 2013, Reales-Calderón et a. 2014). A re-polarização terapêutica de macrófagos pode abrir a porta para intervenções que possam ser úteis no tratamento de doenças fúngicas (Davis et al. 2013).

Recentemente demostrou-se que receptores que reconhecem resíduos de manose, tais como o receptor de manose (MR), receptor do complemento 3 (CR3) e o receptor tipo Toll 4 (TLR4) nas membranas de macrófagos, podem induzir um direcionamento diferencial no fenótipo de macrófagos de camundongos suscetíveis (B10.A) e resistentes $(\mathrm{A} / \mathrm{J})$ perante a infecção por P. brasiliensis (Feriotti et al. 2013), e podem também estar contribuindo para o perfil de resistência/susceptibilidade na PCM. E, em concordância com a hipótese de resistência/susceptibilidade na resposta ao P. brasiliensis (Calich et al. 2008), a resistência é inicialmente mediada por fagócitos alternativamente ativados (M2) e tolerância ao crescimento de fungos, enquanto que a suscetibilidade está relacionada aos macrófagos classicamente ativados (M1) e o controle eficiente do crescimento fúngico (Feriotti et al. 2013).

Diferente dos macrófagos murinos, os neutrófilos são capazes de eliminar as leveduras de P. brasiliensis por meio de seu metabolismo oxidativo (McEwen et al. 1987, Brummer et al. 1994, Calich et al. 2008). No modelo murino de infecção, ao comparar-se neutrófilos presentes no alvéolo de camundongos suscetíveis (B10.A) com os de 
camundongos resistentes $(\mathrm{A} / \mathrm{J})$, observou-se que os últimos apresentam capacidade fungicida superior, uma consequência de uma atividade oxidativa reforçada (Meloni-Bruneri et al. 1996a, Meloni-Bruneri et al. 1996b). Para macrófagos humanos a presença de TNF- $\alpha$ induz uma capacidade antifúngica contra $P$. brasiliensis melhor que quando comparado ao efeito da exposição ao IFN- $\gamma$ (Kurita et al. 2000), já a capacidade fungicida dos neutrófilos murinos e humanos mostra-se mais exacerbada em resposta às citocinas IFN- $\gamma$, GM-CSF, ou IL1 $\beta$, que quando em presença de TNF- $\alpha$ ou IL8 (Calich et al. 2008).

\subsubsection{CÉlulas NK}

O papel das células NK (Natural Killers) na infecção por P. brasiliensis é complexo e varia de acordo com o tipo de hospedeiro ou local onde estas células foram obtidas (Calich et al. 2008). No sangue periférico de PCM doentes, as células NK foram encontrados em elevado número, mas eles apresentaram atividade citotóxica baixa (Peraçoli et al. 1991), mesmo quando reestimuladas in vitro -com ou sem a adição de IL15- quando comparadas com indivíduos saudáveis (Longhi et al. 2012). Estudos in vitro mostraram que elas tem um efeito inibidor direto no crescimento de P. brasiliensis (Jimenez et al. 1984) e são capazes de reconhecer diretamente e matar células de levedura de $P$. brasiliensis por mecanismo aparentemente grânulo-dependente mas perforina-independente (Longhi et al. 2012). Outro dado importante é que as células NK podem também ter um papel imunomodulador na infecção, já que quando estimuladas são capazes de produzir citocinas IFN- $\gamma$ e TNF- $\alpha$ (Longhi et al. 2012).

\subsubsection{Perfil de Resistência/Susceptibilidade Associados à PCM}

A resistência do hospedeiro humano ou murino à PCM está associada às respostas imunológicas que favorecem a imunidade celular e ativação de fagócitos durante toda infecção, e, apesar de não existir uma resposta polarizada dos padrões Th1/Th2, a secreção de IL12 e IFN $\gamma$ mostra-se protetora (Calich et al. 1998, Calich 2008, Spadari et al. 2004, 
Spadari et al. 2007). Por outro lado, a susceptibilidade está associada à diminuição da resposta imune celular devido à desativação prematura da imunidade mediada por células $\mathrm{T}$ e ativação preferencial de células B, além do aumento de IL-10 ou TGFP (Transforming Growth Factor P) (Calich et al. 1998, Calich 2008).

O grupo da pesquisadora Calich estabeleceu o modelo murino de PCM, o qual mostrou nitidamente que os camundongos B10.A (suscetíveis) e A/Sn ou A/J (resistentes) montam respostas imunes divergentes frente à infeção por $P$. brasiliensis (Calich et al. 1985, Calich et al. 1994, Cano et al. 1995, Calich et al. 1998, Calich et al. 2008). A característica mais importante desses modelos de resistência e suscetibilidade é a semelhança com a forma humana da doença. Os camundongos da linhagem isogênica B10.A imitam as formas crônica, progressiva e disseminada da PCM, enquanto os da linhagem A/Sn ou A/J tem características semelhantes às formas regressiva ou localizada da infecção (Figura 2.5) (Cano et al. 1995, Calich et al. 2008).

Depois de uma infecção intratraqueal (i.t.) com P. brasiliensis, os camundongos suscetíveis (B10.A) são incapazes de restringir a infecção aos pulmões e, dois meses após a infecção, é possível observar a disseminação de $P$. brasiliensis no fígado e no baço; por outro lado, nos camundongos resistentes nenhuma disseminação é observada em outros órgãos (Cano et al. 1995, Calich et al. 2008). Cabe destacar que nas primeiras duas a quatro semanas de infecção, os camundongos B10.A são mais eficientes na eliminação das leveduras de $P$. brasiliensis, o que se mostra evidente pela contagem menor (UFC) no pulmão quando comparado com o número de UFC recuperadas de A/J (Cano et al. 1995, Pina et al. 2008). Depois o padrão muda e os camundongos A/J conseguem eliminar/restringir esta infecção fúngica. 


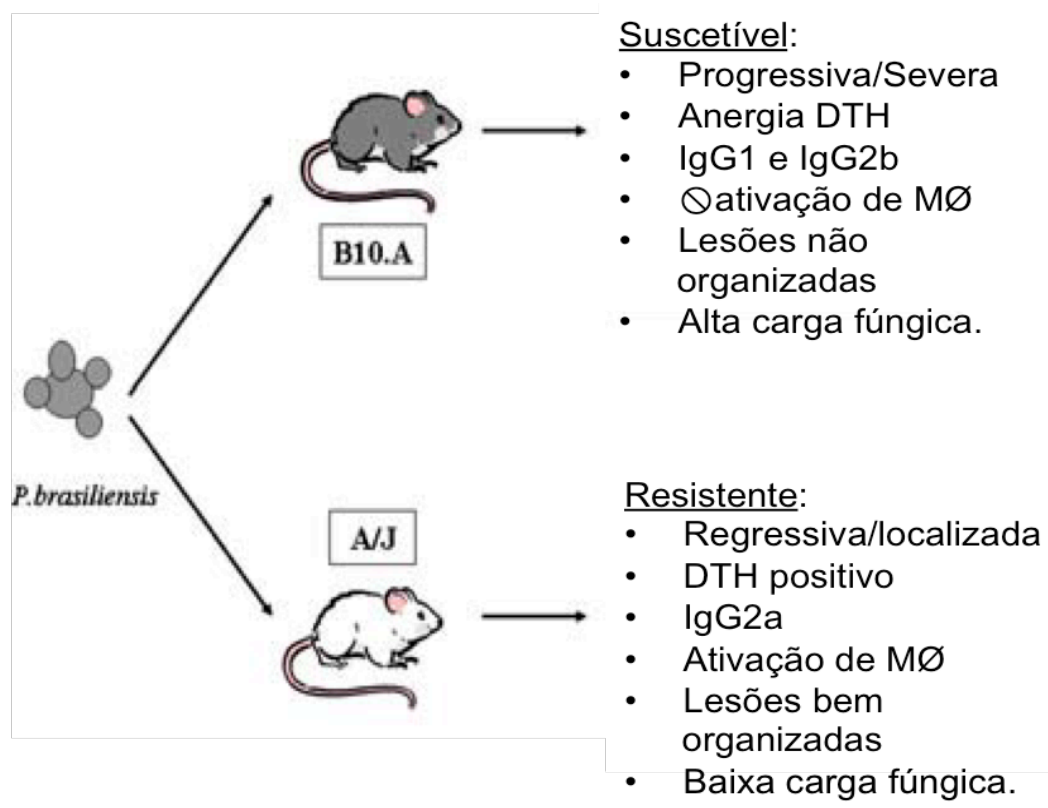

Th2?

Th1

Figura 2.6. Principais características do modelo isogênico murino de resistência e suscetibilidade à infecção pelo fungo Paracoccidioides brasiliensis (Calich et al. 2008).

A hipótese mestra nos modelos de resistência/sucetibilidade é que na fase inicial da infecção, os macrófagos e as células dendríticas de camundongos suscetíveis (B10.A) secretam quantidades elevadas de óxido nítrico (NO) e de IL-12, o que resulta, nos primeiros momentos, na eliminação mais eficaz da carga fúngica (Singer-Vermes et al. 1993, Calich et al. 2008, Pina et al. 2008). Por outro lado, os macrófagos e as células dendríticas oriundos de camundongos resistentes $(\mathrm{A} / \mathrm{Sn}$ ou $\mathrm{A} / \mathrm{J})$ secretam pequenas quantidades de IL-12 associadas a altos níveis de TGF- $\beta$, e resultam em uma secreção deficiente de NO e uma eliminação inadequada da carga fúngica (Singer-Vermes et al. 1993, Calich et al. 2008, Pina et al. 2008). No entanto, estes padrões suaves de ativação culminam em uma ativação mais lenta das células CD4+, tanto Th1 quanto Th2, e das células CD8+ tipo 1, o que induz uma ativação mais eficiente de macrófagos e um processo inflamatório mais controlado a medida que vai progredindo a resposta à infecção.

Já a secreção excessiva de NO nos B10.A terminaria induzindo anergia, eliminação de células T CD4 + e/ou ativação prematura das células Treg, células T reguladoras (Calich et al. 2008). Além disso, a expressão de moléculas co-estimuladoras, tais como CD40 pelas células apresentadoras de antígeno, induz uma ativação preferencial de células T CD8 +, que não é suficiente para ativar os macrófagos e o controle da progressão da infecção (Calich et al. 2008).

Em outras palavras, a suscetibilidade ao P. brasiliensis pode estar associada a uma resposta inata mais eficiente, enquanto a resistência está associada a uma resposta inata 
inicialmente deficiente que permite o desenvolvimento de padrão de resistência no curso da infecção (Pina et al. 2008). O esquema sobre a hipótese dos mecanismos imunológicos inatos e adquiridos que levariam à resistência/suscetibilidade à infecção pelo $P$. brasiliensis pode ser observado na Figura 2.6.

Os estudos in vivo que analisam as diferenças na resposta imunológicas entre as linhagens resistente (A/Sn ou A/J) e susceptível (B10.A) de camundongos sempre avaliam o curso da infecção em relação aos dias de infecção (mínimo com o 1 semana, máximo de 16 semanas) (Calich et al. 1985, Cano et al. 1995). Os diferentes estudos, como já mencionamos, sugerem que os hospedeiros resistentes e suscetíveis utilizam diferentes PRRs para interagir com P. brasiliensis (Almeida et al. 2001, Calich et al. 2008, Pina et al. 2008). O acionamento de diferentes PRRs resultaria na ativação de diferentes vias de sinalização, que por sua vez montaria uma resposta antifúngica diferencial.

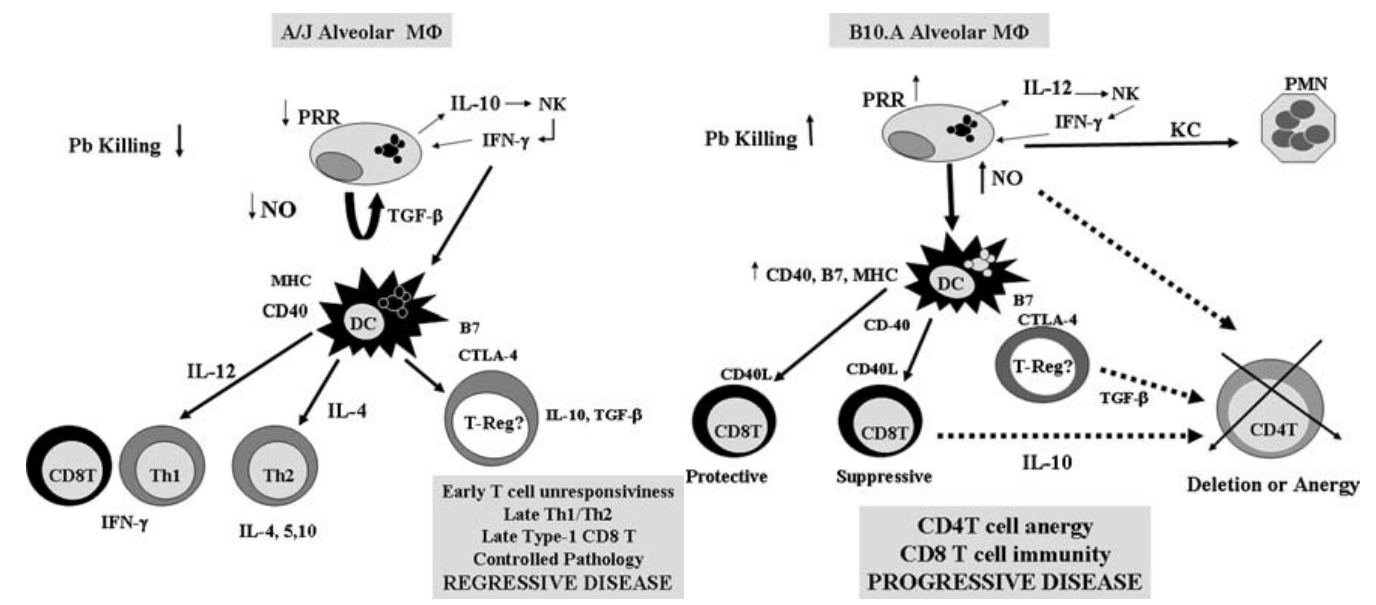

Figura 2.7. Hipótese sobre os mecanismos imunológicos inatos e adquiridos que resultam na resistência/suscetibilidade à infecção por $P$. brasiliensis.

PRR, receptores de reconhecimento de padrão; moléculas co-estimulatórias: CD40, B7, CTLA-4; MHC, complexo maior de histocompatibilidade; $\mathrm{KC}$, quimiocina quimiotática para células PMN; NK, células assassinas naturais; TGF- $\beta$, factor de crescimento de tecido beta; Treg, células T CD4 + reguladoras (Calich et al. 2008).

Como supracitado, P. brasiliensis é fagocitado por macrófagos tanto in vivo como in vitro, mas apenas macrófagos ativados tornam-se fungicidas (Brummer et al. 1989). Recentemente, Feriotti et al. (2013) demonstraram que quando os macrófagos peritoneais de camundongos resistentes $(\mathrm{A} / \mathrm{J})$ e suscetíveis (B10.A) são expostos a leveduras de $P$. brasiliensis, exibem um aumento da expressão de marcadores de diferenciação tipo M2 (Arginase-1, FiZZ1, YM1 e SOCS1) e M1 (iNOS e SOCS3), respectivamente. De fato, e em conformidade com os artigos relacionados, parece que a suscetibilidade à $P$. brasiliensis está associada a uma resposta imune inata inicial exacerbada, mediada pelos macrófagos similares 
à M1 e uma falta de controle do crescimento fúngico. Por outro lado, a resistência está associada a uma resposta inicial pró-inflamatória moderada, mediada por macrófagos alternativamente ativados, que vai desenvolvendo para um melhor controle de carga fúngica nas fases posteriores da infecção. No entanto, estes macrófagos tipo M2 não mostraram os marcadores de diferenciação clássicos (Feriotti et al. 2013).

Para entender melhor a base molecular de resistência/suscetibilidade e o papel dos macrófagos tipo M1/M2, na infecção por P. brasiliensis, foram avaliados no modelo murino de PCM os seguintes parâmetros: habilidades fagocíticas e secretoras dessas células do sistema imune após infecção por $P$. brasiliensis, níveis de transcritos de alguns genes relacionados à resposta antifúngica nos macrófagos diferenciados com GM-CSF (similar à M1) e M-CSF ( similar à M2) obtidos a partir da medula óssea de camundongos resitentes A/J e suscetíveis B10.A e infectados com P. brasiliensis. Também foi realizada uma análise transcritômica em larga escala visando avaliar o padrão de expressão gênica de DCs oriundas de ambas as linhagens de camundongos (A/J e B10.A) após infecção com P. brasiliensis, com o objetivo de melhor compreender o papel dessas células na resistênca/sucetibilidade ao fungo.

\subsection{Análise transcritômica em larga escala em estudos de interação}

A compreensão dos mecanismos de regulação do sistema imune, evasão dos patógenos e as vias pelo qual o hospedeiro estabiliza-se em todos os seus níveis de interação hospedeiro-patógeno - seja bioquímico, protéico e/ou molecular- torna-se essencial para uma visão holística do funcionamento do sistema imune. Essa interação pode resultar em diversas alterações na célula hospedeira, incluindo alterações fenotípicas como os rearranjos do citoesqueleto, e ativação de vias de sinalização celular que podem levar a uma grande reprogramação do transcritoma (Jenner e Young, 2005). Apesar dos mecanismos epigéneticos e pós-transcricionais serem importantes na regulação da resposta celular à infecção, essa regulação ocorre principalmente via modulação dos níveis de RNA (Staudt et al. 2000, Gómez-Díaz et al 2012), e assim tem destaque na resposta do hospedeiro à infecção.

Em patógenos, já foi demonstrado que a plasticidade fenotípica em relação ao contexto do hospedeiro é importante tanto quanto a variação gênica em determinar o sucesso da 
infecção fúngica. Em um estudo no qual a levedura Metschnikowia bicuspidata, que infecta a pulga d'agua Daphnia dentifera, não tem qualquer variação hereditária detectável que impeça uma rápida evolução foi usada para determinar o efeito do genótipo do hospedeiro sobre a infectividade do parasita (Searle et al. 2015). Em outras palavras, é a habilidade de modular a expressão do genoma frente a mudanças no seu contexto que determina a efetividade de organismo de manter sua homeostase interna e sobreviver seu ambiente externo Estudos nessa área de interação parasita-hospedeiro poderão ajudar no desenvolvimento de novas estratégias para prevenção de doenças, assim como a definição de alvos terapêuticos mais eficientes (Yowe et al. 2001, Jenner et al. 2005). Além disso, o entendimento da diferença de como o hospedeiro resistente e o suscetível interagem e respondem ao patógeno poderá também ajudar no desenvolvimento de tratamentos mais eficazes e específicos, o que poderia ajudar a moldar um fenótipo do hospedeiro inicialmente suscetível a um fenótipo de resistência.

Nos anos recentes, diversas metodologias, incluindo "microarranjos" (MA), utilizados para caracterização de transcritomas, e sequenciamento de nova geração (NGS, Next Generation Sequencing) ou sequenciamento em larga escala, como análise em série de expressão gênica (SAGE) e mais recentemente o sequenciamento de mRNA (RNA-Seq) desenvolvidos para a quantificação de transcritos em larga escala (Cummings et al. 2000, Jenner et al. 2005, Wang et al. 2009), vem permitindo a análise simultânea de milhares de genes. Essas metodologias podem fornecer uma compreensão global da evolução temporal que ocorre na transcrição gênica do hospedeiro em resposta à interação com um patógeno.

Por isso, as técnicas de NGS vêm substituindo antigos métodos de sequenciamento de genomas e análises transcritômicas por MA já que, além da versatilidade em termos de aplicações, apresentam alta sensibilidade e reprodutibilidade sem necessidade de conhecimento prévio da sequência (Cloonan et al. 2008, Marioni et al. 2008, Shendure e Ji 2008). Quanto às análises de transcritomas, o RNA-seq apresenta um grande potencial na caracterização de transcritomas complexos, permitindo a determinação de forma quantitativa e precisa dos níveis de transcritos, e permitindo a posterior análise de mRNA e outros tipos de RNA (rRNA, tRNAs, miRNA, e outros RNAs não codantes) no processo global de transcrição de uma célula ou tecido numa determinada condição experimental em grande detalhe (Mortazavi et al. 2008, Shendure e Ji 2008), dado que não apresenta um limite superior para quantificação (large dynamic range) como apresenta os estudos empregando MA que está limitado aos genes pré-selecionados (Wang et al. 2009). Além do mais, por meio da comparação dos resultados do RNA-Seq e de MA com a RT-PCR em tempo real 
(qRT-PCR), ficou demonstrado uma maior concordância dos resultados desta última com o RNA-Seq (Marioni et al. 2008).

O RNA-seq a presenta vantagens em relação à outras metodologias de análises de transcritomas. Como não necessita de conhecimento prévio das sequências investigadas (embora importante na análise dos dados), a identificação de novos transcritos, a caracterização de suas várias isoformas e a caracterização de formas de splicing alternativo podem ser abordadas em processos biológicos complexos, tais como os que ocorrem no sistema imune e no sistema nervoso, como jamais descritos antes por outras metodologias (Lynch et al. 2004, Sultan et al. 2008). Outras vantagens são que sequências semelhantes são diretamente discriminadas pelo sequenciamento; necessita de menores quantidades de RNA; e a quantificação é baseada em um sinal digital, permitindo que a detecção de transcritos seja feita em uma ampla escala de magnitude (Wang et al. 2009, Shendure e Ji 2008). Em resumo, as etapas de uma análise de RNA-seq consistem em isolar todos os RNAs da mostra biológica que se deseja analisar, filtrar o RNA (depleção de rRNA ou seleção por poliA+, ver mais informação a seguir), convertê-los em cDNA, sequenciar os fragmentos de cDNA em um aparelho de nova geração, mapear os fragmentos ao genoma de referência, identificar variações de splicing e isoformas, descobrir novos transcritos e quantificar a expressão de transcritos.

No entanto, também precisamos mencionar que a NGS é uma metodologia em franco desenvolvimento e que ainda apresenta uma série de desafios a serem resolvidos (revisado em Wang et al. 2009). Um primeiro ponto crítico refere-se ao preparo da amostra, mesmo com muitos kits otimizados sendo comercializados, já que um grande número de manipulações a partir da amostra de RNA até a obtenção das bibliotecas de cDNA ainda são necessárias; as grandes moléculas de RNA (como os mRNAs) devem ser fragmentadas antes de serem submetidas ao sequenciamento; e para os transcritomas complexos, a detecção de reads que ultrapassam junções de splicing, provavelmente relacionadas à presença de variantes de splicing, gera uma dificuldade adicional no mapeamento destas sequências (Wang et al. 2009). Outro ponto que influencia as análises dos dados é como selecionar os RNAs de interesse, e para este fim as metodologias mais comumente utilizadas são a seleção positiva de mRNAs (Mortazavi et al. 2008) e a seleção negativa de rRNAs (Li et al. 2013) da mostra de RNA total. A primeira metodologia seleciona os mRNAs por suas caudas poli-A, portanto todas as outras sub-populações de RNA celular que não as contem são perdidas (Mortazavi et al., 2008). Já na segunda, com a depleção de rRNA por sondas específicas todas as demais subpopulações de RNA, tanto os mRNAs como também outros RNAs não 
codantes, na amostra serão incluídas no sequenciamento (Li et al., 2013). Esta seleção de RNAs é necessária para aumentar a cobertura dos RNAs de interesse, já que rRNA é encontrado em grande quantidade na célula e pode subestimar as outras subpopulação (Zhao et al., 2014). Independente da metodologia escolhida, esta deve ser levada em conta na hora da análise. Igualmente importante é a análise de dados, para a qual existe uma série de desafios na bioinformática, como artefatos do processo de sequenciamento, falsos positivos, quantificação imprecisa de genes pouco expressos, entre outros, cujas soluções encontram-se em pleno desenvolvimento, mas que ainda deverão ser resolvidas.

Neste sentido, o emprego do RNA-Seq, mais que qualquer outra metodologia de análise transcritômica em larga escala, vem ao encontro de uma melhor adequação metodológica, conforme proposto neste projeto. Dado que nos permite explorar a diferença transcricional entre a modulação gênica de células da resposta imune inata, células dendríticas, do hospedeiro resistente e suscetível a PCM frente a uma infecção por P. brasiliensis.

Desde o desenvolvimento de metodologias de sequenciamento de alto rendimento de DNA/RNA, a compreensão da regulação gênica transcricional e pós-transcricional aumentou signficativamente (Shendure et al. 2008, Sultan et al. 2008). Além disso, os avanços nos métodos proteômicos e do desenvolvimento de uma infinidade de técnicas inovadores de análise de célula também têm contribuído para a melhor compreensão de vários processos biológicos altamente complexos em uma visão mais holística.

Estas abordagens têm sido aplicadas para detalhar as bases moleculares envolvidas na resposta imune inata, traçando o caminho desde o primeiro evento molecular, como a interação PAMP-PRR, às cascatas de sinalização e regulação transcricional, que em conjunto definem o controle patógeno induzido na expressão genica (Mortazavi et al. 2008, Medzhitov e Horng 2009, Costa et al. 2010, Carpenter e Fitzgerald 2015). Em vista da importância da resposta imune inata, ativar e regular adequadamente uma resposta inflamatória para combater a infecção, é crucial para evitar danos ao hospedeiro, como observado em várias doenças.

Além da enorme quantidade de dados que revelem a importância da regulação transcricional da expressão de genes inflamatórios, existe também mais um passo igualmente importante de regulação, muito menos considerado, que opera em nível pós-transcricional. Carpenter et al. (2014) e O'Connor et al. (2015) enfatizaram em seus trabalhos o papel de splicing alternativo, a estabilidade do mRNA e regulação de tradução, diretamente associado aos componentes da imunidade inata. Esses autores apresentaram vários exemplos de splicing diferencial de TLR e genes da proteína de sinalização, resultando em isoformas 
funcionalmente diferentes, bem como o controle do nível da estabilidade do mRNA e da tradução, proporcionando uma resposta rápida e afinado em sua magnitude e extensão. No total, estes desenvolvimentos recentes destacam a importância irrefutável da coordenação dos mecanismos reguladores que operam nas camadas múltiplas na expressão de genes inflamatórios como o pilar fundamental no controle e na modulação da resposta imune inata do hospedeiro. 


\section{OBJETIVOS}

\subsection{Objetivo Geral}

Compreender as bases moleculares da suscetibilidade do hospedeiro mamífero à infecção por Paracoccidioides brasiliensis, a fim de identificar potenciais alvos terapêuticos e farmacológicos no tratamento dessa micose sistêmica.

\subsection{Objetivo Específico e Metas}

- Caracterizar as diferenças no padrão de expressão de genes do hospedeiro murino (linhagens resistente e suscetível) em resposta à infecção por $P$. brasiliensis.

Metas:

- Caracterizar as diferenças no transcritoma de células dendríticas derivadas da medula óssea de camundongos suscetíveis e resistentes infectados experimentalmente com $P$. brasiliensis, empregado o sequenciamento de mRNA em larga escala (RNA-seq).

- Identificar os genes potencialmente relacionados com a suscetibilidade do modelo murino à infecção fúngica e com a modulação da resposta imune com função protetora, comparando os dados de transcritoma entre linhagens suscetíveis versus resistentes. Validar os dados obtidos por RTPCR em tempo real (qRT-PCR).

- Caracterizar as diferenças no perfil de expressão de genes específicos da resposta antifúngica de macrófagos tipo M1 e M2 derivadas de medula óssea de linhagens de camundongos suscetíveis e resistentes infectados ex-vivo com $P$. brasiliensis, empregado a metodologia de PCRarray.

- Identificar a diferença na modulação de genes relacionados com a imunidade antifúngica entre as subpopulações de macrófagos M1-like e M2-like diferenciadas in vitro a partir de BMDMs de nas linhagens resistentes e suscetíveis de camundongos após infecção com $P$. basiliensis.

- Comparar as diferenças nas modulações entre ambas as linhagens de camundongos (suscetível X resistente).

- Estabelecer a importância da polarização dos macrófagos no modelo murino de resistência e suscetibilidade à paracoccidiomicose. 


\section{MATERIAIS E MÉTODOS}

\subsection{Paracoccidioides brasiliensis}

O microrganismo utilizado neste estudo foi o isolado $\mathrm{Pb} 18$ de P. brasiliensis considerado virulento na literatura (Singer-Vermes et al., 1989), e cuja virulência foi mantida em laboratório por passagens rotineiras do fungo em modelo de infecção animal (infecção intratraqueal em camundongos e re-isolamento do fungo). As passagens eram realizadas com intervalo máximo de três meses, visando prevenir a perda de patogenicidade do isolado $\mathrm{Pb} 18$. Este fungo era cultivado e mantido em meio sólido Fava-Neto (protease peptona $0,3 \%$, peptona $1 \%$, extrato de carne $0,5 \%$, dextrose $4 \%$, extrato de levedura $0,5 \%, \mathrm{NaCl} 0,5 \%$ e ágar 1,6 \%; pH 7,2)(Fava Netto, 1955) a $36,5^{\circ} \mathrm{C}$, e as células leveduriformes eram utilizadas em experimentos após seis a sete dias de crescimento .

Para os procedimentos, as leveduras eram suspensas em tampão fosfato (phosphate buffered saline, PBS) 1X ou meio de cultura RPMI-1640 simples (ver a seguir), agitadas vigorosamente em vortex, para minimizar os agregados de células, e posteriormente decantadas em falcon de $15 \mathrm{~mL}$ para a sedimentação dos grumos restantes. $\mathrm{O}$ número de células viáveis era determinado por contagem em câmara de Neubauer, e a viabilidade do fungo analisada por meio do corante vital verde Janus (Goihman-Yahr et al., 1980), admitindo-se, para uso, uma viabilidade celular mínima de $90 \%$.

\subsection{Linhagens de Camundongos}

As linhagens de camundongo $\mathrm{A} / \mathrm{J}$ (resistente à $P$. brasiliensis) e B10.A (suscetível à $P$. brasiliensis) foram empregadas neste estudo, e são modelo murino

estabelecido de resistência/susceptibilidade para PCM (Calich et al., 1985; Cano et 
al., 1995; Pina et al., 2008; Singer-Vermes et al., 1995). Ambas linhagens também são amplamente usada em pesquisas imunológicas (mais informação sobre o perfil genético da linhagem A/J: https://www.jax.org/mouse-search?searchTerm=A\%2FJ; mais informação sobre o perfil genético da linhagem B10.A: https://www.jax.org/mouse-search?searchTerm=B10.A).

Todos os animais utilizados eram machos, com idade entre 8 a 12 semanas. Matrizes dos animais foram obtidas no Biotério de Camundongos Isogênicos do Departamento de Imunologia do ICB-USP e foram mantidas em condições apropriadas, com fornecimento de água e ração ad libitum, no biotério da Faculdade de Medicina e do Instituto de Biologia da Universidade de Brasília (UnB).

Todos os experimentos realizados com camundongos, tanto os in vivo quanto os ex vivo, delineados a seguir, foram desenvolvidos de acordo com o protocolo aprovado pelo Comitê de Ética no Uso Animal (CEUA) da Universidade de Brasília (UnB), processo (UnBDoc) 52657/2011, ANEXO 1.

\subsubsection{Eutanásia dos camundongos e obtenção de soro}

Os camundongos das linhagens $\mathrm{A} / \mathrm{J}$ e B10.A foram sacrificados por métodos diferentes para obtenção das diversas amostras biológicas (medula óssea e sangue). Para o recolhimento da medula, a eutanásia foi realizada pela inalação de atmosfera saturada por dióxido de carbono. Por outro lado, para a obtenção de sangue do plexo ocular, a eutanásia foi executada por anestesia com uma solução de $20 \%$ de quetamina $10 \mathrm{ng} / \mathrm{mL}$ e $10 \%$ xilazina $20 \mathrm{ng} / \mathrm{mL}$ em PBS via peritoneal- a dose empregada foi $100 \mu \mathrm{L}$ do anestésico para $20 \mathrm{~g}$ do animal da linhagem B10.A e 150 $\mu \mathrm{L}$ do anestésico para $20 \mathrm{~g}$ do animal da linhagem A/J. O soro foi obtido por centrifugação do sangue total a $1000 \mathrm{~g} / 5 \mathrm{~min}$ e aliquotado para uso em tubos eppendorfs de $1,5 \mathrm{~mL}$.

A amostra de medula foi empregada imediatamente em experimentos de diferenciação celular, já as amostras de soro foram armazenadas na temperatura de $20^{\circ} \mathrm{C}$, por no máximo três meses, e utilizadas para opsonização do fungo nos experimentos. 


\subsubsection{Isolamento de células da medula óssea de camundongos}

Os fêmures e tíbias obtidos de camundongos A/J e B10.A foram colocados em meio RPMI-1640 simples em tubos eppendorf de 1,5 mL, um tubo para cada camundongo. Em fluxo laminar, os ossos foram esterilizados em etanol 70\% por três minutos, em seguida abertos e seu conteúdo (medula) lavado com seringa de $20 \mathrm{~mL}$, com agulhas 26G1/2, contendo RPMI-1640 simples gelado. A suspensão das células foi então centrifugada à $300 \mathrm{~g} / 5 \mathrm{~min} / 4^{\circ} \mathrm{C}$ e o pellet ressuspenso novamente em meio RPMI-1640 simples. As células foram contadas em contador de células automático e a suspensão de células, com número de células específico para cada procedimento de diferenciação (ver a seguir), foi centrifugada novamente a $300 \mathrm{~g} / 5 \mathrm{~min} / 4^{\circ} \mathrm{C}$ e ressuspensa no meio específico para diferenciação (ver a seguir). As células da medula óssea não utilizadas imediatamente para diferenciação foram ressuspensas em meio de congelamento ( $90 \%$ soro fetal bovino inativado -SFB- e $10 \%$ DMSO) em alíquotas contendo $4-6 \times 10^{6}$ células e congeladas primeiramente a $-80^{\circ} \mathrm{C}$ em um recipiente de congelamento celular por dois dias e, posteriormente, em nitrogênio líquido por tempo indefinido.

$\Rightarrow$ Preparação de meio RPMI-1640 simples

RPMI 1640 (Sigma-Aldrich) rico em glicose com L-glutamina e HEPES 25 $\mathrm{mM}$ (em pó), foi suplementado com $2 \mathrm{~g}$ bicarbonato de sódio e seu volume ajustado para $1 \mathrm{~L}$ com água destilada. $\mathrm{O}$ meio, então, foi ajustado para $\mathrm{pH}$ 7,2 e filtrado com filtro 0,22 $\mathrm{nm}$ Milipore. Por fim, foi adicionado $50 \mathrm{mg}$ de gentamicina por litro da solução de estoque.

\subsubsection{DifERENCIAÇÃO E INFECÇÃO DE MACRÓFAGOS TIPO M1 (GM-BMMs) E CÉLULAS DENDRÍTICAS (BMDCS)}

Os macrófagos com fenótipo similar ao tipo M1 (GM-BMM) e as células dendríticas (BMDCs) derivadas da medula óssea das linhagens de camundongos A/J (resistente) e B10.A (suscetível) foram obtidos pelo método descrito por Lutz et al. 
(Lutz et al., 1999) com o uso de GM-CSF (Recombinante PEPROTECH cat no: 31503).

$\Rightarrow$ Meio de Diferenciação GM-BMM/BMDCs

O meio RPMI-1640 simples complementado com 20\% SFB inativado, GMCSF $20 \mathrm{ng} / \mathrm{mL}$, e 2-mercaptoethanol (concentração final de $50 \mu \mathrm{M}$ ).

Foram adicionadas $2 \times 10^{6}$ células em $10 \mathrm{~mL}$ de meio de diferenciação GM-BMM em uma placa de Petri, e cada placa foi mantida por oito dias em estufa úmida a $37^{\circ} \mathrm{C}$ e $5 \% \mathrm{CO}_{2}$, sendo suplementada com mais $10 \mathrm{~mL}$ de meio de diferenciação GM-BMM no terceiro dia. No sexto dia, aspirou-se $10 \mathrm{~mL}$ do sobrenadante contendo células, e centrifugou-se à $300 \mathrm{~g} / 15-20 \mathrm{~min} / 4^{\circ} \mathrm{C}$ em RPMI-1640 simples. O pellet foi ressuspendido em $10 \mathrm{~mL}$ de meio de diferenciação GM-BMM e devolvidos para as placas de Petri. No último dia, o sobrenadante contendo as células não aderentes e fracamente aderentes foram centrifugadas $300 \mathrm{~g} / 5 \mathrm{~min} / 4^{\circ} \mathrm{C}$ e o pellet ressuspenso em meio de RPMI-1640 com 10\% SFB. Logo, as células foram contadas e colocadas nas placas destinadas para o ensaio de interação. Dessas células, 75-80\% são BMDCs (avaliar expressão de CD11c, MHCII) imaturas, em sua maioria, com alta capacidade de fagocitar, conforme literatura (Misharin et al. 2013). As células aderentes (GMBMM) foram coletadas usando Cell Dissociation Solution Non-enzymatic 1x (C5914 Sigma) para soltar as células aderidas, a suspenção foi centrifugada $300 \mathrm{~g} / 5 \mathrm{~min} / 4^{\circ} \mathrm{C}$, e o pellet ressuspenso em meio de RPMI-1640 com 10\% SFB, contadas e colocadas nas placas destinadas para o ensaio de interação.

Em seguida, tanto GM-BMM quanto as BMDCs, cultivadas em meio RMPI 1640 com $10 \%$ de soro fetal bovino, foram infectadas com $P$. brasiliensis numa proporção de 5 células para 1 levedura (multiplicity of infection, MOI: 5:1) opsonisada ou não previamente com soro de camundongos (30 min com $20 \%$ de soro) no caso dos GM-BMM- e incubados por $6 \mathrm{~h}$ ou $24 \mathrm{~h}\left(37^{\circ} \mathrm{C}, 5 \% \mathrm{CO}_{2}\right)$. 


\subsubsection{DifERENCIAÇÃo E INFECÇÃo DE MACRÓFAGOS TIPO M2 (M-BMM)}

A obtenção de macrófagos similar ao tipo M2 da medula óssea (M-BMM) de ambas as linhagens de camundongo supracitadas foi realizada segundo o protocolo de Bourgeois et al. (2009).

$\Rightarrow$ Preparação do sobrenadante de cultura de L929

A linhagem celular de fibroblasto L929 (ATCC CCL1), que produz de forma constitutiva M-CSF, foi mantida congelada em nitrogênio líquido em meio de congelamento (90\% SFB inativado e 10\% DMSO). Para cultivo, uma alíquota era descongelada e diluída em meio RPMI-1640 suplementado com $10 \%$ de soro fetal bovino. Essa suspensão era então centrifugada a $300 \mathrm{~g} / 5$ $\min / 4^{\circ} \mathrm{C}$ e o pellet ressuspendido em $20 \mathrm{~mL}$ de RPMI-1640 suplementado com $10 \%$ SFB. Essa suspensão era então cultivada a $37^{\circ} \mathrm{C}$ em estufa úmida e $5 \% \mathrm{CO} 2$ em garrafa de cultura de $150 \mathrm{~cm}^{2}$. Após atingir $100 \%$ de confluência, o meio era retirado e cerca de 100 mL de meio RPMI-1640 sem suplementação era adicionado. As células foram crescidas nessas condições por sete dias e então o sobrenadante da cultura era coletado e filtrado em filtros Milipore de 0,22 $\mathrm{nm}$. O sobrenadante de cultura (LCCM, L929 Cell Conditioned Medium) era então aliquotado e congelado para uso posterior.

$\Rightarrow$ Meio de Diferenciação M-BMM 50\% de meio RPMI-1640 simples, 20\% SFB inativado e 30\% LCCM.

$\Rightarrow$ Meio de Manutenção M-BMM

Meio RPMI-1640 simples suplentado com 10\% SFB inativado e 5\% LCCM.

Foram adicionadas $4 \times 10^{6}$ células em $10 \mathrm{~mL}$ de meio de diferenciação M-BMM em uma placa de Petri, e cada placa foi mantida por sete dias em estufa úmida a $37^{\circ} \mathrm{C}$ e 5\% CO2, sendo suplementada com mais $10 \mathrm{~mL}$ de meio de diferenciação M-BMM no quarto dia. No último dia, a coleta dos macrófagos foi realizada com PBS 1X gelado para soltar as células aderidas, a suspenção foi centrifugada a $300 \mathrm{~g} / 5$ $\min / 4^{\circ} \mathrm{C}$, e o pellet ressuspenso em meio de manutenção M-BMM. As Celulas foram 
contadas e aplicadas nas placas destinadas para o ensaio de interação. As placas foram mantidas em uma estufa úmida a $37^{\circ} \mathrm{C}$ e $5 \% \mathrm{CO}^{2}$ por no mínimo $12 \mathrm{~h}$ antes do ensaio para inativar os macrófagos.

Os macrófagos M-BMM foram infectados com P. brasiliensis no meio especifico de manutenção (Bourgeois et al. 2009), respeitando a proporção de 5 macrófagos para 1 levedura (MOI: 5:1). A levedura foi opsonisada ou não previamente com soro de camundongos (30 min com $20 \%$ de soro), por $6 \mathrm{~h}\left(37^{\circ} \mathrm{C}, 5 \%\right.$ $\left.\mathrm{CO}_{2}\right)$.

\subsection{Desenho Experimental da Infecção Ex-Vivo de Macrófagos (tipo M1 ou M2) e Células Dendríticas Derivados da Medula Óssea de Camundongos A/J e B10.A com P. brasiliensis}

Células GM-BMM, M-BMM e BMDCs de ambas linhagens foram usadas para analisar e comparar a expressão de genes relacionados a infecção fúngica (PCRarray no caso de GM-BMM e M-BMM, e RNAseq no caso de BMDCs), a produção de citocinas e de óxido nítrico (NO), a carga fúngica e o índice de fagocitose recorrente a infecção com $P$. brasilienisis. O esquema a seguir exemplifica a organização experimental usada na infecção de cada linhagem de camundongo:

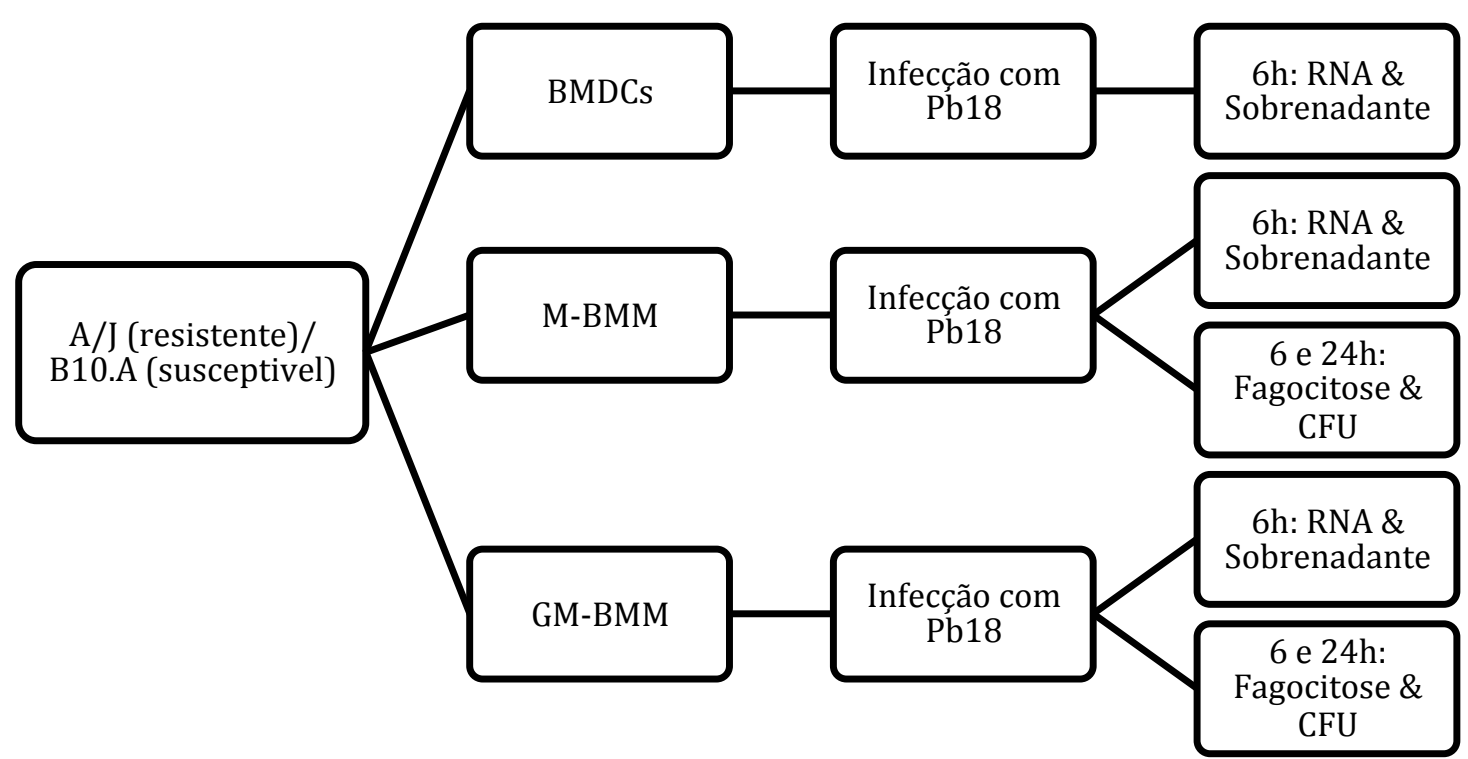




\subsection{Determinação da carga fúngica por contagem das unidades formadoras de colônia (UFC)}

Após o tempo determinado, os fungos não aderidos/internalizados foram removidos por lavagem com meio RPMI-1640 pré-aquecido a $37^{\circ} \mathrm{C}$ e as células foram lisadas com SDS $0.01 \%$ gelado. Subsequente, desse "lisado", $100 \mu \mathrm{L}$ de suas diluições (1:10 e 1:100) foram semeados em placas com meio BHI (Brain Heart Infusion) suplementado (BHI 3,7\%, Glucose $0.8 \%$, soro de cavalo $4 \%$, gentamicina $50 \mathrm{mg} / \mathrm{L} \mathrm{e} 1.5 \%$ Agar). As placas foram incubadas a $37^{\circ} \mathrm{C}$ e a contagem de UFC foi realizada 10 dias após o cultivo inicial das amostras. Os resultados foram expressos como a média do log de UFCs de cada grupo.

\subsection{Análise da internalização de leveduras de $P$. brasiliensis por células derivados da medula óssea de camundongos $\mathrm{A} / \mathrm{J}$ (resistente) e B10.A (suscetível)}

Após 6 e 24 h de infecção, os macrófagos aderidos foram lavados com meio RPMI-1640 simples pré-aquecido a $37^{\circ} \mathrm{C}$ a fim de retirar as leveduras extracelulares ou fracamente aderidas, e em seguida foram fixados e corados com kit de coloração Panótico. Por microscopia óptica, o número de células hospedeiras com leveduras aderidas/fagocitadas foram contadas ao final de cada ponto pós-infecção (total de 300 fagócitos avaliados). Os experimentos foram realizados em triplicata, sendo analisados entre cinco a dez campos microscópicos.

\subsection{Dosagem de Citocinas por ELISA}

Os sobrenadantes das células em cultura foram centrifugados a $1200 \mathrm{~g} / 5 \mathrm{~min}$ para retirada de leveduras e estocados a $-80^{\circ} \mathrm{C}$. Para a dosagem das citocinas, estas 
amostras foram descongeladas e homogeneizadas em vortex. Sendo assim, as citocinas TNF- $\alpha$ (fator de necrose tumoral alfa), IL1 $\beta$ (interleucina 1 $\beta$ ), IL6 (interleucina 6), IL10 (interleucina 10), IL12 (interleucina 12), IL17A (interleucina 17A), IL23 (interleucina 23) e a quimiocina MCP-1 (CCL2) foram dosadas por meio do kit de ensaio de ELISA Ready-SET-Go!® da eBioscience, conforme recomendações no manual do fabricante, sendo que os volumes relatados no protocolo foram reduzidos à metade. A leitura foi feita no espectrofotômetro (SepectraMax M5 - Molecular Devices) e os dados foram analisados com o software SoftMax 5.2. As concentrações de citocinas e quimiocinas foram determinadas por meio de uma curva padrão. Todas as determinações foram realizadas em triplicata.

\subsection{Dosagem Indireta de Óxido Nítrico}

A produção de óxido nítrico $\left(\mathrm{NO}_{2}{ }^{-} / \mathrm{NO}_{3}{ }^{-}\right)$nos sobrenadantes das células em cultura foi determinada pela reação colorimétrica de Griess. O reagente de Griess foi preparado no momento da execução do experimento, por meio da mistura de volumes iguais de $0,1 \%$ de nafitiletilenodiamida (NEED, Sigma-Aldrich, St. Louis, MO, EUA) em água destilada e 1\% de sulfanilamida (Sigma-Aldrich, St. Louis, MO, EUA) em solução aquosa de $5 \% \mathrm{H}_{3} \mathrm{PO}_{4}$. A concentração de $\mathrm{NO}_{2}$ foi determinada por leitura da densidade ótica a $550 \mathrm{~nm}$ em referência ao padrão da solução de $\mathrm{NaNO}_{2}$ - a curva padrão foi feito com diluições seriadas a partir de $200 \mathrm{mM}$ de $\mathrm{NaNO}_{2}(200$ a 3,125 $\mu \mathrm{M})$. As dosagens foram realizadas em triplicata.

\subsection{Análise Estatística nos estudos de produção de citocina/quimiocina e óxido nítrico.}

As diferenças entre os grupos foram analisadas pelo teste $t$ de Student ou por Análise de Variância bifatorial (Two-way ANOVA) ajustada por pós-teste de Tukey 
para comparações múltiplas realizada utilizando GraphPad Prism 6.0d Mac, GraphPad Software, La Jolla Califórnia EUA, www.graphpad.com, conforme o delineamento experimental. O nível de significância adotado foi de 5\%.

\subsection{Extração de RNA Total}

O RNA total das células, tratado com DNAse I, foi obtido empregando-se o RNAeasy ${ }^{\circledR}$ Plus Mini Kit (QIAGEN Cat. No. 74134), segundo protocolo do fabricante.

\subsection{Síntese de cDNA}

Após tratamento com DNAse I (incluído no RNAeasy ${ }^{\circledR}$ Plus Mini kit), a primeira fita de cDNA foi sintetizada a partir de $500 \mathrm{ng}$ de RNA total de cada amostra, quantificado previamente utilizando-se o aparelho Qubit ${ }^{\circledR}$ 2.0 Fluorometer (Life Technologies). A essa quantidade de RNA total adicionou-se $0,5 \mu \mathrm{g}$ do iniciador OligodT $_{18}$ e a mistura foi incubada a $70^{\circ} \mathrm{C}$ por $10 \mathrm{~min}$, seguido de resfriamento imediato por incubação no gelo por cerca de um minuto. À amostra adicionou-se o MIX, para um volume final de $25 \mu \mathrm{L}$, contendo os seguintes reagentes em suas concentrações finais: tampão da transcriptase reversa 1X; 8 mM DTT; 0,4 mM dNTPs; 20 U RNAse Out (Invitrogen). Em seguida, a reação de polimerização foi realizada por incubação a $42^{\circ} \mathrm{C} / 2 \mathrm{~min}$, e posteriormente, $200 \mathrm{U}$ da enzima transcriptase reversa (SuperScript III, Invitrogen) foi adicionada ao sistema, e qual foi mantido novamente a $42^{\circ} \mathrm{C}$ por mais uma hora. A seguir, a enzima foi inativada por aquecimento a $70^{\circ} \mathrm{C}$ por $20 \mathrm{~min}$. 


\subsection{Desenho dos Oligonucleotídeos para qRT-PCR}

Foram desenhados oligonucleotídeos específicos, pelo nosso grupo de pesquisa da UnB (Silva et al. 2008), para os genes MyD88, NF- $\kappa B$, TNF- $\alpha$ e IL1 $\beta$ de Mus musculus. Tais desenhos basearam-se nas sequências obtidas da base de dados do transcritoma de camundongo (http://www.informatics.jax.org) utilizando-se o programa Primer Express (Applied Biosystems). As sequências dos iniciadores estão descritas na Tabela 4.1.

Tabela 4.1. Dados gerais dos oligonucleotídeos sintetizados.

\begin{tabular}{|c|c|}
\hline Gene & Sequência de nucleotídeos $\left(5^{\prime} \rightarrow 3^{\prime}\right)$ \\
\hline \multirow[t]{2}{*}{ MyD88 } & myd88f: ACTGGCCTGAGCAACTAGGA \\
\hline & myd88r: CGTGCCACTACCTGTAGCAA \\
\hline \multirow[t]{2}{*}{ Nfkb1 (p105) } & nfkbf: AGCCAGCTTCCGTGTTTGTT \\
\hline & nfkbr: AGGGTTTCGGTTCACTAGTTTCC \\
\hline \multirow[t]{2}{*}{ TNFa } & tnf f: GTACCTTGTCTACTCCCAGGTTCTCT \\
\hline & tnf r: GTGGGTGAGGAGCACGTAGTC \\
\hline \multirow[t]{2}{*}{ IL1及 } & il1betaf: GTGTGTGACGTTCCCATTAGACA \\
\hline & illbetar: CAGCACGAGGCTTTTTTGTTG \\
\hline \multirow[t]{2}{*}{ TLR2 } & toll2f: AAGAGGAAGCCCAAGAAAGC \\
\hline & toll2r: CGATGGAATCGATGATGTTG \\
\hline
\end{tabular}

As sequências dos oligonucleotídeos para os genes IL6, IL10, IL12 ap35 e CXCL10 foram obtidas do banco de dados PrimerBank http://pga.mgh.harvard.edu/primerbank/ (Spandidos et al. 2010), e suas características estão descritas na Tabela 4.2.

Tabela 4.2. Dados gerais dos oligonucleotídeos do primerbank.

\begin{tabular}{|c|c|}
\hline Gene & Sequência de nucleotídeos $\left(5^{\prime} \rightarrow 3^{\prime}\right)$ \\
\hline IL6 & $\begin{array}{l}\text { il6r: TTGGTCCTTAGCCACTCCTTC } \\
\text { il6f: TAGTCCTTCCTACCCCAATTTCC }\end{array}$ \\
\hline IL10 & $\begin{array}{l}\text { il10r: CGCAGCTCTAGGAGCATGTG } \\
\text { il10f: GCTCTTACTGACTGGCATGAG }\end{array}$ \\
\hline 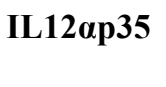 & 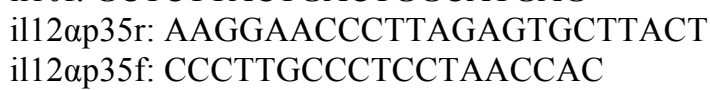 \\
\hline CXCL10 & $\begin{array}{l}\text { 5' CXCL10f: GGCTCGCAGGGATGATTTCAA } \\
\text { 3' CXCL10r: CCAAGTGCTGCCGTCATTTTC }\end{array}$ \\
\hline
\end{tabular}

Para a determinação da polarização dos macrófagos usados foram utilizados oligonucleotídeos específicos para iNOS e arginase I (providos por Dra. Anamélia Bocca-LIA/UnB), e suas seqüências estão descritas na tabela 4.3. 
Tabela 4.3. Dados gerais dos oligonucleotídeos sintetizados.

\begin{tabular}{cl}
\hline Gene & \multicolumn{1}{c}{ Sequência de nucleotídeos (5' $\rightarrow$ 3') } \\
\hline iNOS & iNOSf - CGAAACGCTTCACTTCCAA \\
& iNOSr - TGAGCCTATATTGCTGTGGCT \\
\multirow{2}{*}{ ArgI } & ArgIf - GTTCCCAGATGTACCAGGATTC \\
& ArgIr - CGATGTCTTTGGCAGATATGC \\
\hline
\end{tabular}

O controle interno empregado nos experimentos de qRT-PCR foi o gene RPS9 (40S ribosomal protein $S 9$ ), que codifica para uma proteína da subunidade menor do ribossomo, e cuja expressão é constitutiva e não diferencial entre as condições controle e infectados com P. brasiliensis (Silva et al. 2008, Tavares et al. 2012). Os oligonucleotídeos desenhados para o gene RPS9 estão listados na Tabela 4.4 abaixo:

Tabela 4.4. Dados gerais do controle interno.

\begin{tabular}{ll}
\hline Gene & Sequência de nucleotídeos $\left(\mathbf{5}^{\prime} \rightarrow \mathbf{3}^{\prime}\right)$ \\
\hline RPS 9 & 5' rps9f: CGCCAGAAGCTGGGTTTGT \\
& 3' rps9r: CGAGACGCGACTTCTCGAA \\
\hline
\end{tabular}

A eficiência de reação destes primers foram analisados e são suficientes para serem utilizados usados pelo método $2^{-\Delta \Delta \mathrm{CT}}$ (Livak e Schmittgen, 2001), discutido no item 4.14 .

\subsection{PCR Quantitativo em Tempo Real (qRT-PCR)}

Uma alíquota correspondente a 1/5 da reação de síntese de cDNA foi submetida à reação de amplificação em tempo real, cujo volume final era de $10 \mu \mathrm{L}$, contendo: 5 $\mu \mathrm{L}$ de $\operatorname{SyBr}{ }^{\circledR}$ Green Máster Mix (Applied Biosystems); 0,2 $\mu \mathrm{M}$ de cada oligonucleotídeo (forward e reverso) específico (Tabela 1 ao 4). Foram utilizados como controle interno os oligonucleotídeos que amplificam o gene RPS9 (Tabela 4). As condições de ciclagem foram as programadas para o reagente $\operatorname{SyBr}{ }^{\circledR}$ Green: 
Ciclagem:

(1) $50^{\circ} \mathrm{C} / 2 \mathrm{~min}$

(2) $95^{\circ} \mathrm{C} / 5 \mathrm{~min}$

(3) $95^{\circ} \mathrm{C} / 3 \mathrm{seg}$

(4) $60^{\circ} \mathrm{C} / 30 \mathrm{seg}$

(5) Repetir (3) e (4) quarenta vezes.
Curva de Dissociação:

(1) $95^{\circ} \mathrm{C} / 15 \mathrm{~min}$

(2) $60^{\circ} \mathrm{C} / 1 \mathrm{~h}$

(3) $95^{\circ} \mathrm{C} / 15 \mathrm{~min}$

Todas as amplificações foram feitas no equipamento 7500 Fast Real-Time PCR System (Applied Biosystems).

\subsection{Análise da Resposta Antifúngica por PCRarray}

Após a análise quantitativa (Qubit ${ }^{\circledR}$ 2.0 Fluorometer - Life Technologies) e qualitativa (análise em gel de agarose 0.8\%) do RNA total dos GM-BMM e M-BMM de ambas linhagens murinas, $1 \mu \mathrm{g}$ foi transcrito de forma reversa em cDNA utilizando o $\mathrm{RT}^{2}$ First Strand Kit (SABiosciences), de acordo com o protocolo do fabricante. Subsequentemente, as amostras de cDNA foram marcadas com $\mathrm{RT}^{2}$ Real Time SYBR ${ }^{\circledR}$ Green PCR Master Mix (SA Biosciences) e adicionadas a placas de 96 poços do Mouse Antifungal Response RTC ProfilerTM PCR Array (PAMM 00147Z, SABiosciences/Quiagen).

Este array identifica o acúmulo de transcrito de 84 genes envolvidos na resposta imune inata de fungos patogênicos, que incluem os Receptores de Reconhecimento Padrão (PRRs) e sua via de transdução de sinal associada, e também aqueles cuja expressão influencia os processos inflamatórios e a fagocitose. Além destes, cinco genes housekeeping para a normalização dos dados de PCR e poços para análise de: controle de contaminação de DNA genômico, a eficiência da transcrição reversa e o desempenho PCR estão incluídos no array.

Em nossas condições experimentais, os genes constitutivos B2M e GUSB tiveram níveis de mRNA constantes entre os grupos controle e experimental e foram utilizados para a normalização de dados. O produto de amplificação, a aquisição de dados (obtidos como valores de ciclo limiar $(\mathrm{Ct})$ ) e a curva de fusão foram realizados pelo sistema ABI 7500 qRT-PCR (Applied Biosystems, software de versão 2.0.3). Os 
dados foram analisados por $\mathrm{RT}^{2}$ PCR Array Data Analyses profile versão 3.5 disponível em http://pcrdataanalysis.sabiosciences.com/pcr/arrayanalysis.php

\subsection{Análise Estatística da Expressão dos Genes (qRT-PCR e PCRarray)}

As diferenças na expressão genética entre grupos controle e experimental, tanto para qRT-PCR quanto para PCRarray (usando o software supracitado), foram determinadas usando o método comparativo limiar, cuja quantidade do alvo é normalizada a uma referência endógena e relativa a um calibrador dada pela fórmula aritmética $2^{-\Delta \Delta \mathrm{CT}}$ (Livak e Schmittgen, 2001). Os genes modulados significativamente foram identificados com base em dois critérios: (i) a diferença em valores médios da duplicata de $2^{-\Delta \Delta \mathrm{Ct}}$ foi maior do que 2 ou menor do que -2 (indicativo de regulação positiva ou negativa, respectivamente); e, (ii) a diferença entre os valores em duplicata de $2^{-\Delta \Delta C t}$ para cada gene foi estatisticamente significativa $(p<0,05)$ de acordo com o teste $t$ de Student entre o grupo controle e os grupos experimentais.

\subsection{Preparo das Amostras para RNA-Seq, Sequenciamento e Análise dos Dados}

Após a análise de qualidade (Bioanalyser 2100 - Agilent) e quantificação (Qubit® 2.0 Fluorometer - Life Technologies) do RNA total de cada experimento, 3,5-6,0 $\mu \mathrm{g}$ de RNA total de BMDCs das diferentes condições experimentais foram preparadas para o transporte estável à temperatura ambiente com o RNAstable kit (Biomatrica cat no. 93221-001), conforme as recomendações do fabricante. Estas amostras de RNA foram liofilizadas em tubos plásticos com bomba de vácuo à temperatura ambiente. As amostras seca foram enviadas ao Scripps Research Institute para o sequenciamento. As amostras das diferentes condições experimentais foram nomeadas de acordo com esta lista: 
$\mathbf{A} / \mathbf{J}-1$, 2, ou 3: RNAs das replicatas biológicas de BMDCs de $\mathrm{A} / \mathrm{J}$ nãoinfectadas

A/J+Pb18-1, 2, ou 3: RNAs das replicatas biológicas de BMDCs de A/J infectadas com $\mathrm{Pb} 18$

B10.A-1, 2, ou 3: RNAs das replicatas biológicas de BMDCs de B10.A nãoinfectadas

B10.A+Pb18- 1, 2, ou 3: RNAs das replicatas biológicas de BMDCs de B10.A infectadas com $\mathrm{Pb} 18$.

O sequenciamento em larga escala (RNAseq) foi executado na plataforma HiSeq $2000 \quad$ Analyser da Illumina (http://www.scripps.edu/california/research/ngs/sample.html). Os parâmetros para a construção das bibliotecas e sequenciamento pela geração de reads de 100 bp foram realizados na Scripps DNA Sequencing Facility, sendo as principais etapas e os principais parâmetros de sequenciamento descritos a seguir:

- Preparo das bibliotecas com a tecnologia barcode: a partir de 1-3 $\mu$ g de RNA total, empregando a seleção de RNA poli (A)+, de acordo com o kit Illumina TruSeq RNAseq prep methodology; foram montadas 12 bibliotecas à partir dos RNAs totais de BMDCs, obtidas das linhagens resistente (A/J) e suscetível (B10.A), infectadas ou não por P. brasiliensis, conforme o desenho experimentais descrito anteriormente.

- Características das sequências (Reads type): 2 x 100 paired-end;

- Cobertura do sequenciamento: para um conjunto de 24 amostras a serem enviadas para o sequenciamento (12 amostras referentes ao projeto aqui descrito e as outras 12 referentes a outros projetos de nosso grupo - todos os projetos consistindo de quatro grupos experimentais e cada um com suas triplicatas biológicas), a estratégia empregada utilizou oito amostras/lane e um total de três lanes (cada uma das triplicatas de cada uma das oito diferentes condições experimentais/lane).

- Análise da corrida de sequenciamento: foi utilizado o Genome Analyzer Pipeline Software (Casava v1.9) para fazer uma análise inicial da corrida de 
sequenciamento. O programa faz a análise de imagem, chamada base e demultiplexing dos códigos de barras de dado.

A obtenção e análise dos dados transcritômicos foram realizadas sob coordenação dos responsáveis pela equipe de Bioinformática associada ao Projeto Pronex/FAPDF/CNPq - Edital 03/2009 (Processo 193.000.571/2009): a Profa. Dra. Maria Emília Telles Walter (CIC/UnB), o Dr. Roberto Togawa (Embrapa/Cenargen Brasília), a Dra. Tainá Raiol de Alencar e o Dr. Daniel Paiva Agustinho. O processamento dos dados empregou servidores apropriados e foram executados programas livres de forma sequencial (pipeline). A sequência dos programas empregados na análise dos dados de RNA-Seq estão representados na Figura 4.1.

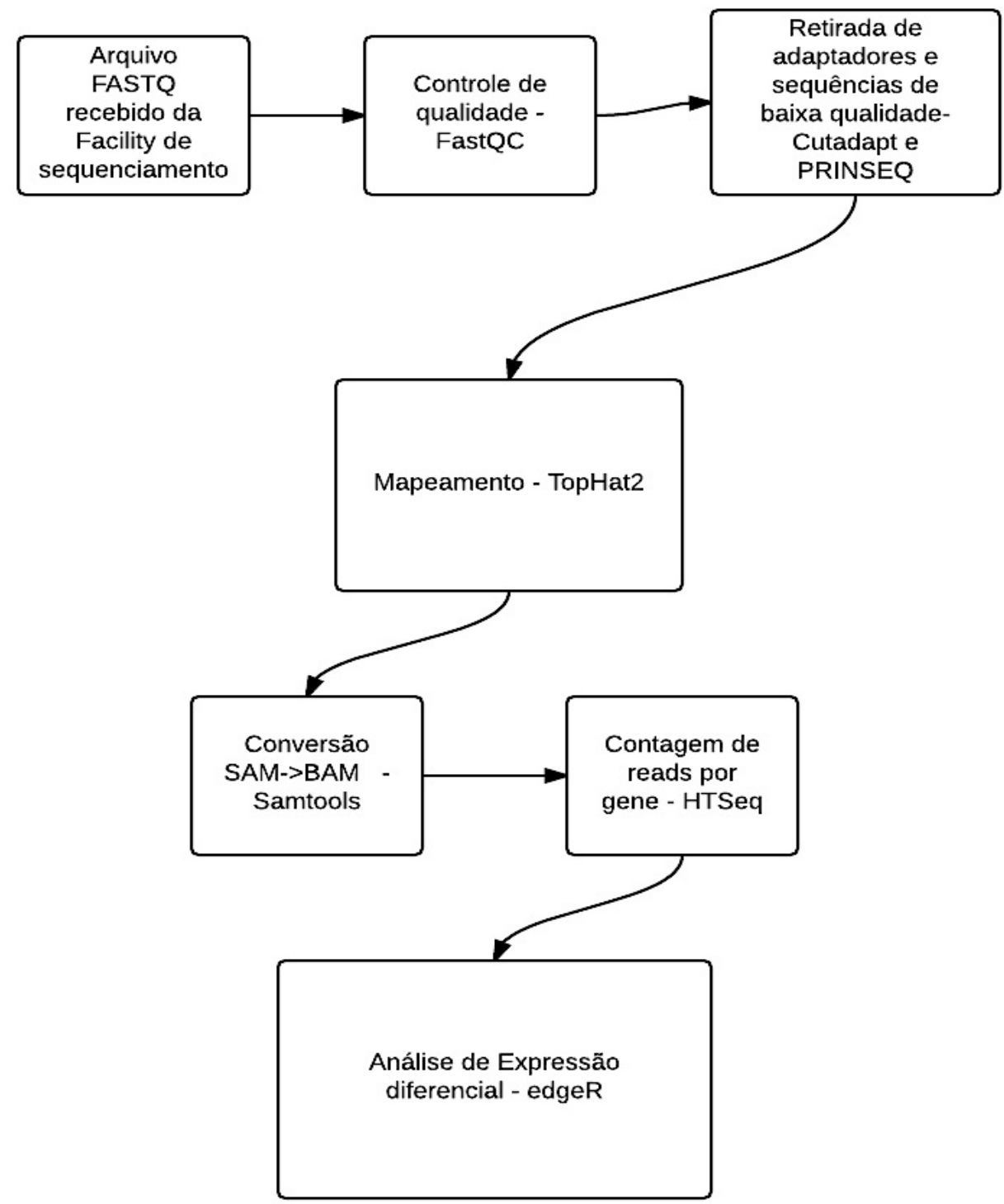

Figura 4.1. Pipeline de análise empregado para análise dos dados de RNA-seq. 
Os resultados do sequenciamento foram obtidos no formato de arquivos FASTQ (Cock et al., 2010). Uma vez em posse desses dados, os arquivos foram avaliados pelo software FastQC (Andrews, 2010). Esse programa analisa as reads (fragmentos de sequenciamento) com relação ao tamanho, qualidade dos dados, presença de contaminações ou adaptadores. Em seguida, os adaptadores encontrados pelo FastQC são retirados pelo software Cutadapt (Martin, 2011), enquanto as sequências de baixa qualidade são retiradas com o PRINSEQ (Schmieder and Edwards, 2011).

Uma vez que as sequências de baixa qualidade e os adaptadores foram removidos, as reads resultantes foram mapeadas no genoma murino mm10 (Mouse ENCODE (Flicek et al. 2012; http://ucscbrowser.genenetwork.org/), utilizando TopHat2 (versão 2.0.11 e Bowtie versão 2.1.0) (Kim et al., 2013). Os arquivos finais deste mapeamento, os arquivos BAM, foram convertidos em um formato mais acessível para as etapas posteriores com o Samtools (Li et al., 2009). Esses arquivos podem ser então utilizados pelo programa HTSeq (Anders et al., 2014), que realiza a contagem das reads por gene obtidas da etapa anterior, produzindo uma tabela que pode então ser utilizada pelo pacote edgeR (Robinson et al., 2010), que realiza os testes estatísticos para determinar os genes diferencialmente expressos.

Os resultados de alguns transcritos de interesse tiveram seu padrão de expressão validado por qRT-PCR, de acordo com as condições de rotina de nosso laboratório, descrito anteriormente. Todos os genes diferencialmente expressos entre as células controle e infectadas com $\mathrm{Pb} 18$ das linhagens $\mathrm{A} / \mathrm{J}$ e B10.A de camundongos foram submetidos a análise de enriquecimento de Gene Ontology (GO) e das vias de KEGG (Kyoto Encyclopedia of Genes and Genomes) usando ferramenta de anotação funcional DAVID 6.7 (http://david.abcc.ncifcrf.gov/). Os resultados foram filtrados com base numa metodologia estatística Fisher Exact semelhante ao que foi anteriormente descrito (Huang et al. 2009). 


\section{RESULTADOS E DISCUSSÃO}

Apesar dos avanços na medicina, as doenças infecciosas continuam a ser uma das maiores preocupações locais e mundiais na área de saúde. Portanto, a necessidade de uma compreensão melhor da relação patógeno-hospedeiro, bem como das diferenças que conferem resistência/suscetibilidade do hospedeiro a um dado parasita, pode contribuir tanto para a definição da melhor modalidade de tratamento, quanto para o desenvolvimento de estratégias terapêuticas e o estabelecimento de novos alvos terapêuticos. Outro aspecto relevante e cujos estudos na área podem auxiliar refere-se ao desenvolvimento de mecanismos que contribuam para a prevenção de uma resposta imune debilitada do hospedeiro decorrente da terapia adotada, como por exemplo o que ocorre na Síndrome de Reconstituição Imune -SRI/IRS (Perfect et al. 2012). Isto é, uma ativação exacerbada ou desregulada do sistema imune devido ao tratamento e que resulta em danos ao hospedeiro, podendo levar à morte (Perfect et al. 2012). Nesse sentido, a identificação do tipo da resposta imunológica do hospedeiro frente ao patógeno não suficiente. A intensidade desta resposta também mostra-se bastante informativa na tentativa de desenvolvimento de estratégias terapêuticas. Adicionalmente, a identificação de genes específicos que desempenham papel fundamental na resistência ou suscetibilidade do hospedeiro ao estabelecimento de uma dada doença pode sugerir novos alvos terapêuticos.

Entretanto, apesar da importância de identificação de novos alvos terapêuticos, até o presente momento somente três estudos focaram na descrição do padrão de expressão de genes relacionados ao sistema imune inato do hospedeiro quando o mesmo foi submetido à infecção ex vivo por P. brasiliensis (Silva et al. 2008, Oliveira et al. 2010, Tavares et al. 2012. Tais estudos investigaram a resposta: de células dendríticas murinas - sentinelas e principal orquestradora do sistema imune (Tavares et al. 2012), de pneumócitos do tipo II humanos imortalizadas - também sentinelas e moduladoras do sistema imune (Oliveira et al. 2010) e de macrófagos peritoneais murinos - sentinelas, moduladoras e células efetoras do sistema imune (Silva et al. 2008) frente à infecção por P. brasiliensis, sugerindo a importância de alguns genes durante a interação dessas células hospedeiras com o fungo. Nenhum deles, porém, 
analisou o efeito da resistência ou suscetibilidade intrínseca do hospedeiro à infecção por P. brasiliensis.

Os estudos sobre resistência/suscetibilidade na PCM têm focado basicamente nas análises imunológicas, ou seja, perfil de citocinas, identificação de receptores celulares, ensaios de fagocitoses, carga fúngica, entre outros (Ferreira et al. 2007, Pina et al. 2008). Nesta sessão, descreveremos as análises do perfil de expressão de genes da resposta imune inata (e outros análises complementares) de células dendríticas (Parte I) e de macrófagos (Parte II -artigo publicado) derivados da medula óssea das linhagens de camundongos resistentes $(\mathrm{A} / \mathrm{J})$ e suscetíveis (B10.A) à infecção ex-vivo por P. brasiliensis.

\subsection{Parte I: Análises de Comparativos de BMDCs de Cultura Primária de Camundongos Resistentes e Suscetíveis à Infecção por P. brasiliensis}

\subsubsection{Análise transcritômica em larga escala (RNA-Seq) da expressão gênica de $m R N A$ de BMDCs provenientes de hospedeiros murinos resistentes e susceptiveis à PCM}

Tendo em vista a importância já relatada das células dendríticas no orquestramento da resposta imunológica, esse trabalho analisou o acúmulo de transcritos de células dendríticas derivadas de medula óssea (BMDCs) originárias de camundongos resistentes $(\mathrm{A} / \mathrm{J})$ e suscetíveis $(\mathrm{B} 10 . \mathrm{A})$ à $\mathrm{PCM}$ quando infectados por $P$. brasiliensis. Os experimentos para obtenção de amostras de RNA total, as quais foram enviadas para sequenciamento em larga escala (RNAseq), foram realizados em triplicatas biológicas independentes, com o objetivo de caracterizar o transcritoma de BMDCs de camundongos das linhagens A/J e B10.A, infectadas ou não com o isolado $\mathrm{Pb} 18$ do fungo. A qualidade do RNA total extraído, após o tratamento com DNAse I, foi analisada via plataforma Bioanalyzer 2100 (Agilent) e o valor de RIN (RNA Integrity Number - ferramenta de software projetada para estimar a integridade das amostras de RNA total, independente da concentração, instrumento e analista. A 
integridade é dada não somente pela razão das bandas ribossômicas, mas por totalidade electroforética do RNA da amostra, que inclui a presença ou ausência de produtos de degradação. Schroeder et al. 2006) para todas as amostras variou entre 7.80 e 8.80. Vale ressaltar que valores de $\mathrm{RIN}>7,00$ são tidos como ideais para experimentos de RNA-seq (Figura 5.1).

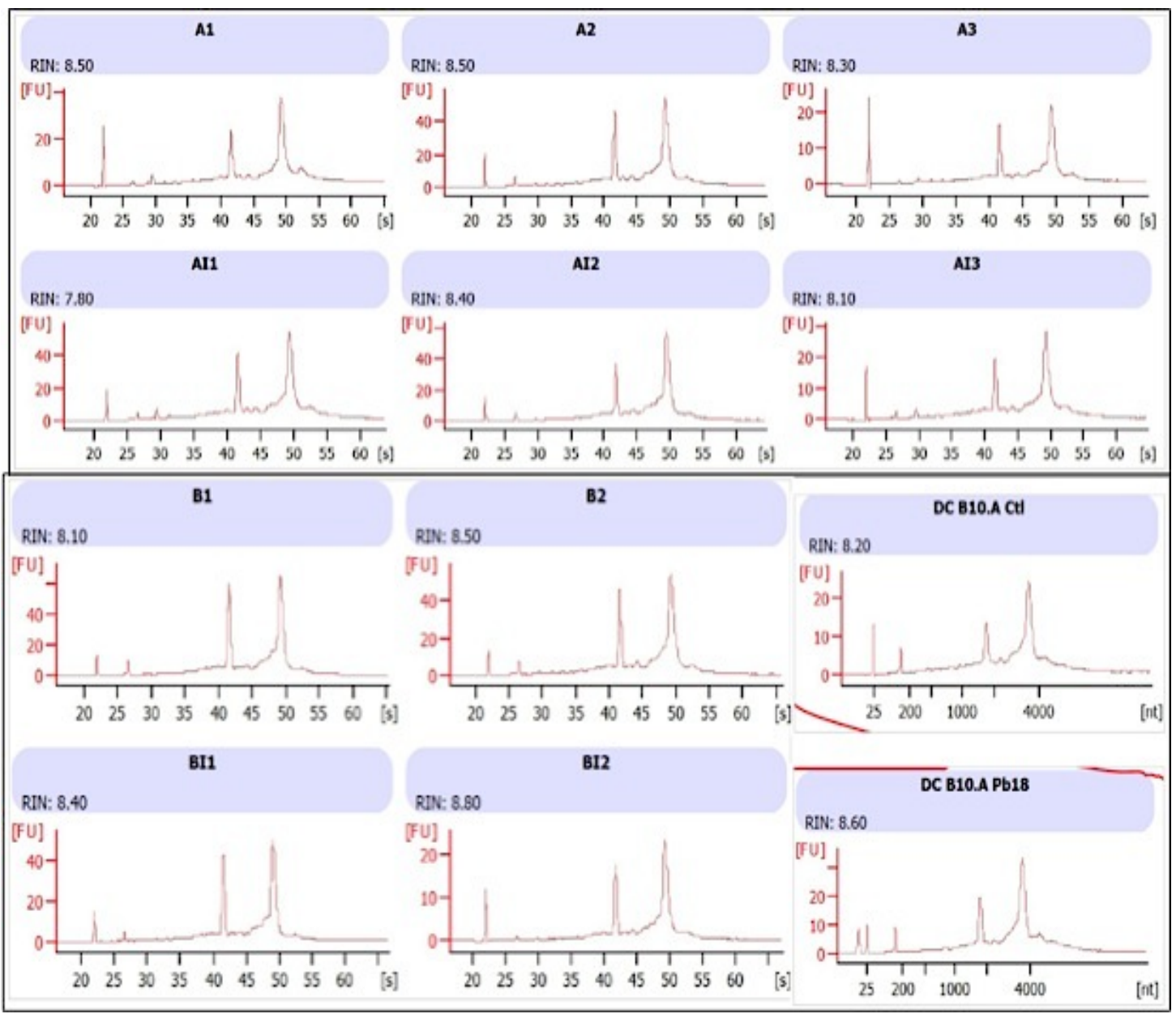

Figura 5.1. Validação da qualidade das amostras de RNA a serem enviadas para o experimento de RNA-seq.

A verificação da qualidade das amostras de RNA foi realizada com o equipamento Bioanalyser. Os valores de RIN (RNA Integrity Number) são indicados para cada amostra. A1-3 e AI1-3: BMDMs de $\mathrm{AJ}$ controle (não infectado) e infectado, respectivamente; B1, 2, DC B10A Ctl e BI1, 2, DC $\mathrm{B} 10 \mathrm{APb} 18$ : BMDMs de B10.A controle (não infectado) e infectado, respectivamente.

$\mathrm{Na}$ Tabela 5.1 é apresentado o número total de reads obtidas para cada amostra de RNAm (RNA poli (A)+) após seu sequenciamento em larga escala (RNAseq) na plataforma HiSeq 2000 Analyser da Illumina (valores superiores a 12 milhões de reads para todas as amostras), e a porcentagem de reads mapeadas no genoma de 
referência de camundongo (mouse build mm10), a qual foi superior a 97\% para todas as amostras analisadas.

Tabela 5.1. Descrição dos principais dados do sequenciamento e "status" das sequências geradas.

\begin{tabular}{|c|c|c|c|c|c|}
\hline Amostras & Reads Total & $\begin{array}{l}\text { Filtragem e } \\
\text { Pareamento }\end{array}$ & $\begin{array}{l}\text { Percentagem } \\
\text { (Filtragem e } \\
\text { Pareamento / } \\
\text { Reads Total) }\end{array}$ & Mapeamento & $\begin{array}{c}\text { Percentagem } \\
\text { (Mapeamento/Filtra- } \\
\text { gem e Pareamento) }\end{array}$ \\
\hline $\mathrm{AJ} 1$ & 20.753 .355 & 15.150 .750 & 73,00 & 14.832 .229 & 97,90 \\
\hline $\mathrm{AJ} 2$ & 21.266 .532 & 15.651 .383 & 73,60 & 15.356 .207 & 98,11 \\
\hline $\mathrm{AJ} 3$ & 15.201 .657 & 10.798 .056 & 71,03 & 10.572 .092 & 97,91 \\
\hline $\mathrm{AJPb} 1$ & 17.801 .444 & 13.189 .133 & 74,09 & 12.951 .214 & 98,20 \\
\hline $\mathrm{AJPb} 2$ & 16.414 .973 & 11.644 .935 & 70,94 & 11.393 .225 & 97,84 \\
\hline $\mathrm{AJPb} 3$ & 20.082 .456 & 14.194 .140 & 70,68 & 13.956 .195 & 98,32 \\
\hline B10A1 & 18.246 .166 & 13.634 .018 & 74,72 & 13.240 .505 & 97,11 \\
\hline B10A2 & 15.721 .166 & 11.458 .063 & 72,88 & 11.231 .965 & 98,03 \\
\hline B10A3 & 14.603 .697 & 10.687 .382 & 73,18 & 10.373 .442 & 97,06 \\
\hline $\mathrm{B} 10 \mathrm{APb} 1$ & 14.737 .027 & 10.303 .973 & 69,92 & 10.032 .907 & 97,37 \\
\hline $\mathrm{B} 10 \mathrm{APb} 2$ & 15.975 .238 & 11.180 .049 & 69,98 & 10.924 .888 & 97,72 \\
\hline $\mathrm{B} 10 \mathrm{APb} 3$ & 12.126 .559 & 8.365 .484 & 68,98 & 8.182 .516 & 97,81 \\
\hline
\end{tabular}

De acordo com o pipeline empregado, como mostrado na figura 4.1 (em metodologia), primeiramente avaliamos as inter-relações entre os perfis de expressão gênica das amostras usando o "edgeR's plotMDS" (plot MDS - "Multidimensional scaling plot" gerado usando o pacote estatístico edgeR). Esta análise emprega a medida da distância de contagens específicas entre as amostras de RNA-seq para gerar um gráfico de escalas multidimensional que mostra as relações entre todos os pares de amostras (Figura 5.2). As distâncias sobre o gráfico representam o coeficiente de variação da expressão entre as amostras para os principais genes que melhor diferenciam as amostras. Para esta análise é empregada a razão dos níveis de expressão normalizada entre as duas condições experimentais $(\operatorname{logFC}-\log$ Fold Change), a fim de avaliar as diferenças entre as amostras. Assim, podemos verificar se as amostras de um mesmo grupo (controle ou infectado) agrupam-se ou não (controle com controle e infectado com infectado). 


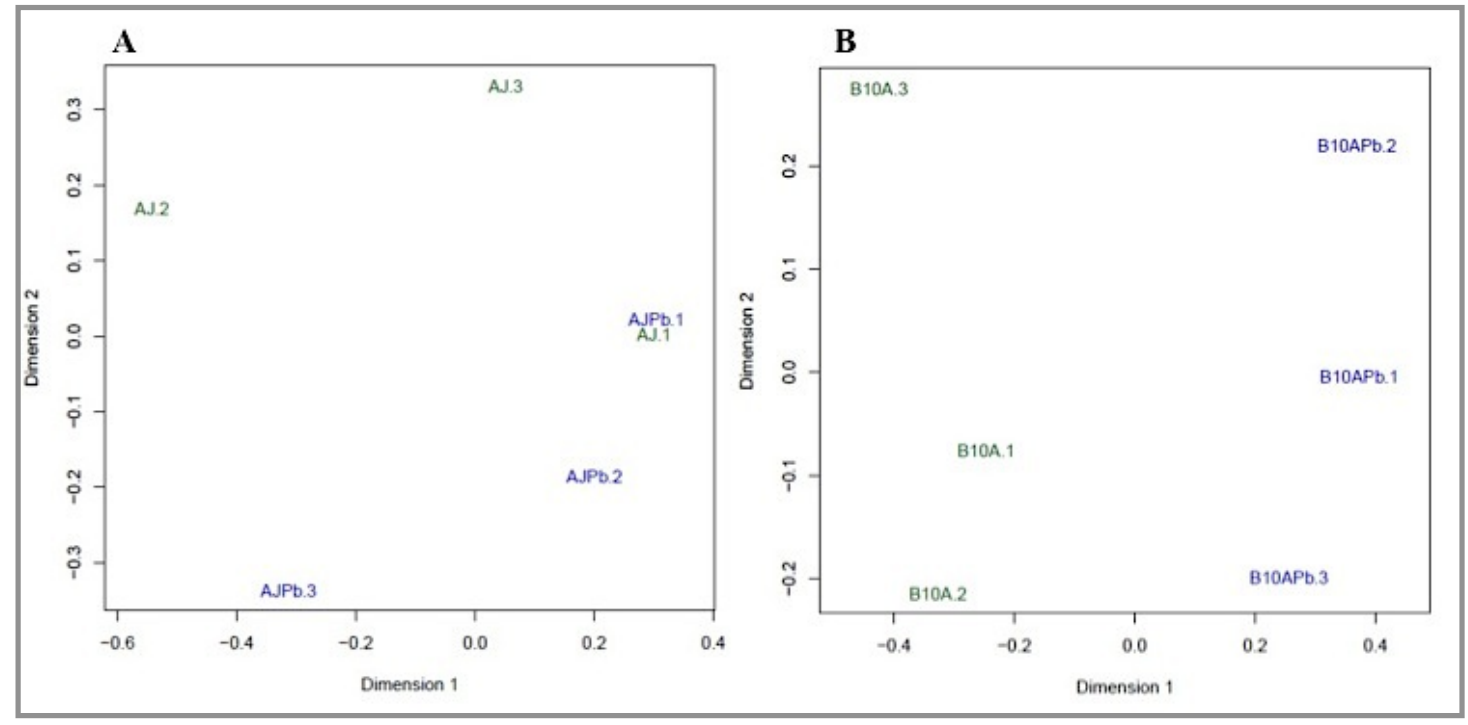

Figura 5.2. Representação da inter-relação entre os perfis de expressão gênica das amostras.

(A) EdgeR's plotMDS dos pares das amostras AJ (BMDCs controle-não infectadas) e $\mathrm{AJPb}$ (BMDCs infectadas com $\mathrm{Pb}$ ). (B) EdgeR's plotMDS dos pares das amostras $\mathrm{B} 10 \mathrm{~A}$ (BMDCs controle-não infectadas) e B10APb (BMDCs infectadas com Pb).

Como pode ser observado na figura 5.2A, um dos pares de amostras do modelo $\mathrm{AJ} / \mathrm{AJPb}$ (control/infectado) não se diferenciou no plotMDS (replicata biológica 1), e portanto foi retirado das analises comparativas posteriores. O restante das análises para linhagem murina $\mathrm{A} / \mathrm{J}$ foi então conduzido apenas com as duplicatas biológicas (pares, controle e infectado, das replicatas biológicas 2 e 3). Para as amostras do modelo $\mathrm{B} 10 \mathrm{~A} / \mathrm{B} 10 \mathrm{APb}$, as análises seguiram-se com os dados das triplicatas biológicas.

Em seguida, com os parâmetros de cortes de FDR (p-valor corrigido para múltiplas hipóteses utilizando o método Benjamini-Hochberg que tem como objetivo reduzir False Discovery Rate, ou falso positivos) $<0,05$ e MagnFC $>1,4$ para a determinação de genes diferencialmente expressos no nosso modelo de estudo, foram gerados dados para os grupos diferentes experimentais em estudo (BMDCs controle $\mathrm{X}$ BMDCs infectadas com $P$. brasiliensis de ambas as linhagens de camundongo utilizadas). Os resultados obtidos são representados pelo edgeR's plotSmear na figura 5.3 , onde cada ponto representa um gene analisado. 


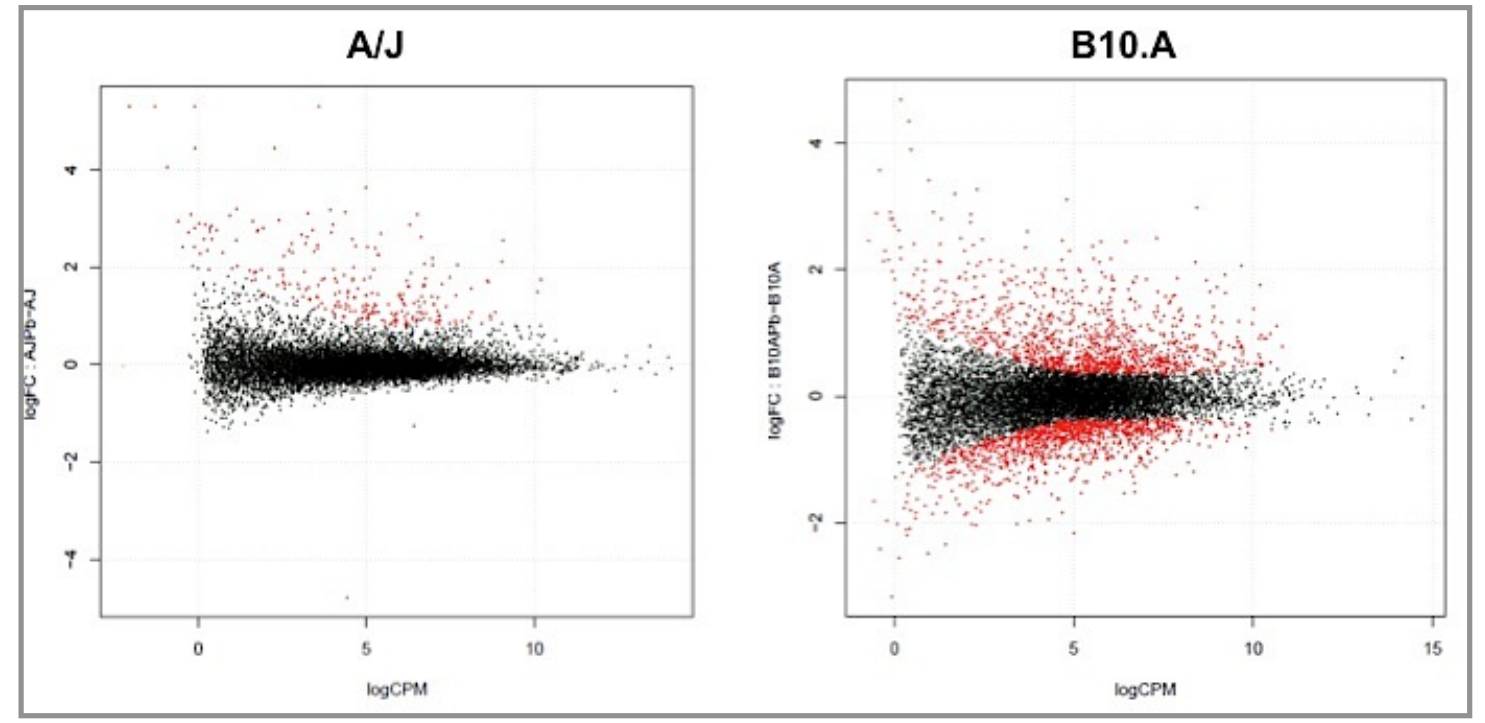

Figura 5.3. Representação gráfica dos genes diferencialmente expressos no modelo de infecção de BMDCs com $P$. brasiliensis para as linhagens de camundongo $A / J$ e B10.A, segundo os parâmetros de FDR $<0,05$ e MagnFC > 1,4.

O EdgeR's plotSmear relaciona o log fold change (o log da razão dos níveis de expressão normalizada entre as duas condições experimentais) versus o log de contagens por milhão (CPM).

Desta figura, obtemos um panorama geral da quantidade de genes diferencialmente expressos em cada modelo analisado, representados pelos pontos em vermelho seriam os genes que passaram ambos critérios supracitados (pontos acima de zero no eixo Y para os genes regulados positivamente, e abaixo para os genes regulados negativamente). A linhagem murina resistente (Figura 5.3A). apresentou uma menor variação de expressão diferencial de genes, tanto induzidos como reprimidos, que a linhagem susceptível (Figura 5.3B). Por outro lado, a linhagem A/J além de apresentar menor número de genes significativamente diferencialmente expresso, a maioria desse estavam induzidos em relação com o controle (Figura 5.3A). A seguir, estes dados são representados por um diagrama de Venn e um heatmap com a amostragem de genes em cada um dos modelos de estudo (figura 5.4). 

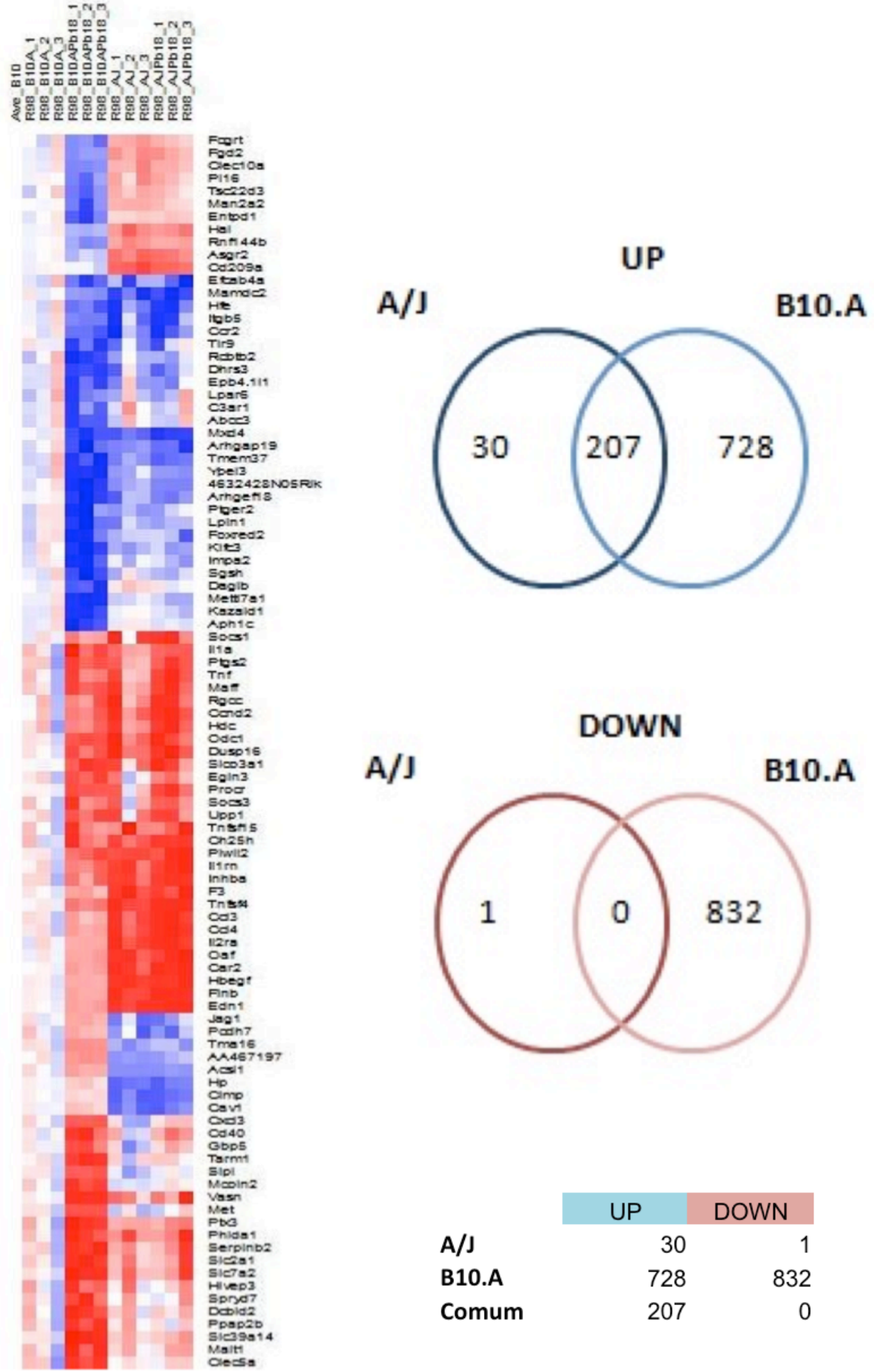

Figura 5.4. Representação quantitativa e visual do comportamento dos genes diferencialmente modulados em BMDCs de camundongos A/J e B10.A após infeç̧ão com $P$. brasiliensis.

(A) O heatmap foi gerado com genes de ambas as linhagens de camundongos, A/J e B10.A, em ambas as condições experimentais, controle e infectado com Pb18, via programa dChip (www.dChip.org). A cor vermelho indica aumento e a azul indica a diminuição da expressão relativa à média do log CPM (contagens normalizadas) para todas as amostras. (B) Diagrama de Venn resumindo os resultados dos genes diferencialmente expressos entre as células dendríticas controle e infectadas com $\mathrm{Pb} 18$ das linhagens de camundongos A/J e B10.A . 
A observação das diferenças de indução (vermelho) e repressão (azul), representadas no heatmap (figura 5.4A), sinalizam que houve uma expressão diferencial dos genes selecionados de ambas as linhagens de camundongos, A/J e B10.A, e em ambas condições experimentais, controle e infectado com Pb18. A igual que como a figura 5.3, observamos uma grande diferença entre o controle e infectado para linhagem B10.A, mas não tanto no $\mathrm{A} / \mathrm{J}$ (figura 5.4A). Isto dá a impressão de que a linhagem susceptível, após 6 horas de infecção, apresenta uma ativação geral e "intensa/exacerbada" da transcrição de vários genes, quanto como o resistente quase não ha diferencia entre o infectado e o não infectado (figura 5.4A). O que poderia indicar uma ativação mais lenta ou controlada da transcrição frente a infecção no camundongo resistente. Entre as linhagem, também, podemos observar grupos de genes diferencialmente expressos (reprimidos em uma linhagem e induzido na outra) que será analisado nas próximas etapas para determinar sua importância no infecção com P. brasiliensis. Em resumo, do total dos genes diferencialmente expressos, 207 genes foram comumente induzidos, por $\mathrm{A} / \mathrm{J}$ e B10.A, enquanto os reprimidos não tiveram nem um gene diferencialmente expresso em comum (figura 5.4B).

\subsubsection{Alguns Dados de Expressão Diferencial dos resultados do RNA-seq}

Foi feito um analise preliminar dos genes diferencialmente expressos, induzidos e reprimidos, em BMDCs de ambas as linhagens de camundongos quando infectado com $\mathrm{Pb} 18$ de forma a ter uma ideia de tipo/categoria de genes estava sendo modulados. Análises mais profundas serão feitas nas vias e nos genes de interesse para escrita do artigo após os ajustamentos no pipeline terminarem e o melhor método para o análise comparativo for definido. A análise das categorias dos genes induzidos/reprimidos na interação entre BMDCs, tanto de A/J como de B10.A, e Pb18 foi feito conforme a sua ontologia genica $(\mathrm{GO})$ e seu interação/participação em vias de processos biológicos conhecidos (KEGG - Kyoto Encyclopedia of Genes and Genomes) pelo software DAVID Bioinformatics Resources 6.7 (Huang et al. 2009).

A categorização por GO é utilizado para descrever a representação de genes e produtos génicos em termos de seus processos biológicos associados, componentes celulares e funções moleculares de maneira independente de espécies. É importante 
ressaltar que o mesmo gene por pertencer a varias categorias funcionais. Em ambas linhagens mostrou um enriquecimento (agrupações estaticamente sobre-representada) em genes relacionados a resposta imune e sua regulação, tanto na produção de citocinas como na ativação celular, entre outros agrupamentos funcionais tabelados a seguir (Tabela 5.2 à 5.6).

Tabela 5.2. Categorização dos principais genes induzidos da biblioteca de BMDC da linhagem de camundongo A/J infectado com Pb18. Conforme seu GO (gene ontology) e distribuídos segundo a função no hospedeiro (categoria: GOterm BP FAT, $\mathbf{p}<\mathbf{0 , 0 5}$ ). Em itálico as vias em comum com B10.A (Tabela 5.3). A coluna \% representa a porcentagem na categoria do total dos genes induzidos. A ultima coluna é o p-valor corrigido para múltiplas hipóteses utilizando o método Benjamini-Hochberg.

\begin{tabular}{|l|c|c|c|c|}
\hline Termos GO & $\begin{array}{c}\# \\
\text { Genes }\end{array}$ & $\mathbf{\%}$ & $\begin{array}{c}\text { GO } \\
\text { Accession }\end{array}$ & $\begin{array}{c}\text { P } \\
\text { (Benjamini) }\end{array}$ \\
\hline Immune response & 57 & 2,7 & GO:0006955 & $4,9 \times 10^{-37}$ \\
\hline Defense response & 33 & 1,5 & GO:0006952 & $3,9 \times 10^{-13}$ \\
\hline Inflammatory response & 20 & 0,9 & GO:0006954 & $2,0 \times 10^{-8}$ \\
\hline Response to wounding & 23 & 1,1 & GO:0009611 & $1,1 \times 10^{-7}$ \\
\hline Response to virus & 12 & 0,6 & GO:0009615 & $6,010^{-7}$ \\
\hline Regulation of cytokine production & 13 & 0,6 & GO:0001817 & $3,510^{-5}$ \\
\hline Regulation of apoptosis & 24 & 1,1 & GO:0042981 & $6,5 \times 10^{-5}$ \\
\hline Regulation of programmed cell death & 24 & 1,1 & GO:0043067 & $7,1 \times 10^{-5}$ \\
\hline Regulation of cell death & 24 & 1,1 & GO:0010941 & $7,0 \times 10^{-5}$ \\
\hline Regulation of cell proliferation & 23 & 1,1 & GO:0042127 & $1,1 \times 10^{-4}$ \\
\hline Positive regulation of cytokine production & 9 & 0,4 & GO:0001819 & $1,1 \times 10^{-4}$ \\
\hline Chemotaxis & 11 & 0,5 & GO:0006935 & $1,1 \times 10^{-4}$ \\
\hline Taxis & 11 & 0,5 & GO:0042330 & $1,1 \times 10^{-4}$ \\
\hline ISG15-protein conjugation & 4 & 0,2 & GO:0032020 & $8,0 \times 10^{-4}$ \\
\hline Apoptosis & 19 & 0,9 & GO:0006915 & $1,8 \times 10^{-3}$ \\
\hline
\end{tabular}

Tabela 5.3. Categorização dos principais genes induzidos da biblioteca de BMDC da linhagem de camundongo B10.A infectado com Pb18. Conforme seu GO (gene ontology) e distribuídos segundo a função no hospedeiro (categoria: goterm BP FAT, p<0,05). Em itálico as vias em comum com A/J (Tabela 5.2). A coluna \% representa a porcentagem na categoria do total dos genes induzidos. A ultima coluna é o p-valor corrigido para múltiplas hipóteses utilizando o método Benjamini-Hochberg.

\begin{tabular}{|l|c|c|c|c|}
\hline Termos GO & $\begin{array}{c}\# \\
\text { Genes }\end{array}$ & $\mathbf{\%}$ & $\begin{array}{c}\text { GO } \\
\text { Accession }\end{array}$ & $\begin{array}{c}\text { P } \\
\text { (Benjamini) }\end{array}$ \\
\hline Immune response & 94 & 1,1 & GO:0006955 & $2,6 \times 10^{-30}$ \\
\hline Regulation of cytokine production & 35 & 0,4 & GO:0001817 & $1,1 \times 10^{-12}$ \\
\hline Response to wounding & 54 & 0,6 & GO:0009611 & $1,8 \times 10^{-11}$ \\
\hline Defense response & 62 & 0,7 & GO:0006952 & $2,8 \times 10^{-11}$ \\
\hline Inflammatory response & 40 & 0,5 & GO:0006954 & $6,0 \times 10^{-10}$ \\
\hline Regulation of cell activation & 32 & 0,4 & GO:0050865 & $2,8 \times 10^{-9}$ \\
\hline Regulation of leukocyte activation & 31 & 0,4 & GO:0002694 & $9,0 \times 10^{-9}$ \\
\hline Regulation of apoptosis & 63 & 0,8 & GO:0042981 & $4,5 \times 10^{-8}$ \\
\hline Regulation of programmed cell death & 63 & 0,8 & GO:0043067 & $6,7 \times 10^{-8}$ \\
\hline Regulation of cell death & 63 & 0,8 & GO:0010941 & $7,5 \times 10^{-8}$ \\
\hline Negative regulation of molecular function & 27 & 0,3 & GO:0044092 & $9,7 \times 10^{-8}$ \\
\hline Regulation of lymphocyte activation & 28 & 0,3 & GO:0051249 & $1,3 \times 10^{-7}$ \\
\hline Regulation of cell proliferation & 60 & 0,7 & GO:0042127 & $1,9 \times 10^{-7}$ \\
\hline Positive regulation of cytokine production & 18 & 0,2 & GO:0001819 & $4,3 \times 10^{-7}$ \\
\hline Apoptosis & 52 & 0,6 & GO:0006915 & $2,4 \times 10^{-6}$ \\
\hline
\end{tabular}


Os primeiros 15 grupos funcional (ontológia) de genes induzidos em BMDCS após 6h da infecção com Pb18 com número agrupamento de genes estatisticamente sobre-expressados e com o p-value ajustado pelo método de Benjamini-Hochberg menor que 005) encontra-se descrito na tabela 5.2 para a linhagem de A/J e na tabela 5.3 para a linhagem B10.A. Ambas linhagens agruparam genes em categorias comuns, como é de espera dado que ambos enfrenta o mesmo estimulo, a diferença principal sendo o numero e qual genes encontra-se induzidos em cada categoria. Análises in silico será feito, após do ajustamento do pipeline, para determinar o efeito dessa diferencia em diferente vias de interesse esta sendo realizada para o artigo em produção.

Vários agrupamentos apresenta termos similares, como resposta imune, reposta de defesa, resposta inflamatória e resposta à ferida todos relacionados ao processo de defesa de uma quebra do equilíbrio homeostático, nesse caso devido a resposta à infecção, e provavelmente vários genes forma parte de diferente categorias GO ao mesmo tempo. Indiferentemente, todas categorias se catalogam com a calibração/adaptação do organismo a uma potencial ameaça interna (lesão por agentes físicos ou químicos) ou invasiva (corpo estranho ou infecção) que desencadeia diferentes reações, e resulta na restrição de danos para o organismo atacados ou prevenção/recuperação da infecção causada pelo ataque do patógeno. No caso da resposta inflamatória, por exemplo, o processo é caracterizado por vasodilatação local, extravasamento de plasma em espaços intercelulares e acúmulo de leucócitos e macrófagos. No entanto, as resposta de defesa e a resposta à ferida é caracterizado pelos mesmos processos com focos ligeiramente diferentes.

Adicionalmente, ambos linhagens murinas induziram genes relacionados com a modulação na frequência, taxa ou extensão na produção de citocinas, e ligados ao aumento dessa produção. De igual forma, ambos também induziram genes estão ligados à morte celular, em especial a morte celular programada, e sua regulação.

Exclusivamente na linhagem A/J (resistente) foram agrupados genes ligados ao direcionamento celular, provavelmente ligado ao recrutamento de células ao lugar da infecção (tabela 5.2). Se destaca nesses genes relacionados ao ISG15, que além do recrutamento de neutrófilos, induzem a proliferação de células NK e a produção de INF- $\gamma$ (http://www.uniprot.org/uniprot/Q64339). Sendo assim, em conjunto com os agrupamentos e o numero de genes induzidos, indicaria que o A/J monta uma resposta 
dirigida e controlada. No entanto, mais estudos deverão ser executados para entender o mecanismo.

No B10.A (susceptível) forma agrupados, exclusivamente, os genes relacionado a "regulação negativa da função molecular" e a "regulação da ativação de leucócitos" (tabela 5.3). O efeito desses agrupamentos na montagem da defesa vai depender de quais funções de atividade biológica estão sendo inibidas ou induzidas. Similar ao A/J, os agrupamentos induzidos, com exceção a "regulação negativa da função molecular", indicaria que o B10.A monta uma resposta dirigida. No enquanto o numero de genes induzidos em cada categoria poderia indicar que a resposta é exacerbada. Igualmente, mais estudos deverão ser realizados para compreender o estado de suscetibilidade.

Em relação aos genes reprimidos, é importante mencionar para a linhagem A/J que o nosso pipeline só identificou um gene reprimido Gm15710, pseudogene similar à proteína ribosomal L13. Enquanto a linhagem B10.A, os genes reprimidos não foram agrupados de forma significativa em relação a categorias $\mathrm{GO}(\mathrm{p}>0,05)$

A representação das vias metabólicas do hospedeiro frente à infecção foram obtidas do banco de dados KEGG (Kyoto Encyclopedia of Genes and Genomes), e, igual com a categorização por GO, um mesmo gene pode pertencer a diferentes vias. A análise por essa metodologia evidenciou, em termos gerais, em ambas linhagens, uma montagem para uma reposta imune: Cytokine-cytokine receptor interaction, Chemokine signaling pathway, RIG-I-like receptor signaling pathway, Toll-like receptor signaling pathway, NOD-like receptor signaling pathway, Cytosolic DNAsensing pathway e algumas de suas cascadas de sinalização MAPK signaling pathway e Jak-STAT signaling pathway (Tabela 5.4 e 5.5). Sendo, assim, de forma geral, a diferença entre a linhagem resistência e susceptível a PCM o numero de genes associado a cada via induzido, e talvez o grau a indução e seu papel na via.

No entanto, ambas linhagens murinas apresentou, também, vias relacionadas como diabetes mellitus tipo I, rejeição ao aloenxerto e enxerto no hospedeiro versus tecido doado, que pareceria, sem considerar cada gene da via, nada relacionado com uma resposta contra P. brasiliensis (Tabela 5.4 e 5.5). Porem, quando analisamos os genes agrupados nessas vias tem a ver com resposta pro-inflamatória. Por exemplo, TNF- $\alpha$, IL $1 \alpha / \beta$ e IL6 estão induzidos nessas vias, além do seu efeito pro-inflamatório, 
encontra-se associado radicais livres de oxigênio e nitrogênio e também faz parte da via de doenças prionicas. Outros exemplos de genes pertencentes a essas vias que se encontra induzidos em ambas linhagens são o gene para a molécula co-estimuladora de células T CD-40, o gene para o complexo principal de histocompatibilidade I (Major Histocompatibility Complex I - MHC I), os genes das interleucinas IL2, IL10 2 e IL12, e o gene do interferon alfa (INF- $\alpha$ ). O que demostra o sobre-lapso das vias. E igual as vias sabidamente relacionados com a resposta imune, a diferencia na resistência/susceptibilidade parece esta associada ao numero de genes induzidos, o grau de indução e sua função na via.

Por outro, observamos as vias enriquecidas de KEGG exclusivas a partir dos genes induzidos em BMDCS de B10.A depois 6h de infecção com Pb18, como antigen processing and presentation e Adipocytokine signaling pathway, importantes no processo imunológico e no metabolismo energético, respetivamente (Tabela 5.5). Como vias que pareceria não relacionada com PCM como a câncer e doenças príonicas que como supracitado também contem genes relacionados a outras vias (Tabela 5.5). Análises in silico será feito, após do ajustamento do pipeline, para difícil de estabelecer como estas funções metabólicas se relacionam com a suscetibilidade à infecção para o artigo em produção.

Tabela 5.4. Vias de KEGG super-representadas para genes induzidos em BMDC da linhagem de camundongo A/J infectado com Pb18 $(\mathbf{p}<\mathbf{0 , 0 5})$. Em itálico as vias em comum com B10.A (Tabela 5.5). A coluna \% representa a porcentagem na categoria do total dos genes induzidos. A ultima coluna é o p-valor corrigido para múltiplas hipóteses utilizando o método Benjamini-Hochberg.

\begin{tabular}{|l|c|c|c|c|}
\hline Vias & \# Genes & $\mathbf{\%}$ & p-value & Benjamini \\
\hline Cytokine-cytokine receptor interaction & 25 & 1,2 & $5,3 \times 10^{-13}$ & $4,8 \times 10^{-11}$ \\
\hline Jak-STAT signaling pathway & 15 & 0,7 & $1,5 \times 10^{-7}$ & $3,4 \times 10^{-6}$ \\
\hline Chemokine signaling pathway & 15 & 0,7 & $1,4 \times 10^{-6}$ & $2,5 \times 10^{-5}$ \\
\hline Cytosolic DNA-sensing pathway & 12 & 0,6 & $9,3 \times 10^{-10}$ & $4,3 \times 10^{-8}$ \\
\hline RIG-I-like receptor signaling pathway & 12 & 0,6 & $1,0 \times 10^{-8}$ & $3,0 \times 10^{-7}$ \\
\hline MAPK signaling pathway & 12 & 0,6 & $4,1 \times 10^{-3}$ & $3,3 \times 10^{-2}$ \\
\hline Toll-like receptor signaling pathway & 11 & 0,5 & $4,4 \times 10^{-6}$ & $6,7 \times 10^{-5}$ \\
\hline NOD-like receptor signaling pathway & 9 & 0,4 & $6,8 \times 10^{-6}$ & $8,8 \times 10^{-5}$ \\
\hline Allograft rejection & 7 & 0,3 & $3,6 \times 10^{-4}$ & $4,0 \times 10^{-3}$ \\
\hline Graft-versus-host disease & 7 & 0,3 & $3,6 \times 10^{-4}$ & $4,0 \times 10^{-3}$ \\
\hline Type I diabetes mellitus & 7 & 0,3 & $5,6 \times 10^{-4}$ & $5,6 \times 10^{-3}$ \\
\hline
\end{tabular}


Tabela 5.5. Vias de KEGG enriquecidas para genes induzidos em BMDC da linhagem de camundongo B10.A infectado com Pb18 $(\mathbf{p}<\mathbf{0 , 0 5})$. Em itálico as vias em comum com A/J (Tabela 5.4). A coluna \% representa a porcentagem na categoria do total dos genes induzidos. A ultima coluna é o p-valor corrigido para múltiplas hipóteses utilizando o método Benjamini-Hochberg.

\begin{tabular}{|l|c|c|c|c|}
\hline Vias & \# Genes & $\mathbf{\%}$ & p-value & Benjamini \\
\hline Cytokine-cytokine receptor interaction & 43 & 0,5 & $3,3 \times 10^{-11}$ & $5,1 \times 10^{-9}$ \\
\hline NOD-like receptor signaling pathway & 18 & 0,2 & $2,9 \times 10^{-8}$ & $2,2 \times 10^{-6}$ \\
\hline Jak-STAT signaling pathway & 28 & 0,3 & $6,9 \times 10^{-8}$ & $3,6 \times 10^{-6}$ \\
\hline Toll-like receptor signaling pathway & 22 & 0,3 & $9,2 \times 10^{-8}$ & $3,5 \times 10^{-6}$ \\
\hline MAPK signaling pathway & 36 & 0,4 & $1,5 \times 10^{-6}$ & $4,8 \times 10^{-5}$ \\
\hline Chemokine signaling pathway & 25 & 0,3 & $7,6 \times 10^{-5}$ & $2,0 \times 10^{-3}$ \\
\hline Type I diabetes mellitus & 13 & 0,2 & $1,7 \times 10^{-4}$ & $3,7 \times 10^{-3}$ \\
\hline Cytosolic DNA-sensing pathway & 12 & 0,1 & $2,0 \times 10^{-4}$ & $3,9 \times 10^{-3}$ \\
\hline Apoptosis & 15 & 0,2 & $3,2 \times 10^{-4}$ & $5,5 \times 10^{-3}$ \\
\hline Allograft rejection & 12 & 0,1 & $3,3 \times 10^{-4}$ & $5,0 \times 10^{-3}$ \\
\hline Graft-versus-host disease & 12 & 0,1 & $3,3 \times 10^{-4}$ & $5,0 \times 10^{-3}$ \\
\hline RIG-I-like receptor signaling pathway & 13 & 0,2 & $3,6 \times 10^{-4}$ & $5,0 \times 10^{-3}$ \\
\hline Pathways in cancer & 32 & 0,4 & $2,3 \times 10^{-3}$ & $2,9 \times 10^{-2}$ \\
\hline Prion diseases & 8 & 0,1 & $2,9 \times 10^{-3}$ & $3,4 \times 10^{-2}$ \\
\hline Adipocytokine signaling pathway & 11 & 0,1 & $4,0 \times 10^{-3}$ & $4,3 \times 10^{-2}$ \\
\hline Antigen processing and presentation & 13 & 0,2 & $4,8 \times 10^{-3}$ & $4,8 \times 10^{-2}$ \\
\hline
\end{tabular}

Em contrapartida, somente três vias enriquecidas de KEGG são significativamente reprimidas $(\mathrm{p}<0,05)$ na BMDCs linhagem B10.A infectadas com Pb18: a do lisossoma, a da sinalização de receptores ativados por proliferador de peroxissoma (Peroxisome proliferator-activated receptors - PPAR) e a da degradação dos aminoácidos valina, leucina e isoleucina (Tabela 5.6). A repressão de elementos da via do lisossoma associados com acidificação do lisossomal (ATPeV), a hidrolases acidas lisosomal (proteases, glicosidases, sulfatases, lipases, fosfatases e esfingomielinase) e algumas proteínas da membrana lisososmal menores. O que poderia dificultar o processamento de antígeno e, por conseguinte, sua apresentação, apesar de genes relacionados apresentarem expressão aumentada (Tabela 5.5). Anteriormente foi demonstrado por Ferreira et al. (2007) que DCs de camundongos sensíveis (B10.A) além de ter índice fagocitário maior em comparação com camundongos resistentes, as leveduras fagocitados permaneciam viáveis. Isso pode ser devido ao mal funcionamento do lisossomo devido a repressão da transcrição de seus genes e provalmente de suas proteínas. A via de sinalização de PPAR está ligada à fatores de transcrição ativados por lipídeos e participam na homeostase de lipídeos e na regulação da resposta inflamatória (Lemberger et al. 1996, Daynes e Jones 2002). Além do gene PPAR $\gamma$, previamente demostrado sua importância no controle candidíases (Coste et al. 2003, Galès et al. 2010, Lefevre et al. 2010) esta reprimido, 
outros genes relacionado ao metabolismo de lipídios (transporte e oxidação de ácidos grassos e metabolismo de colesterol), diferenciação de adipócitos e gluconeogêneses também encontra-se reprimido. Já a inibição generalizada dos genes relacionados com a degradação de valina, leucina e isoleucina poderia permitir o aumento da matéria prima para a produção de proteínas de diferentes vias ou bloqueia a biossíntese de outras proteínas ao desviar recursos para esta via. O significado da repressão dessas vias na suscetibilidade da linhagem B10.A será analisado, após do ajustamento do pipeline, para o artigo em produção.

Tabela 5.6. Vias de KEGG enriquecidas para genes reprimidos em BMDC da linhagem de camundongo B10.A infectado com Pb18 $(\mathbf{p}<\mathbf{0 , 0 5})$. A coluna $\%$ representa a porcentagem na categoria do total dos genes induzidos. A ultima coluna é o p-valor corrigido para múltiplas hipóteses utilizando o método Benjamini-Hochberg.

\begin{tabular}{|l|c|c|c|c|}
\hline Vias & \# Genes & \% & p-value & Benjamini \\
\hline Lysosome & 17 & 0,2 & $3,5 \times 10^{-5}$ & $5,6 \times 10^{-3}$ \\
\hline PPAR signaling pathway & 12 & 0,1 & $4,4 \times 10^{-4}$ & $3,5 \times 10^{-2}$ \\
\hline $\begin{array}{l}\text { Valine, leucine and isoleucine } \\
\text { degradation }\end{array}$ & 9 & 0,1 & $5,9 \times 10^{-4}$ & $3,1 \times 10^{-2}$ \\
\hline
\end{tabular}

\subsubsection{Validação dos dados de RNAseq}

Com o objetivo de validar os resultados obtidos por sequenciamento em larga escala foram escolhidos genes sabidamente relacionados à resposta imune inata antifúngica. Os genes escolhidos para este analises foram as citocinas TNF- $\alpha$, IL1 $\beta$, IL6 e IL10, as quimiocinas CCL22 e CXCL10, o adaptador molecular MyD88, e o fator de transcrição NF- $\kappa$ B. Os níveis destes transcritos provenientes das células dendríticas de camundongos das linhagem A/J (resistente) e B10.A (suscetível), tanto na condição controle como infectado, foram avaliados por qRT-PCR e os padrões expressão dos resultados foram comparados aqueles adquiridos pelo método de RNAseq (Figura 5.5). 
A $/ \mathbf{J}$

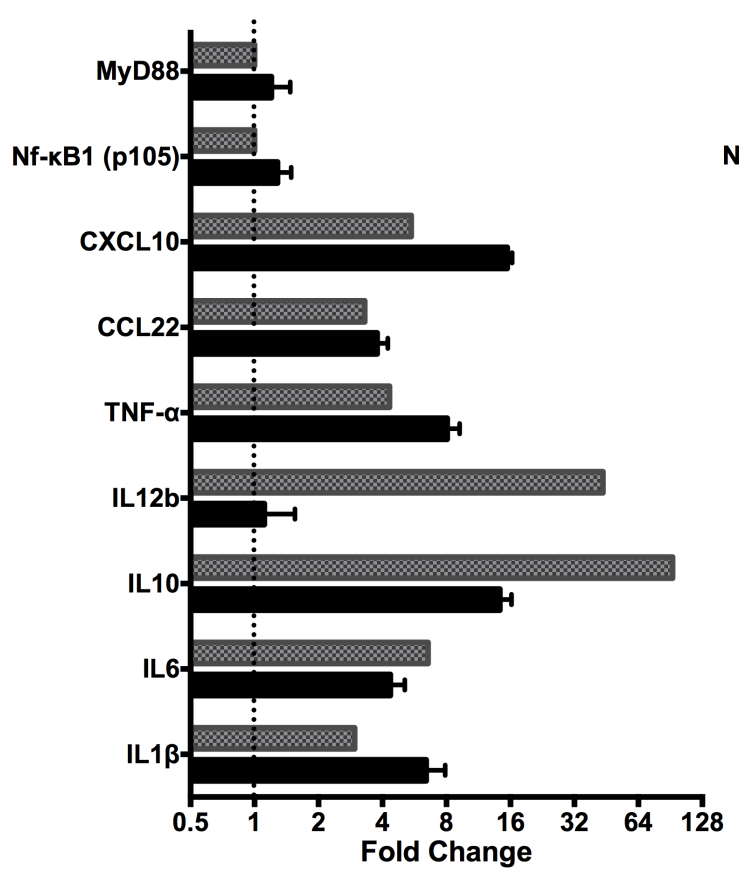

B10.A

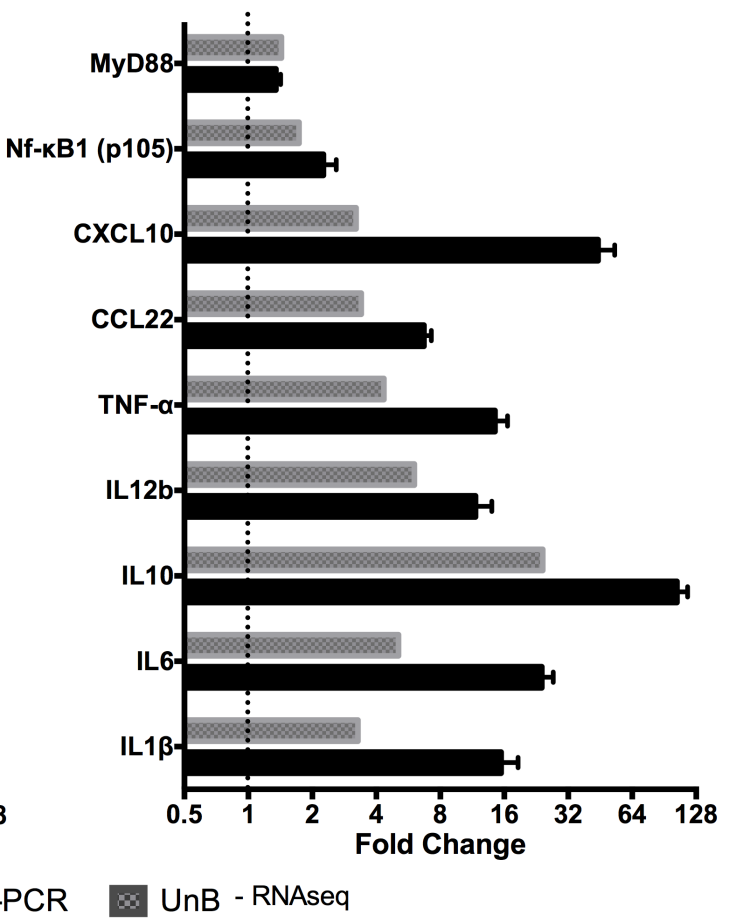

Figura 5.5. Comparação dos padrões de expressão dos resultados obtidos pelas metodologias de qRT-PCR e RNA-seq para os níveis de transcritos de genes relacionados à resposta imune de BMDCs das linhagens de camundongos resistente (A/J) e susceptíveis (B10.A) após infecção por $P$. brasiliensis.

Os genes analisados codificam citocinas (IL1 $\beta$, IL6, IL10 e TNF- $\alpha$ ), quimiocinas (CCL22 e CXCL10), o fator de transcrição NF-kB1 (p105) e a molécula adaptadora MyD88. O fold change foi calculado pelo método $2^{-\Delta \Delta C \mathrm{t}}$ para os resultados de qRT-PCR e pelo programa edgeR para os resultados de RNAseq.

Todos os transcritos dos genes selecionados, com exceção da IL12b no modelo $\mathrm{A} / \mathrm{J}$, apresentaram padrão de acúmulo de transcrito similar, induzidos ou não modulados, quando seus níveis foram quantificados pelas metodologias de RNAseq e qRT-PCR (Figura 5.5). Esses dados validam os resultados obtidos pela metodologia de RNAseq.

Uma maior aprofundamento dos resultados do RNA-seq estão em andamento, a fim de obter uma melhor compreensão em nível molecular do perfil comparativo da resposta imunológica inicial à infecção $P$. brasiliensis, entre hospedeiros resistentes e suscetíveis, em células dendríticas. Estes resultados serão concluídos para publicação do artigo científico referente a esta parte do trabalho. 
Devido a importância dos genes selecionados para a validação do RNAseq na resposta imune inata, é interessante observar as diferenças no acúmulo de seus transcritos nas células dendríticas (BMDCs) de camundongos das linhagem A/J (resistente) e B10.A (suscetível) frente à infecção por P. brasiliensis (Figura 5.6). Observou-se que as BMDCs, tanto das linhagens A/J como B10.A de camundongos, apresentam um aumento significativo no acúmulo dos transcritos das citocinas (IL1 $\beta$, IL6, IL10 e TNF- $\alpha$ ) e quimiocinas (CCL-22 e CXCL-10) avaliadas quando da

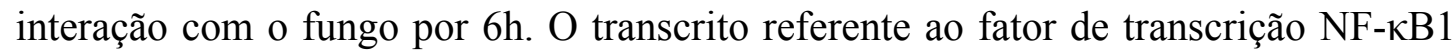
também tem seus níveis aumentados após a infecção; porém esse aumento é significativo apenas em BMDCs derivadas da linhagem murina suscetível à PCM (B10.A). Este resultado é similar ao obtido por Tavares et al. (2012) em um estudo com BMDCs de camundongos da linhagem BALB/c, hospedeiro com resistência intermediária ao P. brasiliensis, em que os genes das citocinas IL-12 e TNF- $\alpha$, assim

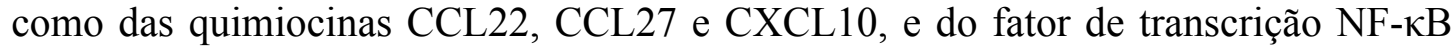
tiveram sua expressão significativamente aumentada.

No entanto, no presente estudo, os níveis de transcritos da molécula adaptadora MyD88 nas BMDCs co-cultivadas por 6h com $P$. brasiliensis não mostraram nenhuma mudança significativa em qualquer uma das linhagens murinas analisadas. O papel de MyD88 na infecção por P. brasiliensis permanece incerto e trabalhos na literatura são conflitantes quanto à sua importância na resistência do hospedeiro mamífero à PCM. Em um trabalho realizado por González et al. (2008), utilizando camundongos nocaute para o gene MyD88 infectados com o fungo $P$. brasiliensis, constatou-se que a resposta do hospedeiro à levedura é independente da presença desta molécula adaptadora (González et al. 2008). Por outro lado, outro trabalho, também usando camundongos nocautes, demonstrou que MyD88 é indispensável para uma resposta efetiva ao P. brasiliensis (Loures et al. 2011). Ambos os trabalhos utilizaram a mesma linhagem de camundongo (MyD88-/- C57BL/6), mesma via de infecção (intratraqueal) e mesma quantidade de inóculo $\left(10^{6}\right)$. As únicas diferenças experimentais foram o tempo de análise e os gêneros dos animais: de 7 e 14 dias após infecção em machos (González et al. 2008) e 48h e 8 semanas após infecção em animais de ambos os gêneros (Loures et al. 2011). Isso sugere que mesmo em condições experimentais muito similares, parâmetros tais como gênero do animal e o tempo após a exposição ao fungo podem ser importantes no direcionamento da resposta montada pelo hospedeiro. 

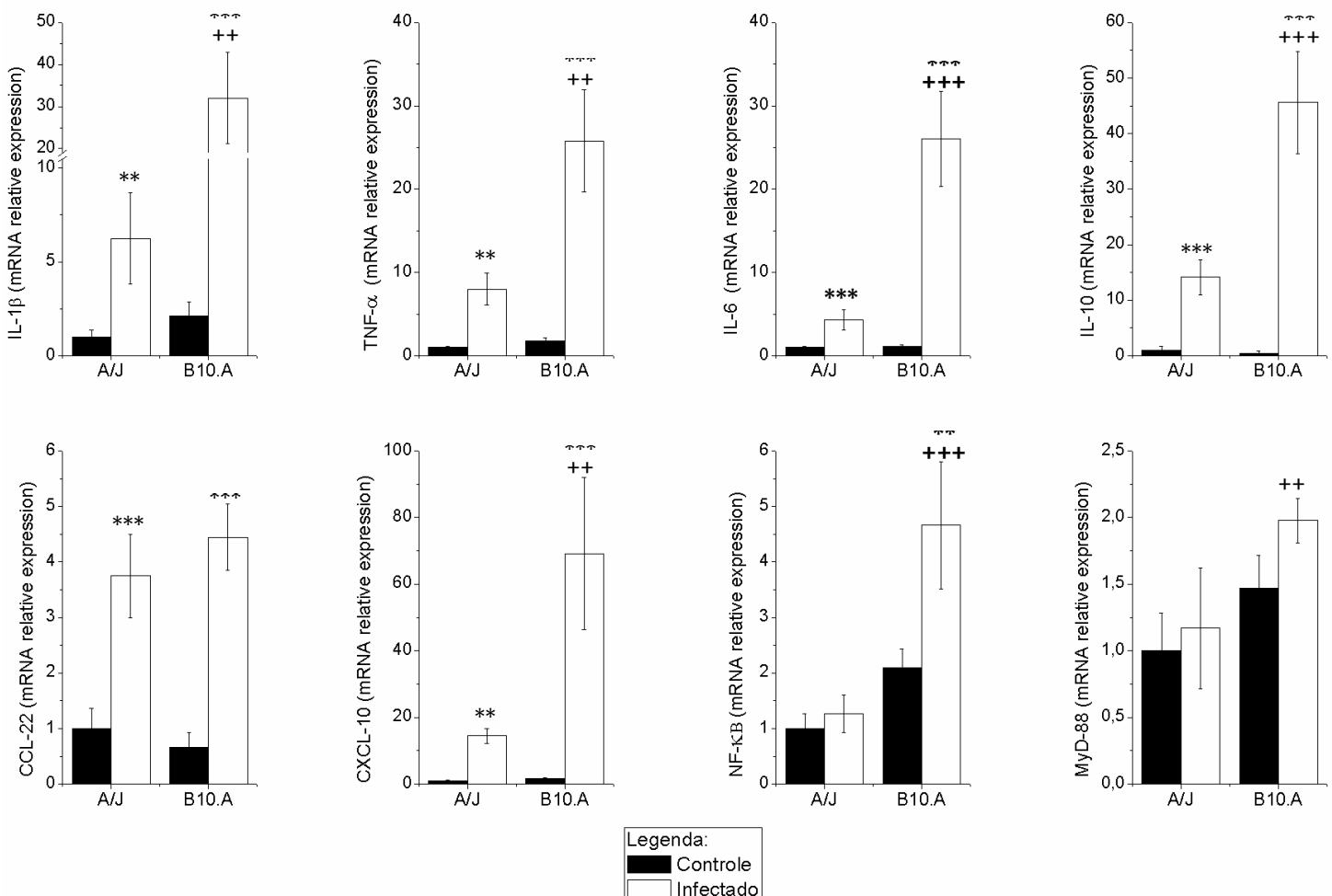

Figura 5.6. Acúmulo de transcritos de genes relacionados à resposta imune em BMDCs das linhagens A/J e B10.A após infecção por P. brasiliensis.

Após 6 h de interação com o isolado $\mathrm{Pb} 18$ de $P$. brasiliensis, o acúmulo relativo dos transcritos de citocinas (IL1 $\beta$, IL6, IL10 e TNF- $\alpha$ ), quimiocinas (CCL22 e CXCL10), do fator de transcrição NF- $\kappa B$ e da molécula adaptadora MyD88, foi determinado em relação ao gene endógeno RPS9. Como controle, avaliou-se os níveis dos transcritos em células BMDCs não infectadas. Os dados, representativos de três réplicas experimentais, foram expressos em médias $\pm \mathrm{SD}$, onde valores de $\mathrm{P}<0,05$ foram considerados significativos. $* \mathrm{P}<0,05, * * \mathrm{P}<0,01$ ou $* * * \mathrm{P}<0,001$ versus o seu próprio controle; $+\mathrm{P}<0,05,++\mathrm{P}<0,01$ ou $+++\mathrm{P}<0,001$ entre os grupos das diferente linhagem de camundongos.

Por outro lado, um panorama do perfil da transcrição das linhagens neste estudo, para todos os transcritos analisados, revelou o acúmulo notoriamente mais elevado de transcritos nas BMDCs oriundas da linhagem B10.A (suscetível) do que na linhagem A/J (resistente). De fato, resultados do grupo da Dra. Vera Calich sugerem que a linhagem suscetível B10.A monta uma resposta imune precoce mais exacerbada que a linhagem resistente $\mathrm{A} / \mathrm{J}$, o que resultaria em um desbalanço imunológico, acarretando danos ao hospedeiro (Calich et al. 2008). Em relação a expressão gênica de MyD88, vários fatores podem explicar a não modulação nos níveis do transcrito, tais quais o tempo no qual a análise foi realizada, podendo não coincidir com o pico de expressão gênica, ou mesmo a regulação ocorrer em nível 
pós-transcricional. Contudo, os dados provenientes do RNA-seq ainda encontram-se em fase de análise e devem ser explorados mais profundamente visando determinar se as diferenças no acúmulo de transcritos entre as duas linhagens é somente o nível de expressão (acumulo de transcritos) da reprogramação do transcritoma frente a infecção ou se linhagens resistentes e suscetíveis modulam a expressão gênica de forma diferencial.

Os sobrenadantes da cultura de BMDCs de camundongos das linhagem A/J (resistente) e B10.A (suscetível), infectadas ou não pelo isolado $\mathrm{Pb} 18$ de $\mathrm{P}$. brasiliensis por $6 \mathrm{~h}$, foram analisados para determinar diferenças na produção de citocinas (TNF- $\alpha$, IL-6, IL-10, IL-12, IL-17A e IL-23), e também da quimiocina MCP-1 (Figura 5.7). Os níveis de oxido nítrico (NO) no sobrenadante também foram analisados, empregando a reação de Griess (dados não mostrados). As análises tanto das citocinas quanto da produção de NO foram feitas com intuito de respaldar os resultados obtidos por qRT-PCR estabelecendo o contexto imunológico das células dendríticas de ambas linhagens após 6 h de infecção por $P$. brasiliensis.

Os resultados mostraram aumento dos níveis das citocinas TNF- $\alpha$, IL6 e IL10 secretadas por BMDCs de ambas as linhagens de camundongo quando da infecção por P. brasiliensis (Figura 5.6 e 5.7), corroborando os dados de expressão gênica. Ainda, tanto o acúmulo de transcritos, quanto a secreção destas citocinas é estatisticamente maior nas BMDCs originárias da linhagem B10.A (suscetível) quando comparado aos resultados obtidos para a linhagem A/J (resistente). Esse resultado corrobora os dados descritos na literatura, bem como a hipótese de que a linhagem suscetível B10.A apresenta uma resposta imune inata inicial mais intensa que a linhagem resistente $\mathrm{A} / \mathrm{J}$ frente à infecção por leveduras de $P$. brasiliensis (Calich et al. 2008, Almeida et al. 2001, Ferreira et al. 2007). Já a produção reduzida de citocinas na linhagem A/J pode ser explicada pelo relato de Cano et al. (1995), que descrevem uma eficiência na resposta de camundongos A/J somente após 8 semanas de infecção por P. brasiliensis. 
TNF- $\alpha$

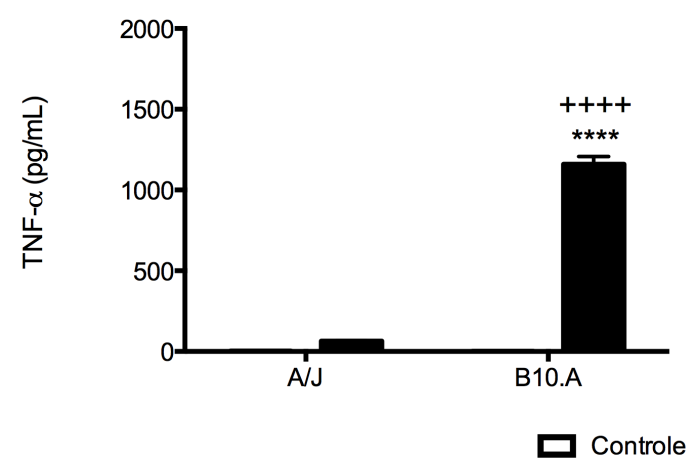

IL10

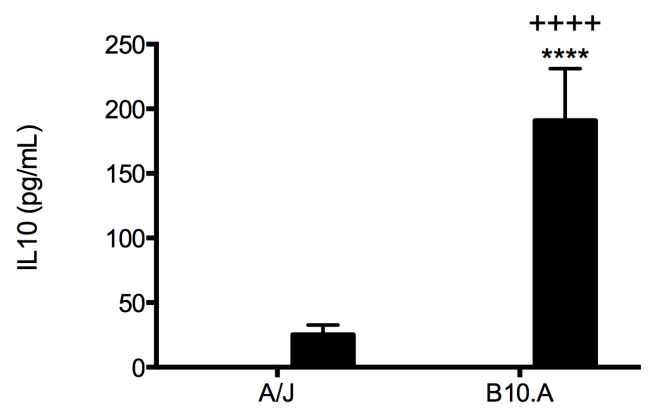

IL6

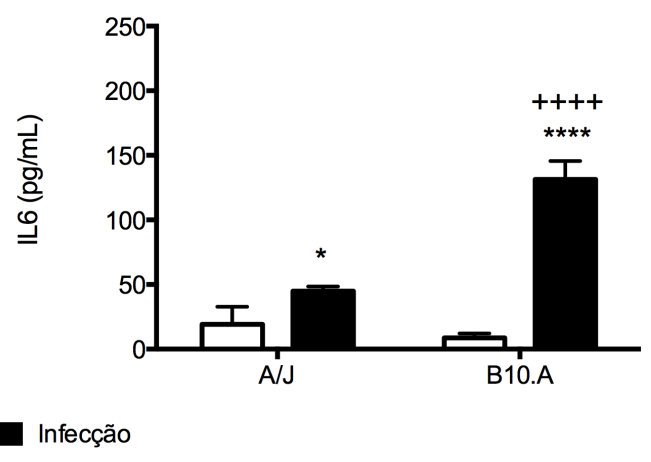

MCP-1

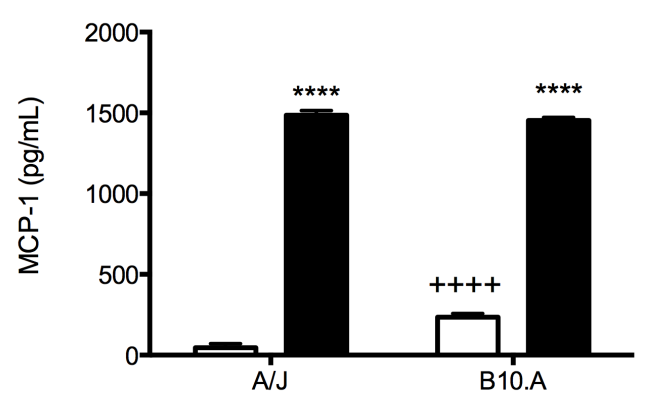

Figura 5.7. Quantificação da produção das citocinas TNF- $\alpha$ (a), IL-6 (b), IL-10 (c), e da quimiocina MCP-1 (d) por BMDCs de camundongos das linhagens resistente (A/J) e suscetível (B10.A) após 6h de infecção por $P$. brasiliensis.

Os dados, representativos de 3 replicatas experimentais, foram expressos em médias \pm $\mathrm{SD}$, onde valores de $\mathrm{P}<0,05$ foram considerados significativos. * $\mathrm{P}<0,05$, ** $\mathrm{P}<0,01$ ou $* * * \mathrm{P}<0,001$ versus o seu próprio controle; $+\mathrm{P}<0,05,++\mathrm{P}<0,01$ ou $+++\mathrm{P}$ $<0,001$ entre os grupos das diferente linhagem de camundongos.

Por outro lado, a secreção de MCP-1 (CCL2, monocyte chemoattractant protein-1) por BMDCs infectadas com P. brasiliensis foi significativamente maior em relação ao controle não infectado em ambas linhagens, porém sem diferença entre estas (Figura 5.7D). Esta quimiocina medeia a saída de monócitos a partir da medula óssea e o recrutamento destes para os tecidos inflamados através da interação com o receptor de quimiocina CCR2 (Sierra-Filardi et al. 2014). Sua expressão é regulada por citoquinas pró-inflamatórias (Sierra-Filardi et al. 2014). Isto sugere que embora ambas as linhagens de camundongos possuam a mesma capacidade de recrutar monócitos, há diferenças quanto ao nível de ativação dos mesmos (com base na produção das citocinas analisadas). Em contrapartida, uma maior produção de MCP-1 foi observada em macrófagos alveolares da linhagem B10.A (Pina et al. 2008)

Já os níveis de secreção da citocina IL-23 não apresentaram diferença significativa nem entre BMDCs de B10.A versus $\mathrm{A} / \mathrm{J}$, nem entre os grupos controle e 
infectado de cada linhagem. Além disso, nenhuma quantidade significativa das citocinas IL-12 e IL-17A e de NO foi detectado no tempo avaliado (dados não mostrados). Em relação à citocina IL-12, resultado similar, com 24h de infecção, foi obtido por Ferreira et al. (2007).

\subsection{Parte II: Caracterização de GM-BMM e M-BMM das Linhagens de Camundongos A/J E B10.A (Artigo)}

Como supracitado, nosso grupo está interessado em estudar a resposta imune inata do hospedeiro mamífero à $P$. brasiliensis. Nessa sessão, resumiremos os principais resultados publicados no artigo "The Effects of Paracoccidioides brasiliensis Infection on GM-CSF- and M-CSF-Induced Mouse Bone MarrowDerived Macrophage from Resistant and Susceptible Mice Strains". Cujo o foco era a compreensão do papel da polarização dos macrófagos nos fenótipos M1 (classicamente ativado)/M2 (alternativamente ativado) na resistência/suscetibilidade quanto ao modelo de PCM murino. Com este objetivo, após a comprovação da polarização dos macrófagos derivados de medula óssea (BMMs) induzidas por GMCSF (GM-BMMs - similar à M1) ou por M-CSF (M-BMMs - similar à M2) de ambas linhagens murinas A/J (resistente) e B10.A (suscetível) tanto por análises morfológicas como pelo perfil de expressão de genes marcadores da diferenciação de cada subtipo de macrófagos (ver artigo anexo), os GM- e M-BMMs foram infectaram in vitro com o isolado virulento de $P$. brasiliensis, $\mathrm{Pb} 18$.

O padrão de expressão gênica desses GM- e M-BMMs infectados em relação ao seu controle foi avaliado utilizando Antifungal Response $R T^{2}$ Profiler PCR Array (Quiagen). Esta matriz caracteriza os níveis de acúmulo de transcritos de 84 genes críticos da resposta imune inata de fungos patogênicos, cuja expressão diferencial encontra-se visualizado como mapa de calor (heatmap) na figura $5.8 \mathrm{~A}$ e o sumário modulação transcricional (induzido/reprimido) significativa em ambas linhagens de camundongos no diagrama de Venn (Figura 5.8B). Como se pode observar (Figura 5.8), ambas as linhagens modularam os genes diferencialmente após a exposição $6 \mathrm{~h}$ a 
P. brasiliensis em ambos os tipos de macrófagos induzidos. Para mais informações, no artigo anexo encontra-se tabelados em diferentes categorias funcionais selecionados genes modulados com base em estudos de interação entre fagócitos e fungos anteriores. Na figura 5.9 ilustra o modelo do conjunto de resultados obtidos para GM- e M-BMMs derivados de A/J e B10.A.
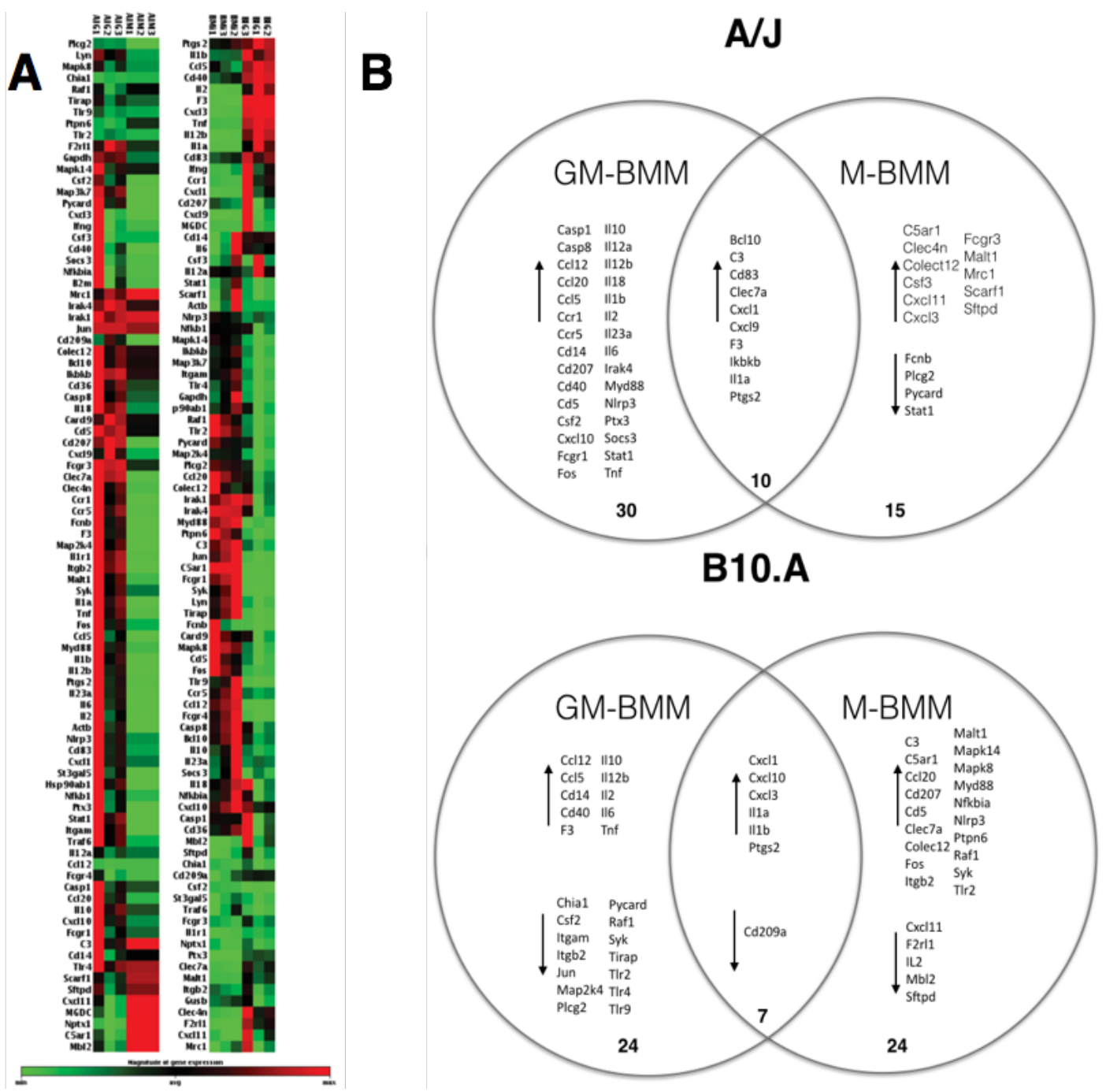

Figura 5.8. Perfis de Expressão genica baseados em Mouse Antifungal Response RTC Profiler TM PCR Array.

(A) Um mapa de calor foi gerado com 84 genes associados com a resposta antifúngica e cinco genes de housekeeping, usando RT² Profiler Data Analysis Software versão 3.5 com o painel PAMM 00147Z (SABiosciences). Os valores do fold change foram determinados para cada gene após sua normalização com acumulo o gene constitutivo Gusb (A/J) e B2m (B10.A) com uso do método de limiar comparativo. AIG 1, 2, 3 e AIM 1, 2, 3: representa um GM-BMM e M-BMM da linhagem murina de $\mathrm{A} / \mathrm{J}$, respectivamente, infectados com $P$. brasiliensis em relação às suas respectivas células de controle. BIG 1, 2, 3 e BIM 1, 2, 3: representa um GM-BMM e M-BMM da linhagem murina de A/J, respectivamente, infectados com $P$. brasiliensis em relação às suas respectivas células de controle. (B) Diagrama de Venn com os resultados de genes diferencialmente expressos $(\mathrm{P} \leq 0,05$; fold change $\geq 2)$ entre o grupo de não-infectados e infectado com P. brasiliensis de GM- ou M-BMM das linhagens de camundongos de $\mathrm{A} / \mathrm{J}$ e B10.A. 


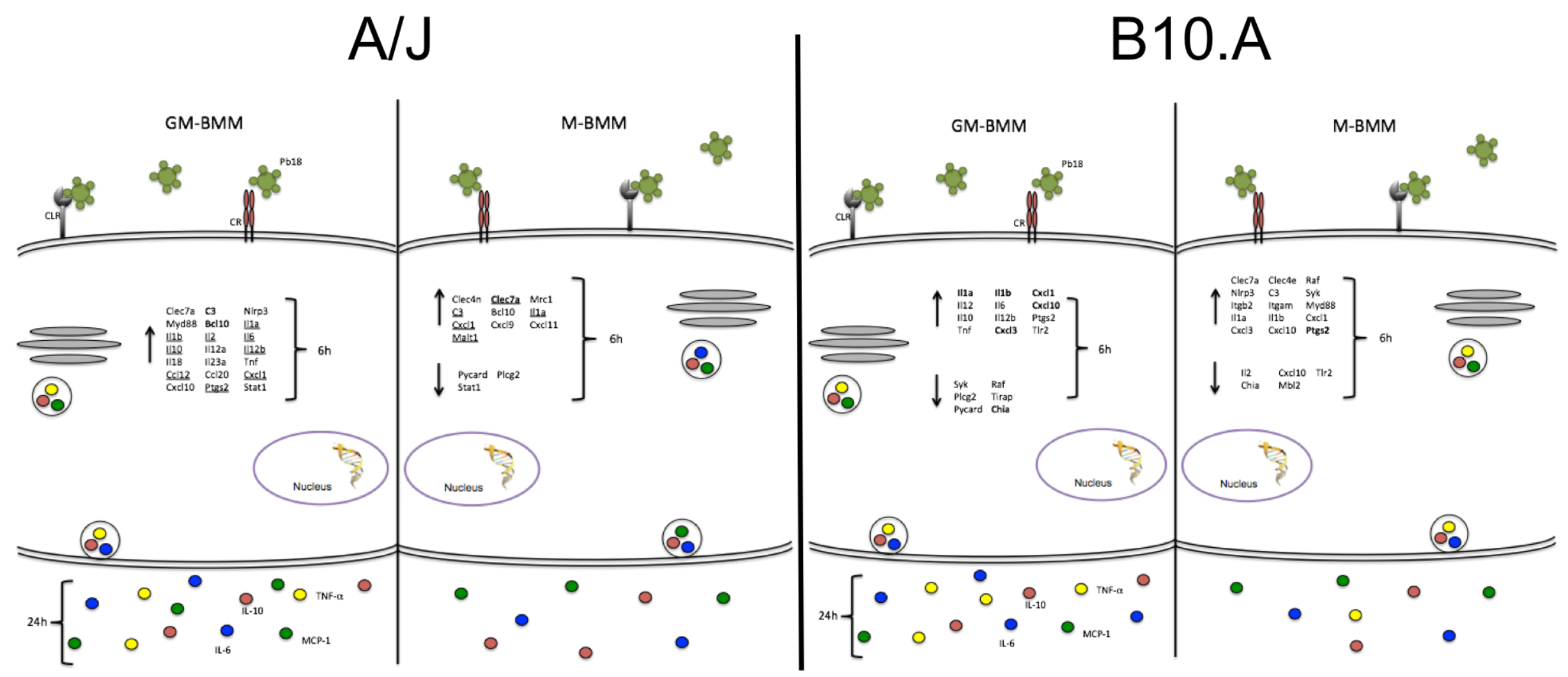

Figura 5.9. Representação esquemática dos principais resultados da expressão gênica e a produção de citocinas por GM- e M-BMMs das linhagens murinas A J e B10.A em resposta a infeç̧ão in vitro com Pb18.

As setas indicam os genes induzidos e reprimidos. Os círculos amarelos, vermelhos, verdes e azuis são representativos de TNF- $\alpha$, IL-10, MCP-1 e IL-6, respectivamente. Os genes em negrito indicam acúmulo de transcrito mais elevado na comparação entre GM- e M-BMM na mesma linhagem murina. Os genes sublinhados indicam que estes possuem o mesmo padrão de expressão entre GM- ou M-BMM das diferente linhagens de camundongos. 
Tal como anteriormente mencionado, os camundongos B10.A são conhecidos por sua susceptibilidade para $P$. brasiliensis e esta predisposição aparente baseia-se numa resposta imunitária inata inicialmente exacerbada mediada por macrófagos classicamente ativados (fenótipo similar a M1 - iNOS e SOCS3 elevados) e controle inicial de crescimento de fungos (Cano et al. 1995, Calich et al. 2008, Pina et al. 2008, Feriotti et al. 2013). Este controle inicial é posteriormente perdido permitindo a disseminação do fungo (Cano et al. 1995). Em nosso trabalho, GM-BMM de B10.A tem grande aumento nas quimiocinas de quimiotaxia granulócitos e citocinas inflamatórias (Figura 5.8 e Tabela no artigo anexo), em comparação com seus MBMMs. Dessa forma, essas observações estão de acordo com descrições relatadas anteriormente em que os macrófagos de B10.A, que tendem a polarizar a M1, são altamente inflamatórios (Calich et al. 1985, Calich et al. 1998, Calich et al. 2008, Pina et al. 2008, Feriotti et al. 2013). No entanto, os GM-BMM de B10.A apresentou uma diminuição no acúmulo dos transcritos associados com alguns dos TLRs, Dectina-1, na via de transdução de sinal complemento e em alguns associados com PRRs de fungos (Figura 5.8 e Tabela no artigo anexo). Isto significaria que estes macrófagos tem uma ativação deficiente/inferior devido a um reconhecimento truncado e, portanto, sem aprimoramento de uma resposta especifica. O que os tornaria, provavelmente, menos eficazes no controle de P. brasiliensis. Ao contrário, os MBMMs de B10.A, além de terem quimiocinas de quimiotaxia granulócitos elevadas a um determinado grau porem menos que GM-BMMs, também possuem estes transcritos elevados fúngicos (Figura 5.8 e Tabela no artigo anexo), e, assim, parece que estaria propenso a responder e se ativado ao entrar em contato com os fungos.

Por outro lado, os camundongos A/J estão associados com a resistência a PCM (Calich et al. 1985, Calich et al. 1998, Calich et al. 2008). Essa predisposição está marcada, tal como anteriormente referido, por resposta imune inata mediada por macrófagos alternativamente ativados (fenótipo similar a M2 - Arginase-1, FiZZ1, SOCS1 e YM1 elevado) e tolerância inicial ao crescimento fúngico (Cano et al. 1995, Calich et al. 2008, Pina et al. 2008, Feriotti et al. 2013). O que permitiria, em teoria, com o tempo, desenvolver um padrão de resistência mais robusto sem desligar a resposta imune pulmonar e, assim, controlar a disseminação do fungo. M-BMMs de $\mathrm{A} / \mathrm{J}$, em nosso estudo, apresentaram um aumento geral na resposta imune, tal como M-BMMs de B10.A, incluindo tanto os transcritos das quimiocinas associadas à 
quimiotaxia de granulócitos como alguns transcritos associados com TLRs, Dectina1, a via de transdução sinal complemento e em alguns outros associados a PRRs fúngicas (Figura 5.8 e Tabela no artigo anexo). Isto significaria que estes macrófagos podem ser mais facilmente ativados e assim responderem às mudanças no seu ambiente. Portanto, tornando-os, provavelmente, mais eficazes no controle e adaptação ao $P$. brasiliensis. No entanto, nos GM-BMMs de A/J, embora haja um grande aumento nos transcritos de quimiocinas e citocinas inflamatórias, não há nenhuma grande alteração no acúmulo de transcritos relacionados com qualquer via de transdução de sinal e em receptores de reconhecimento de padrões fúngicos (Figura 5.8 e Tabela no artigo anexo). O que significa que estes macrófagos são altamente inflamatórios, mas provavelmente têm uma resposta mais deficiente e ativação ineficiente ao interagir com $P$. brasiliensis. Mesmo assim, eles podem montar uma resposta mais adequada em comparação com GM-BMMs de B10.A, uma vez que não há uma diminuição efetiva de qualquer via de transdução de sinal e PRRs fúngicas.

Neste contexto, os nossos dados demonstram que a susceptibilidade e resistência estão fortemente associadas à polarização M1 e M2, respectivamente. 


\section{CONCLUSÃO}

Analisamos macrófagos (GM-BMM e M-BMM) e células dendríticas de camundongos resistentes $(\mathrm{A} / \mathrm{J})$ e susceptível (B10.A) à PCM a fim de compreender as bases moleculares da suscetibilidade do hospedeiro mamífero à infecção por Paracoccidioides brasiliensis. De forma geral, o transcritoma das BMDCs de A/J revelou que, além de padrão específico, apresenta pouca modulação da resposta imune mais organizada e direcionada. De fato, aparece não ter quase nem uma modulação de seus genes em relação ao controle. O que contribui para a ideia de uma resposta mais focada sem utilização e produção de recursos não necessários. Por outro lado, os BMDCs de B10.A modulam os seus genes de forma generalizada e desorganizada. Apesar da indução similar de vias de KEGG e termos GO, o numero de genes incluídos em cada categoria são mais números e as vezes com função contraditória (Tabela 5.3). Os genes das vias de KEGG reprimidas $(\mathrm{p}<0.05)$ no B10.A uma interfere com o funcionamento do lisossomo, e portanto no processamento de antígenos para apresentação, como também na via de sinalização de PPAR, que a foi comprovada sua importância na resistência a candidíases. A ultima esta relaciona da degradação dos aminoácidos valina, leucina e isoleucina cuja sua função na susceptibilida/resistência ainda não ha sido comprovada. Cabe destacar vários genes que foram induzidos/reprimidos não foram estatisticamente sobre-representadas em num categoria, o implicaria uma modulação possivelmente aleatória de genes. Um aprofundamento desses dados esta em andamento para o artigo em produção.

Os macrófagos de ambos os tipo de diferenciação, em geral mostraram o mesmo padrão. Os níveis de transcrição de IL-2, IL-6, IL-10, IL-12 e TNF- $\alpha$ estavam aumentados em GM-BMMs (tipo M1) de ambas linhagens quando comparado com M-BMMs (tipo M2). GM-BMM de B10.A apresentou uma diminuição em alguns transcritos associados às vias de sinalização de TLR, Dectina-1 e complemento e também em alguns PRRs associados a fungos. Enquanto $\mathrm{A} / \mathrm{J}$ GM-BMM não apresentaram nehuma grande alteração no número de transcritos relacionadas com qualquer via de transdução de sinal e na PRRs fúngicas. Os macrófagos M-BMM da linhagem murina B10.A tiveram os transcritos de quimiocinas relacionadas à quimiotaxia granulócitos elevada. Da mesma forma, M-BMM de A/J apresentou um aumento geral de transcritos da resposta imunitária, incluindo quimiocinas 
relacionadas à quimiotaxia granulócitos, transcritos associados com algumas vias de transdução de sinal dos TLRs, Dectina-1, e complemento e em alguns PRRs associados com reconhecimento fúngico. Os nossos dados demonstram que tanto a susceptibilidade como a resistência estão fortemente associadas à polarização M1 e M2, sendo a polarização à M2 aparentemente mais eficiente em ambas linhagens na identificação e portanto modulação da resposta (PRRs elevados, $\mathrm{A} / \mathrm{J}$, ou não modulado, B10.A). No entanto, sem importar a diferenciação do macrófago, o BMMs do $\mathrm{A} / \mathrm{J}$ parece ter melhor adaptabilidade que os de B10.A.

Cabe destacar que ambos estudos são um retrato funcional de um momento especifico da interação que em conjunto com outros dados da literatura vem a adicionar mais informações sobre a resposta a infecção inicial e seu efeito no direcionamento da resposta imune posterior. Em efeito, a imunidade inata além de orquestrar a resposta inicial e modelar a resposta adaptativa, ela não é inativada ate a resolução do problema que a ativou. Ela permanece acompanhado a imunidade adaptativa recebendo sinais do ambiente modulando-a conforme o processo se desenvolve. Por tanto, seria racional pensar que uma compressão de seu funcionamento ajudaria criar protocolos para imunomodular a resposta em qualquer etapa da infecção, seja inicial ou posterior. Por isso a importância de mais estudos relacionados a resposta imune inata e suas modulações diferenciais. 


\section{REFERÊNCIAS}

Adany I, Yazlovitskaya EM, Haug JS, Voziyan PA, Melnykovych G. 1994. Differences in sensitivity to farnesol toxicity between neoplastically- and nonneoplastically-derived cells in culture. Cancer Lett 79: 175-9

Aderem A, Adkins J, Ansong C, Galagan J, Kaiser S, Korth M, Law G, McDermott J, Proll S, Rosenberger C, Schoolnik G, Katze M. 2011. A systems biology approach to infectious disease research: innovating the pathogen-host research paradigm. mBio 2: 10

Ali Z, Ali A, Tempest M, Wiselka M. 2003. Invasive pulmonary aspergillosis complicating chronic obstructive pulmonary disease in an immunocompetent patient. J Postgrad Med. 49(1):78-80

Almeida SR, Lopes JD. 2001. The low efficiency of dendritic cells and macrophages from mice susceptible to Paracoccidioides brasiliensis in inducing a Th1 response. Braz J Med Biol Res 34: 529-37

Anders, S., Pyl, P.T., Huber, W., 2014. HTSeq-a Python framework to work with high-throughput sequencing data. Bioinformatics.

Andrews, S., 2010. FastQC: A quality control tool for high throughput sequence data. Reference Source.

Arora S, Olszewski MA, Tsang TM, McDonald RA, Toews GB, Huffnagle GB. 2011. Effect of cytokine interplay on macrophage polarization during chronic pulmonary infection with Cryptococcus neoformans. Infect. Immun. 79:19151926.

Benard G. 2008. An overview of the immunopathology of human paracoccidioidomycosis. Mycopathologia 165: 209-21

Bagagli E, Bosco SM, Theodoro RC, Franco M. 2006. Phylogenetic and evolutionary aspects of Paracoccidioides brasiliensis reveal a long coexistence with animal hosts that explain several biological features of the pathogen. Infect Genet Evol 6: 344-51

Bagagli E, Theodoro RC, Bosco SM, McEwen JG. 2008. Paracoccidioides brasiliensis: phylogenetic and ecological aspects. Mycopathologia 165: 197-207

Baumgardner DJ, Paretsky DP. 1999. The in vitro isolation of Blastomyces dermatitidis from a woodpile in north central Wisconsin, USA. Med Mycol 37: $163-8$

Bethlem NM, Lemle A, Bethlem E, Wanke B. 1999. Paracoccidioidomycosis. Curr Opin Pulm Med 5: 319-325.

Bernin H, Lotter H. 2014. Sex bias in the outcome of human tropical infectious diseases: influence of steroid hormones. J Infect Dis 15(Suppl 3): S107-S113. 
Bigliazzi C, Poletti V, Dell'Amore D, Saragoni L, Colby T. 2004. Disseminated basidiobolomycosis in an immunocompetent woman. Journal of clinical microbiology 42: 1367-9

Boesten R, de Vos W. 2008. Interactomics in the human intestine: Lactobacilli and Bifidobacteria make a difference. Journal of clinical gastroenterology 42 Suppl 3 Pt 2: 7

BRASIL. Ministério da Saúde. PORTARIA No 1.271, DE 6 DE JUNHO DE 2014. Define a Lista Nacional de Notificação Compulsória de doenças, agravos e eventos de saúde pública nos serviços de saúde públicos e privados em todo o território nacional, nos termos do anexo, e dá outras providências. DOU p.67-69, seção 1, 09/06/2014.

Brown, G. D., Denning, D. W., \& Levitz, S. M. (2012). Tackling human fungal infections. Science, 336(6082), 647-647.

Brown, G. D., \& Netea, M. G. (2012). Exciting developments in the immunology of fungal infections. Cell host \& microbe, 11(5), 422-424.

Brummer E, Hanson LH, Stevens DA. 1988. Gamma-interferon activation of macrophages for killing of Paracoccidioides brasiliensis and evidence for nonoxidative mechanisms. Int J Immunopharmacol 10: 945-52

Brummer E, Hanson LH, Restrepo A, Stevens DA. 1989. Intracellular multiplication of Paracoccidioides brasiliensis in macrophages: killing and restriction of multiplication by activated macrophages. Infect Immun 57: 2289-94

Brummer E, Sun SH, Harrison JL, Perlman AM, Philpott DE, Stevens DA. 1990. Ultrastructure of phagocytosed Paracoccidioides brasiliensis in nonactivated or activated macrophages. Infect Immun 58: 2628-36

Brummer E, Castaneda E, Restrepo A. 1993. Paracoccidioidomycosis: an update. Clin Microbiol Rev 6: 89-117

Brummer E. 1994. Interaction of Paracoccidioides brasiliensis with host defense cells. CRC Press, Boca Raton, FL

Candela M, Guidotti M, Fabbri A, Brigidi P, Franceschi C, Fiorentini C. 2011. Human intestinal microbiota: cross-talk with the host and its potential role in colorectal cancer. Critical reviews in microbiology 37: 1-14

Cano LE, Arango R, Salazar ME, Brummer E, Stevens DA, Restrepo A. 1992. Killing of Paracoccidioides brasiliensis conidia by pulmonary macrophages and the effect of cytokines. J Med Vet Mycol 30: 161-8

Cano LE, Gomez B, Brummer E, Restrepo A, Stevens DA. 1994. Inhibitory effect of deferoxamine or macrophage activation on transformation of Paracoccidioides brasiliensis conidia ingested by macrophages: reversal by holotransferrin. Infect Immun 62: 1494-6 
Cano L, Singer-Vermes L, Vaz C, Russo M, Calich V. 1995. Pulmonary paracoccidioidomycosis in resistant and susceptible mice: relationship among progression of infection, bronchoalveolar cell activation, cellular immune response, and specific isotype patterns. Infection and immunity 63: 1777-83

Calich VL, Singer-Vermes LM, Siqueira AM, Burger E. 1985. Susceptibility and resistance of inbred mice to Paracoccidioides brasiliensis. Br J Exp Pathol 66: 585-94

Calich VLG, Singer-Vermes LM, Russo M, Vaz C, Burger E, Franco M, Lacaz CS, Restrepo A, Del Negro G. 1994. Immunogenetics in paracoccidioidomycosis. CRC Press, Boca Raton, FL

Calich VL, Vaz CA, Burger E. 1998a. Immunity to Paracoccidioides brasiliensis infection. Res Immunol 149: 407-17; discussion 99-500

Calich V, Kashino S. 1998. Cytokines produced by susceptible and resistant mice in the course of Paracoccidioides brasiliensis infection. Braz J Med Biol Res. 31(5):615-23.

Calich VL, da Costa TA, Felonato M, Arruda C, Bernardino S, Loures FV, Ribeiro LR, de Cassia Valente-Ferreira R, Pina A. 2008. Innate immunity to Paracoccidioides brasiliensis infection. Mycopathologia 165: 223-36

Carpenter S, Ricci EP, Mercier BC, Moore MJ and Fitzgerald KA. 2014. Posttranscriptional regulation of gene expression in innate immunity. Nature Rev. Immunol. 14, 361-376.

Carpenter S, Fitzgerald KA. 2015. Transcription of inflammatory genes: long noncoding RNA and beyond. J Interferon Cytokine Res. 35(2):79-88. doi: 10.1089/jir.2014.0120.

Carrillo-Munoz AJ, Giusiano G, Ezkurra PA, Quindos G. 2006. Antifungal agents: mode of action in yeast cells. Rev Esp Quimioter 19: 130-9

Chakrabarti A. 2005. Microbiology of systemic fungal infections. Journal of postgraduate medicine 51 Suppl 1: 20

Chen J, Varma A, Diaz MR, Litvintseva AP, Wollenberg KK, Kwon-Chung KJ (2008). Cryptococcus neoformans strains and infection in apparently immunocompetent patients, China. Emerg. Infect. Dis. 14:755-762.

Cloonan N, Grimmond SM. 2008. Transcriptome content and dynamics at singlenucleotide resolution. Genome Biol 9: 234

Cock, P.J., Fields, C.J., Goto, N., Heuer, M.L., Rice, P.M., 2010. The Sanger FASTQ file format for sequences with quality scores, and the Solexa/Illumina FASTQ variants. Nucleic acids research 38, 1767-1771.

Colombo AL, Tob_on A, Restrepo A, Queiroz-Telles F, Nucci M. 2011. Epidemiology of endemic systemic fungal infections in Latin America. Med Mycol 49, 785-798. 
Coutinho ZF, Silva D, Lazera M, Petri V, Oliveira RM, Sabroza PC, Wanke B. 2002. Paracoccidioidomycosis mortality in Brazil (1980-1995). Cad Saude Publica 18: $1441-54$

Coutinho ZF, Wanke B, Travassos C, Oliveira RM, Xavier DR, Coimbra CE Jr. (2015) Hospital morbidity due to paracoccidioidomycosis in Brazil (1998-2006). Trop Med Int Health. 20(5):673-680.

Costa EO, Diniz LS, Netto CF. 1995a. The prevalence of positive intradermal reactions to paracoccidioidin in domestic and wild animals in Sao Paulo, Brazil. Vet Res Commun 19: 127-30

Costa EO, Diniz LS, Netto CF, Arruda C, Dagli ML. 1995b. Delayed hypersensitivity test with paracoccidioidin in captive Latin American wild mammals. J Med Vet Mycol 33: 39-42

Costa TA, Bazan SB, Feriotti C, Araújo EF, Bassi Ê, Loures FV, Calich VL. 2013. In pulmonary paracoccidioidomycosis IL-10 deficiency leads to increased immunity and regressive infection without enhancing tissue pathology._PLoS Negl Trop Dis.7(10):e2512

Costa V, Angelini C, De Feis I and Ciccodicola A. 2010. Uncovering the complexity of transcriptomes with RNA-Seq. J. Biomed. Biotechnol. $2010,853916$.

Coste, A., Dubourdeau, M., Linas, M. D., Cassaing, S., Lepert, J. C., Balard, P., ... \& Pipy, B. (2003). PPAR $\gamma$ promotes mannose receptor gene expression in murine macrophages and contributes to the induction of this receptor by IL-13. Immunity, 19(3), 329-339.

Cummings CA, Relman DA. 2000. Using DNA microarrays to study host-microbe interactions. Emerg Infect Dis 6: 513-25

Dambuza IM, Brown GD. 2015. C-type lectins in immunity: recent development. Curr Opin Immunol. 32:21-7.

Davis MJ, Tsang TM, Qiu Y, Dayrit JK, Freij JB, Huffnagle GB, Olszewski MA. (2013) Macrophage M1/M2 polarization dynamically adapts to changes in cytokine microenvironments in Cryptococcus neoformans infection. MBio.18; 4(3):e00264-13.

Daubeuf F, Frossard N. 2012. Performing Bronchoalveolar Lavage in the Mouse. Current Protocols in Mouse Biology

Daynes, R. A., \& Jones, D. C. (2002). Emerging roles of PPARs in inflammation and immunity. Nature Reviews Immunology, 2(10), 748-759.

de Almeida S, de Moraes J, de Camargo Z, Gesztesi J, Mariano M, Lopes J. 1998. Pattern of immune response to GP43 from Paracoccidioides brasiliensis in susceptible and resistant mice is influenced by antigen-presenting cells. Cellular immunology 190: 68-76

de Sousa Abreu, R., Penalva, L. O., Marcotte, E. M. \& Vogel, C. 2009. Global signatures of protein and mRNA expression levels. Mol. Biosyst. 5, 1512-1526. 
Deshmane S, Kremlev S, Amini S, Sawaya B. 2009. Monocyte chemoattractant protein-1 (MCP-1): an overview. Journal of interferon \& cytokine research : the official journal of the International Society for Interferon and Cytokine Research 29: $313-26$

Dignani MC (2014). Epidemiology of invasive fungal diseases on the basis of autopsy reports. F1000Prime Rep. 2014 Sep 4;6:81.

Drummond RA, Saijo S, Iwakura Y, Brown GD. 2011. The role of Syk/CARD9 coupled C-type lectins in antifungal immunity. Eur J Immunol. 41(2):276-81.

Drummond RA, Gaffen SL, Hise AG, Brown GD. 2014 Innate Defense against Fungal Pathogens. Cold Spring Harb Perspect Med. 5(6). pii: a019620.

Fava Netto, C., 1955. Estudos quantitativos sobre a fixação do complemento na blastomicose sul-americana, com antígeno polissacarídico. Arq Cir Clin Exp 18, 242.

Ferreira K, Lopes... J. 2003. Regulation of T Helper Cell Differentiation In Vivo by GP43 from Paracoccidioides brasiliensis Provided by Different Antigen Presenting Cells. Scandinavian journal of ...

Ferreira KS, Lopes JD, Almeida SR. 2004. Down-regulation of dendritic cell activation induced by Paracoccidioides brasiliensis. Immunol Lett 94: 107-14

Ferreira KS, Almeida SR. 2006. Immunization of susceptible mice with gp43-pulsed dendritic cells induce an increase of pulmonary Paracoccidioidomycosis. Immunol Lett 103: 121-6

Ferreira KS, Bastos KR, Russo M, Almeida SR. 2007. Interaction between Paracoccidioides brasiliensis and pulmonary dendritic cells induces interleukin10 production and toll-like receptor-2 expression: possible mechanisms of susceptibility. J Infect Dis 196: 1108-15

Feriotti C, Loures FV, Frank de Araujo E, da Costa TA, Calich VL. 2013. Mannosylrecognizing receptors induce an M1-like phenotype in macrophages of susceptible mice but an M2-like phenotype in mice resistant to a fungal infection. PLoS One 8: e54845

Fieschi C, Casanova J-L. 2003. The role of interleukin-12 in human infectious diseases: only a faint signature. European journal of immunology 33: 1461-4

Filler SG, Sheppard DC. 2006. Fungal invasion of normally non-phagocytic host cells. PLoS Pathog 2: e129

Fleetwood, A. J., T. Lawrence, J. A. Hamilton, and A. D. Cook. 2007. Granulocytemacrophage colony-stimulating factor (CSF) and macrophage CSF-dependent macrophage phenotypes display differences in cytokine profiles and transcription factor activities: implications for CSF blockade in inflammation. J. Immunol. 178: $5245-5252$. 
Fleetwood AJ, Dinh H, Cook AD, Hertzog PJ, Hamilton JA. 2009. GM-CSF- and MCSF-dependent macrophage phenotypes display differential dependence on type I interferon signaling. J Leukoc Biol 86: 411-21

Flicek P, Amode M, Barrell D, Beal K, Brent S, Carvalho-Silva D, Clapham P, Coates G, Fairley S, Fitzgerald S, Gil L, Gordon L, Hendrix M, Hourlier T, Johnson N, Kähäri A, Keefe D, Keenan S, Kinsella R, Komorowska M, Koscielny G, Kulesha E, Larsson P, Longden I, McLaren W, Muffato M, Overduin B, Pignatelli M, Pritchard B, Riat H, Ritchie G, Ruffier M, Schuster M, Sobral D, Tang Y, Taylor K, Trevanion S, Vandrovcova J, White S, Wilson M, Wilder S, Aken B, Birney E, Cunningham F, Dunham I, Durbin R, Fernández-Suarez X, Harrow J, Herrero J, Hubbard T, Parker A, Proctor G, Spudich G, Vogel J, Yates A, Zadissa A, Searle S. 2012. Ensembl 2012. Nucleic acids research 40: 90

Franco M. 1987. Host-parasite relationships in paracoccidioidomycosis. J Med Vet Mycol 25: 5-18

Franco M, Bagagli E, Scapolio S, da Silva Lacaz C. 2000. A critical analysis of isolation of Paracoccidioides brasiliensis from soil. Med Mycol 38: 185-91

Gasser A, Möst J. 1999. Generation of multinucleated giant cells in vitro by culture of human monocytes with Mycobacterium bovis BCG in combination with cytokinecontaining supernatants. Infect Immun. 67(1):395-402.

Galès, A., Conduché, A., Bernad, J., Lefevre, L., Olagnier, D., Béraud, M., ... \& Pipy, B. (2010). PPARgamma controls dectin-1 expression required for host antifungal defense against Candida albicans. PLoS Pathog, 6(1), e1000714.

Goihman-Yahr M, Pine L, Albornoz MC, Yarzabal L, de Gomez MH, San Martin B, Ocanto A, Molina T, Convit J. 1980. Studies on plating efficiency and estimation of viability of suspensions of Paracoccidioides brasiliensis yeast cells. Mycopathologia 71: 73-83

Gómez-Díaz, E., Jordà, M., Peinado, M. A., \& Rivero, A. (2012). Epigenetics of host-pathogen interactions: the road ahead and the road behind.

Gonzalez A, de Gregori W, Velez D, Restrepo A, Cano LE. 2000. Nitric oxide participation in the fungicidal mechanism of gamma interferon-activated murine macrophages against Paracoccidioides brasiliensis conidia. Infect Immun 68: 2546-52

González A, Yáñez A, Gozalbo D, Gil M. 2008. MyD88 is dispensable for resistance to Paracoccidioides brasiliensis in a murine model of blood-borne disseminated infection. FEMS immunology and medical microbiology 54: 365-74

Gosalbes M, Durbán A, Pignatelli M, Abellan J, Jiménez-Hernández N, Pérez-Cobas A, Latorre A, Moya A. 2011. Metatranscriptomic approach to analyze the functional human gut microbiota. PLoS One 6

Gringhuis SI, den Dunnen J, Litjens M, van der Vlist M, Wevers B, Bruijns SC, Geijtenbeek TB. 2009. Dectin-1 directs T helper cell differentiation by controlling 
noncanonical NF-kappaB activation through Raf-1 and SyK. Nat Immunol. 10(2):203-13

Gupta AK, Tomas E. 2003. New antifungal agents. Dermatol Clin 21: 565-76

Herzenberg L, Tung... J. 2006. Interpreting flow cytometry data: a guide for the perplexed. Nature ...

Hoffmann S, Otto C, Kurtz S, Sharma C, Khaitovich P, Vogel J, Stadler P, Hackermüller J. 2009. Fast mapping of short sequences with mismatches, insertions and deletions using index structures. PLoS computational biology 5

Horrocks N, Matson K, Tieleman B. 2011. Pathogen pressure puts immune defense into perspective. Integrative and comparative biology 51: 563-76

Ho VW, Sly LM. 2009. Derivation and characterization of murine alternatively activated (M2) macrophages. Methods Mol Biol. 531:173-85

Hotez PJ, Bottazzi ME, Franco-Paredes C, Ault SK, Periago MR. The neglected tropical diseases of Latin America and the Caribbean: a review of disease burden and distribution and a road map for control and elimination. PLoS Negl Trop Dis 2008; 2(9):e300.

Huang, D. W., Sherman, B. T., Zheng, X., Yang, J., Imamichi, T., Stephens, R., \& Lempicki, R. A. (2009). Extracting biological meaning from large gene lists with DAVID. Current protocols in bioinformatics, 13-11.

Iwakura Y, Ishigame H. 2006. The IL-23/IL-17 axis in inflammation. Journal of Clinical Investigation

Iwakura Y, Nakae S, Saijo S, Ishigame H. 2008. The roles of IL-17A in inflammatory immune responses and host defense against pathogens. Immunological reviews 226: $57-79$

Janeway CA, Travers P, Walport M, Capra JD. 2001. Immunobiology: the immune system in health and disease. Current Biology 1

Jenner RG, Young RA. 2005. Insights into host responses against pathogens from transcriptional profiling. Nat Rev Microbiol 3: 281-94

Jimenez B, Murphy J. 1984. In vitro effects of natural killer cells against Paracoccidioides brasiliensis yeast phase. Infection and immunity 46: 552-8

Idnurm A, Bahn Y-S, Nielsen K, Lin X, Fraser J, Heitman J. 2005. Deciphering the model pathogenic fungus Cryptococcus neoformans. Nature reviews. Microbiology 3: 753-64

Kashino SS, Fazioli Rdos A, Moscardi-Bacchi M, Franco M, Singer-Vermes LM, Burger E, Calich VL. 1995. Effect of macrophage blockade on the resistance of inbred mice to Paracoccidioides brasiliensis infection. Mycopathologia 130: 13140

Kashino SS, Fazioli RA, Cafalli-Favati C, Meloni-Bruneri LH, Vaz CA, Burger E, Singer LM, Calich VL. 2000. Resistance to Paracoccidioides brasiliensis infection 
is linked to a preferential Th1 immune response, whereas susceptibility is associated with absence of IFN-gamma production. J Interferon Cytokine Res 20: 89-97

Kauffman CA. 2006. Fungal infections. Proc Am Thorac Soc 3: 35-40

Keane TM, Goodstadt L, Danecek P, White MA, Wong K, Yalcin B, Heger A, Agam A, Slater G, Goodson M, Furlotte NA, Eskin E, Nellåker C, Whitley H, Cleak J, Janowitz D, Hernandez-Pliego P, Edwards A, Belgard TG, Oliver PL, McIntyre RE, Bhomra A, Nicod J, Gan X, Yuan W, van der Weyden L, Steward CA, Bala S, Stalker J, Mott R, Durbin R, Jackson IJ, Czechanski A, Guerra-Assunção JA, Donahue LR, Reinholdt LG, Payseur BA, Ponting CP, Birney E, Flint J, Adams DJ. 2011. Mouse genomic variation and its effect on phenotypes and gene regulation. Nature 477(7364):289-94.

Kim, D., Pertea, G., Trapnell, C., Pimentel, H., Kelley, R., Salzberg, S.L., 2013. TopHat2: accurate alignment of transcriptomes in the presence of insertions, deletions and gene fusions. Genome biology 14, R36.

Kirkland TN, Fierer J. 1996. Coccidioidomycosis: a reemerging infectious disease. Emerg Infect Dis 2: 192-9

Klein B, Tebbets B. 2007. Dimorphism and virulence in fungi. Current opinion in microbiology

Kurita N, Oarada M, Miyaji M, Ito E. 2000. Effect of cytokines on antifungal activity of human polymorphonuclear leucocytes against yeast cells of Paracoccidioides brasiliensis. Medical mycology : official publication of the International Society for Human and Animal Mycology 38: 177-82

Kurokawa CS, Lopes CR, Sugizaki MF, Kuramae EE, Franco MF, Peracoli MT. 2005. Virulence profile of ten Paracoccidioides brasiliensis isolates: association with morphologic and genetic patterns. Rev Inst Med Trop Sao Paulo 47: 257-62

Kurokawa CS, Araujo JP Jr, Soares AM et al. 2007. Pro- and anti-inflammatory cytokines produced by human monocytes challenged in vitro with Paracoccidioides brasiliensis. Microbiol Immunol 51(4):421-428.

Lacey DC, Achuthan A, Fleetwood AJ, Dinh H, Roiniotis J, Scholz GM, Chang MW, Beckman SK, Cook AD, Hamilton JA. 2012. Defining GM-CSF- and macrophage-CSF-dependent macrophage responses by in vitro models. J Immunol 188: 5752-65

Lambrecht BN, Prins JB, Hoogsteden HC. 2001. Lung dendritic cells and host immunity to infection. Eur Respir J 18: 692-704

Lambrecht B. 2006. Alveolar macrophage in the driver's seat. Immunity 24: 366-8 
Langenkamp A, Messi M, Lanzavecchia A, Sallusto F. 2000. Kinetics of dendritic cell activation: impact on priming of TH1, TH2 and nonpolarized T cells. Nature immunology 1: 311-6

Lemberger, T., Desvergne, B., \& Wahli, W. (1996). Peroxisome proliferator-activated receptors: a nuclear receptor signaling pathway in lipid physiology. Annual review of cell and developmental biology, 12(1), 335-363.

Lefevre, L., Gales, A., Olagnier, D., Bernad, J., Perez, L., Burcelin, R., ... \& Coste, A. (2010). PPARgamma ligands switched high fat diet-induced macrophage M2b polarization toward M2a thereby improving intestinal Candida elimination. PLoS One, 5(9), e12828.

Li, H., Handsaker, B., Wysoker, A., Fennell, T., Ruan, J., Homer, N., Marth, G., Abecasis, G., Durbin, R., 2009. The Sequence Alignment/Map format and SAMtools. Bioinformatics 25, 2078-2079.

Liese B, Rosenberg M, Schratz A. Programmes, partnerships, and governance for elimination and control of neglected tropical diseases. Lancet 2010; 375:67-76.

Livak KJ, Schmittgen TD. 2001. Analysis of relative gene expression data using realtime quantitative PCR and the 2(-Delta Delta C(T)). Methods. 25(4):402-8.

Longhi L, da Silva R, Fornazim M, Spago M, de Oliveira R, Nowill A, Blotta M, Mamoni R. 2012. Phenotypic and functional characterization of NK cells in human immune response against the dimorphic fungus Paracoccidioides brasiliensis. Journal of immunology (Baltimore, Md. : 1950) 189: 935-45

Loures F, Pina A, Felonato M, Feriotti C, de Araújo E, Calich V. 2011. MyD88 signaling is required for efficient innate and adaptive immune responses to Paracoccidioides brasiliensis infection. Infection and immunity 79: 2470-80

Loures FV, Araújo EF, Feriotti C, Bazan SB, Costa TA, Brown GD, Calich VL. 2014. Dectin-1 induces M1 macrophages and prominent expansion of CD8+IL-17+ cells in pulmonary Paracoccidioidomycosis. J Infect Dis. 210(5):762-73.

Lutz M, Kukutsch N, Ogilvie A, Rößner... S. 1999. An advanced culture method for generating large quantities of highly pure dendritic cells from mouse bone marrow. Journal of

Lynch KW. 2004. Consequences of regulated pre-mRNA splicing in the immune system. Nat Rev Immunol 4: 931-40

MacLean D, Jones JD, Studholme DJ. 2009. Application of 'next-generation' sequencing technologies to microbial genetics. Nat Rev Microbiol 7: 287-96

Maier, T., Guell, M. \& Serrano, L. 2009. Correlation of mRNA and protein in complex biological samples. FEBS Lett. 583, 3966-3973.

Maldonado-Lopez R, Moser M. 2001. Dendritic cell subsets and the regulation of Th1/Th2 responses. Semin Immunol 13: 275-82

Mantovani A, Sica A, Locati M. 2005. Macrophage polarization comes of age. Immunity. 23(4):344-6. Review. 
Marioni JC, Mason CE, Mane SM, Stephens M, Gilad Y. 2008. RNA-seq: an assessment of technical reproducibility and comparison with gene expression arrays. Genome Res 18: 1509-17

Martin, M., 2011. Cutadapt removes adapter sequences from high-throughput sequencing reads. EMBnet journal 17, pp. 10-12.

Martinez R. 2010. Paracoccidioidomycosis: the dimension of the problem of a neglected disease. Rev Soc Bras Med Trop. 43(4):480.

Martinez, F. O., \& Gordon, S. (2014). The M1 and M2 paradigm of macrophage activation: time for reassessment. F1000prime reports, 6 .

McEwen J, Brummer E, Stevens D, Restrepo A. 1987. Effect of murine polymorphonuclear leukocytes on the yeast form of Paracoccidioides brasiliensis [corrected]. The American journal of tropical medicine and hygiene 36: 603-8

McEwen JG, Garcia AM, Ortiz BL, Botero S, Restrepo A. 1995. In search of the natural habitat of Paracoccidioides brasiliensis. Arch Med Res 26: 305-6

McWhorter FY, Wang T, Nguyen P, Chung T, Liu WF. 2013. Modulation of macrophage phenotype by cell shape. Proc Natl Acad Sci U S A. 110(43):172538.

Medzhitov, R. \& Horng, T. 2009. Transcriptional control of the inflammatory response. Nature Rev. Immunol. 9, 692-703.

Meloni-Bruneri L, Campa A, Abdalla D, Calich V, Burger E. 1996. Neutrophils from air-pouches of resistant mice to Paracoccidioides brasiliensis infection are more activated and efficient in killing the fungi than those of susceptible ones. $J$. Leukoc. Biol 59: 526-33

Meloni-Bruneri L, Campa A, Abdalla D, Calich V, Lenzi H, Burger E. 1996. Neutrophil oxidative metabolism and killing of P. brasiliensis after air pouch infection of susceptible and resistant mice. Journal of leukocyte biology 59: 52633

Mendes-Giannini MJ, Hanna SA, da Silva JL, Andreotti PF, Vincenzi LR, Benard G, Lenzi HL, Soares CP. 2004. Invasion of epithelial mammalian cells by Paracoccidioides brasiliensis leads to cytoskeletal rearrangement and apoptosis of the host cell. Microbes Infect 6: 882-91

Mendes-Giannini MJ, Monteiro da Silva JL, de Fatima da Silva J, Donofrio FC, Miranda ET, Andreotti PF, Soares CP. 2008. Interactions of Paracoccidioides brasiliensis with host cells: recent advances. Mycopathologia 165: 237-48

Menzin J, Meyers JL, Friedman M, Perfect JR, Langston AA, Danna RP, Papadopoulos G. 2009. Mortality, length of hospitalization, and costs associated with invasive fungal infections in high-risk patients. Am J Health Syst Pharm. $66: 1711-7$.

Misharin, A. V., Morales-Nebreda, L., Mutlu, G. M., Budinger, G. S., \& Perlman, H. (2013). Flow cytometric analysis of macrophages and dendritic cell subsets in the 
mouse lung. American journal of respiratory cell and molecular biology, 49(4), 503-510.

Moreira AP, Dias-Melicio LA, Soares AM. Interleukin-10 but not Transforming Growth Factor beta inhibits murine activated macrophages Paracoccidioides brasiliensis killing: effect on $\mathrm{H} 2 \mathrm{O} 2$ and NO production. Cell Immunol 2010; 263(2):196-203.

Morejón KML, Machado AA, Martinez R. Paracoccidioidomycosis in patients infected with and not infected with human immunodeficiency virus: a casecontrol study. Am J Trop Med Hyg 2009; 80:359-366.

Morgan M. 2011. An introduction to Rsamtools. ... . $a c$. jp/bioc/2.6/bioc/html/rsamtools. html. Acessado em ...

Möst J, Spötl L, Mayr G, Gasser A, Sarti A, Dierich MP. 1997. Formation of multinucleated giant cells in vitro is dependent on the stage of monocyte to macrophage maturation. Blood. 89(2):662-71.

Mortazavi A, Williams BA, McCue K, Schaeffer L, Wold B. 2008. Mapping and quantifying mammalian transcriptomes by RNA-Seq. Nat. Methods 5, 621-628.

Mullick A, Elias M, Picard S, Bourget L, Jovcevski O, Gauthier S, Tuite A, Harakidas P, Bihun C, Massie B, Gros P. 2004. Dysregulated inflammatory response to Candida albicans in a C5-deficient mouse strain. Infect Immun. 72(10):5868-76.

Murray PJ, Allen JE, Biswas SK, Fisher EA, Gilroy DW, Goerdt S, Gordon S, Hamilton JA, Ivashkiv LB, Lawrence T, Locati M, Mantovani A, Martinez FO, Mege JL, Mosser DM, Natoli G, Saeij JP, Schultze JL, Shirey KA, Sica A, Suttles J, Udalova I, van Ginderachter JA, Vogel SN, Wynn TA. 2014. Macrophage activation and polarization: nomenclature and experimental guidelines. Immunity. 17;41(1):14-20.

O'Connor BP, Danhorn T, De Arras L, Flatley BR, Marcus RA, Farias-Hesson E, Leach SM and Alper S. 2015. Regulation of toll-like receptor signaling by the SF3a mRNA splicing complex. PLoS Genet. 11(2):e1004932.

Oliveira AAd. 2010. Perfil transcricional do fungo Paracoccidioides na interação com célula pulmonares humanas (A549): análise comparativa entre $P$. brasiliensis (Pb18) e P. lutzii (Pb01). University of Brasilia (UnB), Brasilia-DF, Brasil

Ono MA, Bracarense AP, Morais HS, Trapp SM, Belitardo DR, Camargo ZP. 2001. Canine paracoccidioidomycosis: a seroepidemiologic study. Med Mycol 39: 27782

Oshlack A, Robinson MD, Young MD. 2010. From RNA-seq reads to differential expression results. Genome Biol 11: 220

Peraçoli M, Soares A, Mendes R, Marques S, Pereira P, Rezkallah-Iwasso M. 1991. Studies of natural killer cells in patients with paracoccidioidomycosis. Journal of 
medical and veterinary mycology : bi-monthly publication of the International Society for Human and Animal Mycology 29: 373-80

Perfect J. 2012. The impact of the host on fungal infections. The American Journal of Medicine Pina A, Bernardino S, Calich V. 2008. Alveolar macrophages from susceptible mice are more competent than those of resistant mice to control initial Paracoccidioides brasiliensis infection. Journal of leukocyte biology 83: 1088-99

Pina A, Bernardino S, Calich V. 2008. Alveolar macrophages from susceptible mice are more competent than those of resistant mice to control initial Paracoccidioides brasiliensis infection. Journal of leukocyte biology 83: 1088-99

Pina, A., de Araujo, E. F., Felonato, M., Loures, F. V., Feriotti, C., Bernardino, S., ... \& Calich, V. L. (2013). Myeloid dendritic cells (DCs) of mice susceptible to paracoccidioidomycosis suppress $\mathrm{T}$ cell responses whereas myeloid and plasmacytoid DCs from resistant mice induce effector and regulatory $\mathrm{T}$ cells. Infection and immunity, 81(4), 1064-1077.

Plato, A., Hardison, S. E., \& Brown, G. D. (2015, March). Pattern recognition receptors in antifungal immunity. In Seminars in immunopathology (Vol. 37, No. 2, pp. 97-106). Springer Berlin Heidelberg.

Prado M, Silva M, Laurenti R, Travassos L, Taborda C. 2009. Mortality due to systemic mycoses as a primary cause of death or in association with AIDS in Brazil: a review from 1996 to 2006. Memórias do Instituto Oswaldo Cruz 104: 513-21

Reales-Calderón JA, Aguilera-Montilla N, Corbí ÁL, Molero G, Gil C. (2014) Proteomic characterization of human proinflammatory M1 and anti-inflammatory M2 macrophages and their response to Candida albicans. Proteomics. 14(12):1503-18.

Restrepo A, McEwen JG, Castaneda E. 2001. The habitat of Paracoccidioides brasiliensis: how far from solving the riddle? Med Mycol 39: 233-41

Restrepo, A., Gómez, B. L., \& Tobón, A. (2012). Paracoccidioidomycosis: Latin America's own fungal disorder. Current Fungal Infection Reports, 6(4), 303-311.

Restrepo M, Ángela. (2014). El hábitat natural del hongo Paracoccidioides brasiliensis, ¿cómo trazar el límite entre lo rural y lo urbano?. Biomédica, 34(1), 5-6. Retrieved $\quad$ September 203, from http://www.scielo.org.co/scielo.php?script=sci_arttext\&pid=S0120$41572014000100001 \& \operatorname{lng}=$ en\&tlng=es. .

Rioja A, Pizzey AR, Marson CM, Thomas NS. 2000. Preferential induction of apoptosis of leukaemic cells by farnesol. FEBS Lett 467: 291-5

Rivera A. 2014. Protective immune responses to fungal infections. Parasite Immunol. 36(9): 453-62 
Robinson, M.D., McCarthy, D.J., Smyth, G.K., 2010. edgeR: a Bioconductor package for differential expression analysis of digital gene expression data. Bioinformatics 26, 139-140.

Roederer M. 2001. Spectral compensation for flow cytometry: visualization artifacts, limitations, and caveats. Cytometry 45: 194-205

Romani L. 2004. Immunity to fungal infections. Nat Rev Immunol 4: 1-23

Romani, L. (2011). Immunity to fungal infections. Nature Reviews Immunology, $11(4), 275-288$.

Romano-Keeler J, Weitkamp J-H, Moore D. 2012. Regulatory properties of the intestinal microbiome effecting the development and treatment of diabetes. Current opinion in endocrinology, diabetes, and obesity 19: 73-80

Roy René M, Klein Bruce S. 2012. Dendritic Cells in Antifungal Immunity and Vaccine Design. Cell Host \&amp; Microbe 11: 436-46

Saini J, Gupta A, Jolapara M, Chatterjee S, Pendharkar H, Chandreshekher K, Radhakrishnan V. 2010. Imaging findings in intracranial aspergillus infection in immunocompetent patients. World neurosurgery 74: 661-70

San-Blas F, Cova LJ. 1975. Growth curves of the yeast-like form of Paracocidioides bradiliensis. Sabouraudia 13 Pt 1: 22-9

San-Blas G. 1985. Paracoccidioides brasiliensis: cell wall glucans, pathogenicity, and dimorphism. Curr Top Med Mycol 1: 235-57

San-Blas G. 1993. Biochemical and physiological aspects in the dimorphism of Paracoccidioides brasiliensis. Arch Med Res 24: 267-8

San-Blas G, Nino-Vega G, Iturriaga T. 2002. Paracoccidioides brasiliensis and paracoccidioidomycosis: molecular approaches to morphogenesis, diagnosis, epidemiology, taxonomy and genetics. Med Mycol 40: 225-42

Sans-Fons, M.G., Yeramian, A., Pereira-Lopes, S., Santamarı'a-Babi, L.F., Modolell, M., Lloberas, J., and Celada, A. (2013). Arginine transport is impaired in C57Bl/6 mouse macrophages as a result of a deletion in the promoter of Slc7a2 (CAT2), and susceptibility to Leishmania infection is reduced. J. Infect. Dis. 207, 16841693.

Santos, E., \& Levitz, S. M. (2014). Fungal Vaccines and Immunotherapeutics. Cold Spring Harbor perspectives in medicine, 4(11), a019711.

Schmieder, R., Edwards, R., 2011. Quality control and preprocessing of metagenomic datasets. Bioinformatics 27, 863-864.

Schroeder, A., Mueller, O., Stocker, S., Salowsky, R., Leiber, M., Gassmann, M., ... \& Ragg, T. (2006). The RIN: an RNA integrity number for assigning integrity values to RNA measurements. BMC molecular biology, 7(1), 3. 
Searle, C. L., Ochs, J. H., Cáceres, C. E., Chiang, S. L., Gerardo, N. M., Hall, S. R., \& Duffy, M. A. (2015). Plasticity, not genetic variation, drives infection success of a fungal parasite. Parasitology, 142(06), 839-848.

Shankar, J., Restrepo, A., Clemons, K. V., \& Stevens, D. A. (2011). Hormones and the resistance of women to paracoccidioidomycosis. Clinical microbiology reviews, 24(2), 296-313.

Shendure J, Ji H. 2008. Next-generation DNA sequencing. Nat Biotechnol 26: $1135-$ 45

da Silva, M. B., Marques, A. F., Nosanchuk, J. D., Casadevall, A., Travassos, L. R., \& Taborda, C. P. (2006). Melanin in the dimorphic fungal pathogen Paracoccidioides brasiliensis: effects on phagocytosis, intracellular resistance and drug susceptibility. Microbes and Infection, 8(1), 197-205.

Silva SS, Tavares AH, Passos-Silva DG, Fachin AL, Teixeira SM, Soares CM, Carvalho MJ, Bocca AL, Silva-Pereira I, Passos GA, Felipe MS. 2008. Transcriptional response of murine macrophages upon infection with opsonized Paracoccidioides brasiliensis yeast cells. Microbes Infect 10: 12-20

Smith JA, Kauffman CA. 2010. Blastomycosis. Proc Am Thorac Soc 7: 173-180.

Sierra-Filardi, E., Nieto, C., Domínguez-Soto, Á., Barroso, R., Sánchez-Mateos, P., Puig-Kroger, A., ... \& Corbí, Á. L. (2014). CCL2 shapes macrophage polarization by GM-CSF and M-CSF: identification of CCL2/CCR2-dependent gene expression profile. The Journal of Immunology, 192(8), 3858-3867.

Singer-Vermes, L., Burger, E., Franco, M., Moscar Di-Bacchi, M., Mendes-Giannini, M., Calich, V., 1989. Evaluation of the pathogenicity and immunogenicity of seven Paracoccidioides brasiliensis isolates in susceptible inbred mice. Medical Mycology 27, 71-82.

Singer-Vermes LM, Caldeira CB, Burger E, Calich LG. 1993. Experimental murine paracoccidioidomycosis: relationship among the dissemination of the infection, humoral and cellular immune responses. Clin Exp Immunol 94: 75-9

Singer-Vermes LM, Sakamoto TN, Vaz CA, Calich VL. 1995. Influence of the genetic pattern and sex of mice in experimental paracoccidioidomycosis. Clin Exp Immunol 101: 114-20

Singer-Vermes LM, Burger E, Calich VL, Modesto-Xavier LH, Sakamoto TN, Sugizaki MF, Meira DA, Mendes RP. 1994. Pathogenicity and immunogenicity of Paracoccidioides brasiliensis isolates in the human disease and in an experimental murine model. Clin Exp Immunol 97: 113-9

Siqueira KZ, Campos Soares AM, Dias-Melicio LA et al. Interleukin-6 treatment enhances human monocyte permissiveness for Paracoccidioides brasiliensis growth by modulating cytokine production. Med Mycol 2009; 47(3):259-267

Spadari K, Lopes JD, Rogério S. 2004. Down-regulation of dendritic cell activation induced by Paracoccidioides brasiliensis. Immunology Letters 94: 107-14 
Spadari K, Ramalho K, Russo M, Rogério S. 2007. Interaction between Paracoccidioides brasiliensis and Pulmonary Dendritic Cells Induces Interleukin10 Production and Toll-Like Receptor-2 Expression: Possible Mechanisms of Susceptibility. . Journal of Infectious Disease 196: 1108-15

Spandidos A, Wang X, Wang H, Seed B. 2010. PrimerBank: a resource of human and mouse PCR primer pairs for gene expression detection and quantification. Nucleic acids research 38: 9

Spor A, Koren O, Ley R. 2011. Unravelling the effects of the environment and host genotype on the gut microbiome. Nature reviews. Microbiology 9: 279-90

Staudt LM, Brown PO. 2000. Genomic views of the immune system*. Annu Rev Immunol 18: 829-59

Stout and Suttles. 2004. Functional plasticity of macrophages: reversible adaptation to changing microenvironments. J Leukoc Biol. 76(3):509-13. Epub 2004 Jun 24. Review.

Sultan M, Schulz MH, Richard H, Magen A, Klingenhoff A, Scherf M, Seifert M, Borodina T, Soldatov A, Parkhomchuk D, Schmidt D, O'Keeffe S, Haas S, Vingron M, Lehrach H, Yaspo ML. 2008. A global view of gene activity and alternative splicing by deep sequencing of the human transcriptome. Science 321: 956-60

Tadokoro CE, de Almeida Abrahamsohn I.2001. Bone marrow-derived macrophages grown in GM-CSF or M-CSF differ in their ability to produce IL-12 and to induce IFN-gamma production after stimulation with Trypanosoma cruzi antigens. Immunol Lett. 77(1):31-8.

Tavares A, Derengowski L, Ferreira K, Silva S, Macedo C, Bocca A, Passos G, Almeida S, Silva-Pereira I. 2012. Murine dendritic cells transcriptional modulation upon Paracoccidioides brasiliensis infection. PLoS neglected tropical diseases 6

Tavares AH, Magalhães KG, Almeida RD, Correa R, Burgel PH, Bocca AL. 2013. NLRP3 inflammasome activation by Paracoccidioides brasiliensis. PLoS Negl Trop Dis. 7(12):e2595.

Taschuk R, Griebel P. 2012. Commensal microbiome effects on mucosal immune system development in the ruminant gastrointestinal tract. Animal health research reviews / Conference of Research Workers in Animal Diseases 13: 129-41

Teixeira, M. M., Theodoro, R. C., de Carvalho, M. J., Fernandes, L., Paes, H. C., Hahn, R. C., ... \& Felipe, M. S. S. (2009). Phylogenetic analysis reveals a high level of speciation in the Paracoccidioides genus. Molecular phylogenetics and evolution, 52(2), 273-283.

Tercarioli GR, Bagagli E, Reis GM, Theodoro RC, Bosco Sde M, Macoris SA, Richini-Pereira VB. 2007. Ecological study of Paracoccidioides brasiliensis in 
soil: growth ability, conidia production and molecular detection. BMC Microbiol 7: 92

Thind, S. K., Taborda, C. P., \& Nosanchuk, J. D. (2015). Dendritic cell interactions with Histoplasma and Paracoccidioides. Virulence, (ahead-of-print), 6-14.

Thorpe J, Ahmed I, Hind R. 2004. Intestinal perforation with invasive candidiasis in an immunocompetent adult. Journal of the College of Physicians and Surgeons-Pakistan : JCPSP 14: 187-8

Verma, A., Wüthrich, M., Deepe, G., \& Klein, B. (2014). Adaptive Immunity to Fungi. Cold Spring Harbor perspectives in medicine, a019612.

Verreck, F. A., T. de Boer, D. M. Langenberg, M. A. Hoeve, M. Kramer, E. Vaisberg, R. Kastelein, A. Kolk, R. de Waal-Malefyt, and T. H. Ottenhoff. 2004. Human IL-23-producing type 1 macrophages promote but IL-10-producing type 2 macrophages subvert immunity to (myco)bacteria. Proc. Natl. Acad. Sci. USA 101: 4560-4565.

Wan H, Dupasquier M. 2005. Dendritic cells in vivo and in vitro. Cell Mol Immunol 2: $28-35$

Wang Z, Gerstein M, Snyder M. 2009. RNA-Seq: a revolutionary tool for transcriptomics. Nat Rev Genet 10: 57-63

Wanke B, Londero AT. Epidemiology and paracoccidioidomycosis infection. In: Franco M, Lacaz CS, Restrepo-Moreno A, Del Negro G, editors. Paracoccidioidomycosis. Boca Raton: CRC Press; 1994. p. 109-120.

Wanke, B., \& Aidê, M. A. (2009). Capítulo 6-Paracoccidioidomicose. J. Bras. Pneumol, 35(12), 1245-1249.

Wevers BA, Geijtenbeek TB, Gringhuis SI. 2013. C-type lectin receptors orchestrate antifungal immunity. Future Microbiol. 8(7):839-54

Wüthrich M, Wang H, Li M, Lerksuthirat T, Hardison SE, Brown GD, Klein B. 2015. $F$. pedrosoi-induced Th17-cell differentiation in mice is fostered by Dectin-2 and suppressed by Mincle recognition. Eur J Immunol. doi: 10.1002/eji.201545591.

Yowe D, Cook WJ, Gutierrez-Ramos JC. 2001. Microarrays for studying the host transcriptional response to microbial infection and for the identification of host drug targets. Microbes Infect 3: 813-21

Zak D, Aderem A. 2009. Systems biology of innate immunity. Immunological reviews 227: 264-82

Zeidberg LD, Ajello L, Dillon A, Runyon LC. 1952. Isolation of histoplasma capsulatum from soil. Am J Public Health Nations Health 42: 930-5

Zhang P, Sandland GJ, Feng Z, Xu D, Minchella DJ. 2007. Evolutionary implications for interactions between multiple strains of host and parasite. J Theor Biol 248: $225-40$

Zheng XF, Hong YX, Feng GJ, Zhang GF, Rogers H, Lewis MA, Williams DW, Xia ZF, Song B, Wei XQ (2013) Lipopolysaccharide-induced M2 to M1 macrophage 
transformation for IL-12p70 production is blocked by Candida albicans mediated up-regulation of EBI3 expression. PLoS One. 27; 8(5):e63967. 
ANEXO 
Universidade de Brasília Instituto de Ciências Biológicas
Comitê de Ética no Uso Animal

Brasília, 10 de setembro de 2012 .

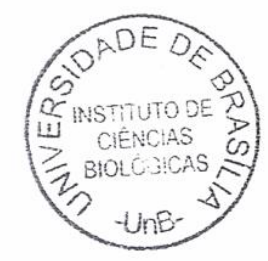

\section{DECLARAÇÃO}

Declaramos que o projeto intitulado "CARACTERIZAÇão dAS baSeS MOleCUlares da SUSCETIBILIDAde IMUNOLÓGICA À INFECÇÃo SISTÊMICA.", UnBDOC n.o 52657/2011, sob responsabilidade da Profa. Ildinete Silva Pereira foi avaliado e aprovado pela Comissão de Ética no Uso Animal (CEUA) do Instituto de Ciências Biológicas da Universidade de Brasília.
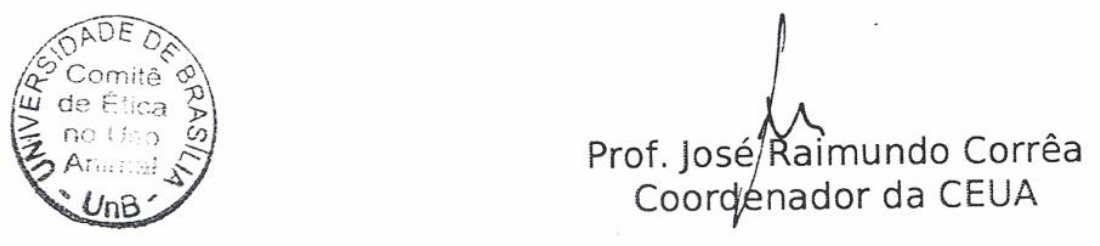
APÊNDICE 